\title{
FORMAÇÃO DE PROFESSORES, CURRÍCULO E PRÁtICAS PEDAGÓGICAS NO MUNICÍPIO DE AQUIRAZ
}

\section{ARTIGO ORIGINAL}

ARAÚJO, Marciano Vieira de ${ }^{1}$

BARROS, Delma ${ }^{2}$

ARAÚJO, Marciano Vieira de. BARROS, Delma. Formação de professores, currículo e práticas pedagógicas no município de Aquiraz. Revista Científica Multidisciplinar Núcleo do Conhecimento. Ano 04, Ed. 05, Vol. 06, pp. 56-201. Maio de 2019. ISSN: 2448-0959

\section{RESUMO}

O papel do professor na dimensão educacional é pautado por grandes responsabilidades sociais as quais thes são requisitadas determinadas funções, e para agirem, de modo consciente, autônomo e crítico, necessitam de conhecimentos. Esse processo é contínuo e se constitui em diferentes fases/etapas formativas de maneira singular e coletiva, formando a identidade docente. Nosso foco neste estudo foi resolver a problemática: Que conhecimentos os professores constroem em um processo de formação continuada, no momento da elaboração e implementação de um projeto curricular? O que é currículo e práticas pedagógicas? Destacamos como

\footnotetext{
${ }^{1}$ Mestrando em Educação pela Universidade Anne Sullivan; Especialista em Ensino de História e Geografia pela Faculdade Stella Maris; Especializado em Psicopedagogia Clínica Institucional pela Universidade Estadual Vale do Acaraú; Pós Graduação em Educação Especial e Inclusiva e Neuropsicopedacogia; e Pós Graduação em Docência no Ensino Superior e Psicomotricidade, ambas pela FAVENI - Faculdade Venda Nova do Imigrante. Graduado- Licenciatura em Pedagogia pela Universidade Estadual Vale do Acaraú.

${ }^{2}$ Mestre em Ciência da Educação.
} 
objetivo principal identificar e analisar os conhecimentos que o professor constrói em um processo de formação continuada e como estes repercutem na sua ação pedagógica. O grupo de informantes foi composto por professores de Educação infantil e fundamental, que participam do processo de formação continuada implementado pela Secretaria Municipal de Educação de Aquiraz. Os professores envolvidos participando Projeto de formação de professores, ministradas pelos professores que estão como técnicos na Secretaria de Educação, as formações são baseadas nos currículos do Sistema Educacional que atuam nas 43 escolas do município de Aquiraz. A metodologia de pesquisa foi norteada pela teoria crítica, com uma abordagem participativa, com a vinculação de diferentes procedimentos de coleta de informações, sendo eles: questionário, observação das aulas e entrevista feita pelo pesquisador aos professores do referido município. Como resultado das análises das informações concluímos que a formação continuada tenta cumprir suas metas e atingir os objetivos traçados, pois relacionam e mobilizam a realidade dos professores, e que, ao ter o currículo como referência, fazem com que seus conhecimentos se direcionem para além da especificidade de ensino. A análise dos resultados deixa evidente que, no grupo em pauta, existe uma evolução singular em cada ação docente. Entendemos que com divulgação dos resultados, poderemos contribuir na avaliação do projeto de formação continuada e implementação do currículo e melhorias das práticas pedagógicas, na efetivação dessas no Projeto Pedagógico em desenvolvimento nas escolas do citado município. Portanto, se trata de pesquisa quantitativa, documental com base nos dados coletados no campo de pesquisa tendo como objeto as formações de professores ministradas no município de Aquiraz.

Palavras-chave: Formação de professores, educação, construção curricular, conhecimentos docentes.

\section{INTRODUÇÃO}

Sabemos que a formação docente está numa perspectiva inacabada, pois, o processo educativo é evolutivo e sua construção é caracterizada conforme a trajetória histórica do educador, pautados no que dizem Pacheco e Flores (1999), eles apontam as fases que constituem a formação docente da seguinte maneira: 
- Pré-formação;

- Formação inicial;

- Iniciação;

- Formação permanente.

Queremos considerar como foco de nossa pesquisa a formação permanentemente continuada dos professores pautada nos currículos e suas práticas pedagógicas, levantaremos assim, alguns questionamentos:

- Por que os professores mostram insatisfação ao participar das formações de professores no município de Aquiraz? Já que elas trazem tantas informações.

- Que conhecimentos os professores constroem em um processo de formação continuada, no momento da elaboração e implementação de um projeto curricular?

Percebemos que como de costume, pois, não acontece só em Aquiraz, professores resistem em participar de formações continuadas, e, por esses e outros motivos, despertamos interesse para uma investigação sobre a importância da formação de professores, currículo e didáticas pedagógicas e tentar sanar junto aos colegas professores a problemática, mostrando para eles que é essencial nossa participação nas formações.

Ao refletirmos e procurarmos fatos comprovatório da importância das formações, encontramos várias referências, nesse sentido, vieram várias indagações, essas serão amplamente investigadas e respondidas posteriormente, pois, compreendemos que as formações de professores, trazem informações que nos engrandecem. Sendo assim, indagamos:

- Que saberes se constrói nas formações, quais suas origens?

- De que forma os docentes se apropriam dos saberes e os transformam em conhecimentos?

- Como os saberes podem ser articulados na prática pedagógica?

- Quais saberes são oriundos do próprio fazer docente? 
- Será que os docentes conhecem profundamente os currículos?

- Onde os currículos são utilizados pelos docentes?

Esses questionamentos serão respondidos posteriormente e serão pautados em teóricos que são reconhecidos por estudos no tocante a formação de professores, como por exemplo: Pimenta (1994-2010), Silva (2009), Moreira(1996), Marre (1991),entre outros e documentos oficiais como: LDB, CF, PNE, definindo o que é currículo e didáticas pedagógicas e qual sua importância. Vejamos o pensamento de Pimenta (2002), sobre atividade e prática docente, ele retrata que:

Uma das demandas importantes dos anos noventa, em relação a atividade docente, é, justamente, repensar a formação inicial e continuada dos professores, a partir da análise das práticas pedagógicas docentes, ou seja, do cotidiano escolar. (PIMENTA, 2002, p. 45)

Constatamos no pensamento do citado autor que há uma permanente necessidade de reformulação do cotidiano escolar, na contemporaneidade são grandes os desafios apresentados em qualquer atividade profissional docente que, na atualidade, ultrapassa a pratica de aplicar uma teoria aprendida ou mesmo repetir procedimentos metodológicos, causa maior de se receber constantes formações para qualificação do sistema educacional.

No município de Aquiraz, as formações são ministradas por docentes da Secretaria de Educação, nelas, eles professores, colocam a importância do conhecimento do currículo para melhoria da pratica docente e escolha da didática a ser aplicada com os educandos matriculados na rede municipal de ensino, num total de 42 escolas, sendo uma na sede e as demais nos distritos pertencentes ao município supracitado.

Encontramos no pensamento de Moreira e Silva (1995) fundamentação para a colocação acima. Eles enfatizam que o currículo é transmissor de conhecimentos e especificidade na organização da sociedade e da educação. Vejamos a citação:

O currículo não é um elemento inocente e neutro de transmissão desinteressada do conhecimento social. O currículo está implicado em 
relações de poder, o currículo transmite visões sociais particulares e interessadas, o currículo produz identidades individuais e sociais particulares. O currículo não é um elemento transcendente e atemporal - ele tem uma história, vinculada a formas específicas e contingentes de organização da sociedade e da educação. (MOREIRA; SILVA, 1995, p. 7-8):

Ao levantamos a problemática da resistência dos docentes na participação das formações de professores, e nossa pesquisa se aprofundou em busca de fatores que a justificasse, pois, segundo Marre (1991), "quando escolhemos um tema para pesquisa, este deve estar relacionado a interesses de uma pesquisa que tenha referência com o pesquisador". Por isso é fundamental termos conhecimentos das formações, currículo e prática pedagógica, objeto de pesquisa.

É notório que as formações trazem conhecimentos e benefícios para uma prática pedagógica consciente e qualificada dos colegas docentes que delas venham participar, através das informações adquiridas, com certeza, os discentes das escolas públicas do município de Aquiraz receberão uma sistemática de ensino qualificada que os desenvolverão em todos os sentidos. Portanto, fundamentaremos nosso pensamento no autor agora mencionado: Marre (1991) diz que:

Não se pode dizer que se faz uma escolha neutra; pelo contrário se faz porque está relacionada com um sistema de valores com as convicções últimas do sujeito que escolhe (MARRE, 1991, p. 10).

A citação desse autor nos leva a compreender que escolhemos um tema pertinente e para compreensão de nossa pesquisa a dividimos em capítulos, neles queremos mostrar fatores históricos que mostrem definições de currículo e práticas pedagógicas associados às formações de professores, já que são tão importantes para o desenvolvimento dos profissionais da educação e os descrevemos a seguir.

Nossa pesquisa relatará no primeiro capítulo a inserção histórica da educação na escola com a história da educação no Brasil, nele falaremos também do paradigma 
educacional e o sistema escolar, suas tendências e as abordagens pedagógicas detalhadamente os pressupostos teóricos com pesquisadores que abordam o tema pesquisado e os documentos oficiais que tratam da educação como fator fundamental de transformação de uma sociedade e para que ela aconteça qualificadamente são necessárias permanentes formações para os docentes.

No segundo capítulo, retrataremos a formação docente no Brasil com sua constituição histórica e os conhecimentos abordados na formação docente, queremos mostrar também as fases do percurso formativos do docente e a formação permanente continuada dando experiência a quem vai aderir a profissão de docente.

Com certeza, as formações de professores são fundamentais para uma pratica docente inovadora, e os profissionais da educação devem estar a todo momento se qualificando e por esse motivo é que queremos aprofundar nossos conhecimentos sobre $o$ assunto e assim estarmos respaldados para uma investigação cientifica sobre o tema e levarmos aos colegas da rede municipal de Aquiraz, informações que os auxiliem a ministrarem aulas prazerosas.

Nossa pesquisa tem como foco: Currículo como construção, implementação e avaliação nas teorias e desenvolvimento curricular, referenciaremos a organização curricular no Brasil e os modelos curriculares, educação e a organização curricular e ainda a avaliação do currículo e a formação continuada, esses temas e subtemas serão ressaltados no terceiro capítulo.

Com certeza após as leituras, e reflexões dos temas, nos tornaremos conscientes da importância de um grupo docente receber formação para engrandecimentos de sua prática pedagógica e desenvolvimento de seus educandos qualificadamente e assim, sejam inseridos no mercado de trabalho tão seletivo de nossa sociedade que exige cumprimento de direitos e deveres.

Para concluirmos, colocaremos a parte mais importante de nossa pesquisa cientifica, a investigação fundamentada nos questionários aplicados nos ambientes escolares, esses foram sistematizados e serão tabeladas as respostas dos colegas docentes 
sobre as formações de professores, sua importância e a participação e acima de tudo, sobre os benefícios de recebê-las.

Assim, definimos nossa pesquisa como quantitativa e documental onde buscamos resultados que possam ser quantificadas pelo meio da coleta de dados sem instrumentos formais e estruturados de maneira mais organizada e intuitiva com uma metodologia de aplicação de questionários abordando o objeto de pesquisa. Para finalizar descreveremos nossas considerações finais, as referências e os anexos.

\section{CAPÍTULO}

\section{INSERÇÃO HISTÓRICA DA EDUCAÇÃO DO BRASIL}

Sabemos que a educação traz como destaque a atuação do professor, esse profissional transmite conhecimentos por meio de mecanismos de flexibilização da diversidade existente no processo de ensino-aprendizagem, no qual é necessário haver uma integração de conhecimentos, uma preparação com a formação acadêmica, ética, ampliação da qualidade e capacidade para o exercício da educação no Brasil desde o período colonial até os dias atuais.

A partir desse tópico, apresentaremos a inserção da Educação no ambiente escolar, apontaremos também, os objetivos empregados e o perfil profissional do professor perante as funções que lhes são exigidas a cada momento histórico que o sistema educacional passa.

Caracterizaremos nesse tópico, as teorias educacionais que mais exerceram influências na ação dos professores, e atualmente o que vem sendo proposto para o processo de ensino-aprendizagem. Destacaremos a relevância que esteja incluída ao PPP da escola como responsável pelo ensino de conhecimentos, mas, esse é assunto do segundo capítulo.

Vamos iniciar colocando a trajetória da Educação no Brasil. Desde que o ensino e a aprendizagem passaram a ser planejados e formalizados, eles sofreram muitas transformações. Contaremos essa trajetória da educação a partir da chegada dos 
portugueses e as principais características de cada período histórico. Delinearemos também os fatos marcantes desses períodos e os pensadores que embasaram o ensino em mais de cinco séculos.

Segundo Gisela Waiskop (2013), a história da educação se passa num contexto, é como um tripé, autora, diretora do Instituto Singularidades, ressalta a trajetória da Educação na perspectiva de percurso de um passado ao presente, com desafios do docente no processo de ensino-aprendizagem, a autora diz que:

Devemos olhar para a história da Educação pelo tripé de quem faz, no caso o homem, o contexto e o produto, o que foi feito, sempre com a perspectiva de entender o presente (WAISKOP, 2013, p. 13).

Todo docente em sua formação deverá compreender a trajetória da Educação, essa é a parte principal de uma profissão de transmissão de conhecimento é o que constatamos na citação acima colocada e fundamentado por Dermeval Saviani, ele professor emérito da Universidade Estadual de Campinas (UNICAMP), sugere que essa área do conhecimento seja eixo da organização dos conteúdos curriculares de pedagogia.

Saviani ao falar do curso de formação docente, ressalta que no século XIX, a burguesia, ou seja, a classe dominante estruturava os sistemas nacionais de ensino e advogar a escolarização, o autor diz que:

Na sociedade do século XIX, escolarizar para que os homens se tornassem cidadãos politizados para viver a democracia. Segundo esse autor: De um curso assim estruturado se espera que forme pedagogos com uma aguda consciência da realidade em que vão atuar (SAVIANI, 2007, p. 23).

Apesar da trajetória da educação ser de grande importância para o docente, esse conhecimento não tem recebido a devida atenção, o que vemos, segundo a professora Maria Helena Câmara Bastos, atuando na Universidade Católica do Rio 
Grande do Sul (PUC-RS), ela diz que: "hoje temos uma memória de esquecimento e o que é velho não é considerado relevante" (BASTOS, 2013, p. 26).

A Trajetória da Educação, desde os primórdios dos tempos, era vista como transformação de um povo e relação entre passado e presente, ao colocarmos as citações acima vemos isso, mas, vamos ver o que Platão (427-347 a. C), propunha: "É fundamental que todos conheçam a história e entendam que ela é feita por nós a cada dia. Caso contrário, nossa identidade não se constrói".

Após as citações, colocaremos no próximo tópico a história da educação nos vários períodos históricos, a figura abaixo mostra como começou a educação no Brasil, com os padres jesuítas tendo o objetivo de catequizar os índios, eles tinham como objetivo catequizar os índios. Nosso primeiro modelo de educação.

Figura 01: Padres Jesuítas Catequizando índios

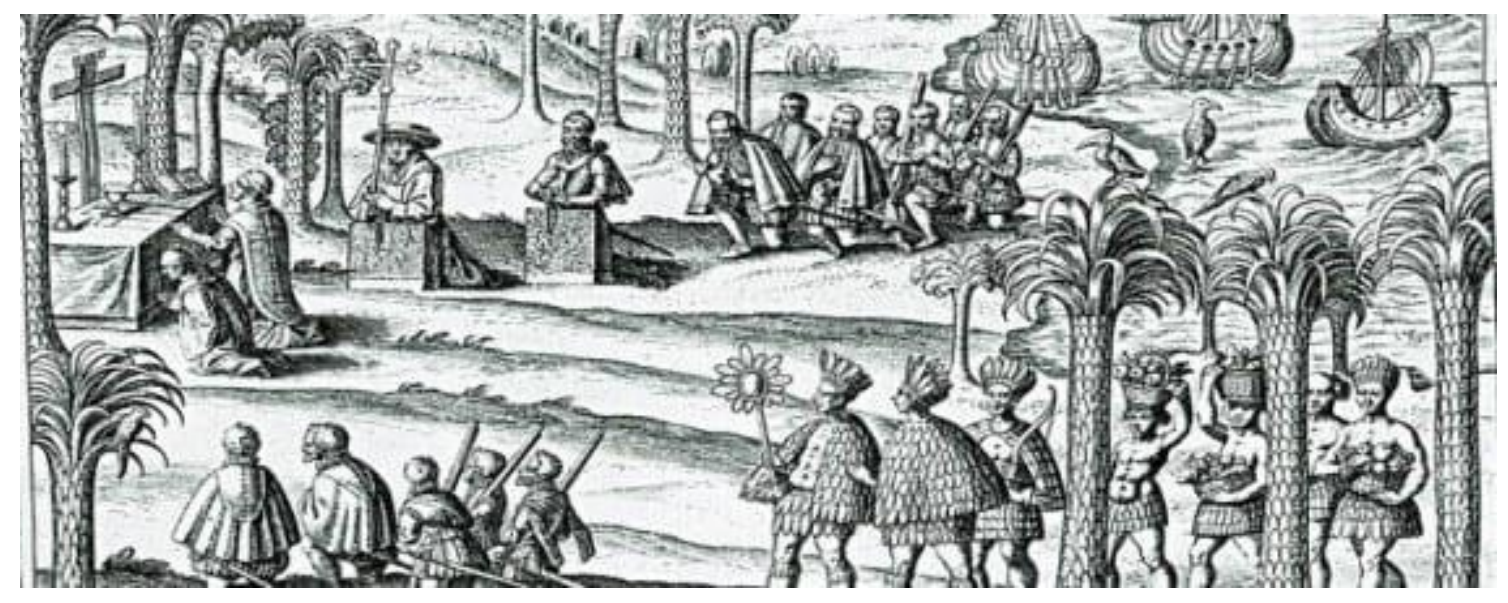

Fonte: Imagem do Livro "História da Educação" (1989)

"Os padres começaram a catequizar os Índios, logo que desembarcaram no Brasil"

\section{HISTÓRIA DA EDUCAÇÃO NO BRASIL}

Ao começarmos a história da Educação brasileira, percebemos através das leituras realizadas que ela é constituída por diferentes formas de entendimento, isso acontece por causa dos interesses políticos, econômicos e a respectiva ideologia dominante, 
sendo retratada na prática pedagógica do docente no território brasileiro. Segundo Soares (1992), a educação é necessária socialmente em diferentes períodos históricos. Vejamos o pensamento desse renomado autor:

"[...] sendo a Educação uma prática pedagógica ela surge de necessidades sociais concretas que, identificadas em diferentes momentos históricos, dão origem a diferentes entendimentos do que ela conhece". (SOARES, et al 1992, p. 50)

A História da Educação no Brasil teve início no período colonial, quando começaram as primeiras relações entre Estado e Educação, através dos padres jesuítas. A história mostra que inicialmente os filhos dos índios eram os favorecidos com a educação dos padres, depois, foram os órfãos portugueses, mais tarde, os filhos dos proprietários das fazendas de gado e dos engenhos de cana de açúcar e dos escravos.

Mas, infelizmente, nossa educação começou com exclusão, pois, apenas os meninos poderiam receber as lições dos jesuítas, esses foram os primeiros alunos da Educação Formal e letrada brasileira e os padres jesuítas os primeiros professores do Brasil.

Daremos a partir daqui as informações de cada período histórico sobre a educação no Brasil, seus progressos e retrocessos e a importância das formações de docentes para o desenvolvimento social e educacional da população brasileira, tiramos todas as informações aqui colocadas de Livros e Documentos de História. 
Figura 02: Marques de Pombal

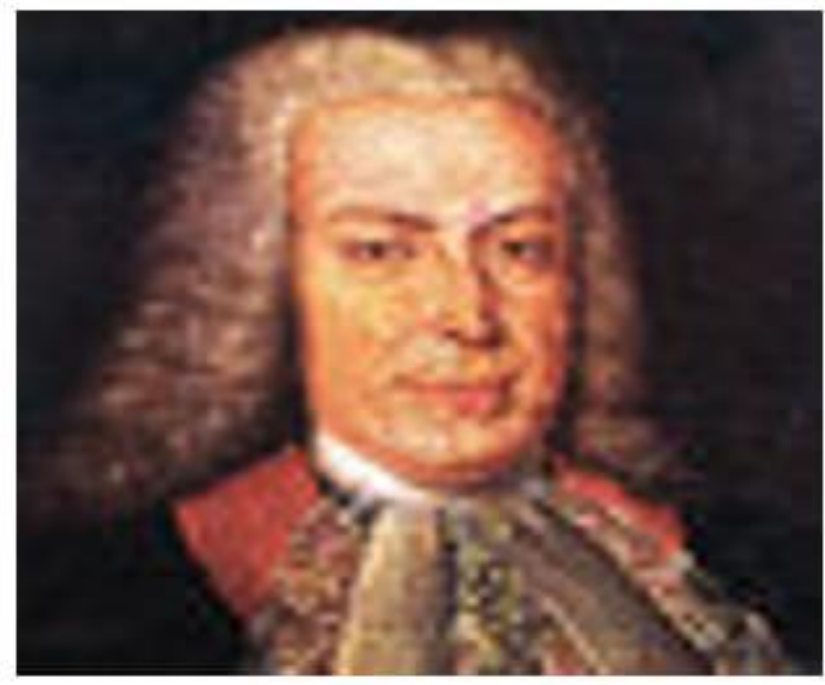

Fonte: Tirada do livro História da Educação Brasileira (2009 2ª Ed.)

Foto do Marques de Pombal, ele criou as Aulas Régias, mas, demorou a organizar seção de professores.

\section{PERÍODO COLONIAL}

Podemos certificar que a educação no Brasil como Processo sistematizado de transmissão de conhecimentos, não pode estar separado da história da Companhia de Jesus. O marco desse período, foram as negociações de Dom João III, com essa ordem missionária católica.

Nesse período, acontecia a exploração inicial e os esforços educacionais foram dirigidos aos indígenas, submetidos à chamada "catequese" promovida pelos missionários jesuítas. O primórdio da educação nacional foi baseado no Ratio Studiorum ou Plano de Estudos - em 1549 comandada pela ordem religiosa católica chamada Companhia de Jesus, fundada por Inácio de Loyola, em 1534 retratada no parágrafo anterior. 
Se passaram duzentos e dez anos, no ano de 1759, os jesuítas foram expulsos, vieram as reformas pombalinas, com elas passou a ser instituído o ensino laico e público através das Aulas Regias onde os conteúdos tinham como base as Cartas Regias. Durante os anos de 1750 a 1777, foi implantado o ensino público no Brasil, mas, as escolas mantiveram o Ensino Religioso.

No ano de 1798, o bispo Azeredo Coutinho inspirado nas ideias iluministas que aprendera como aluno na Universidade de Coimbra, promove um seminário na cidade de Olinda. O Marques de Pombal, nesse período Primeiro Ministro de Portugal, defendia ideias do despotismo esclarecido e arduamente defendeu a Reforma Educacional Pombalina.

Passaram-se quase 30 anos sem mudanças da história do Brasil, no panorama educacional. A população do período colonial formada além dos nativos e dos colonizadores brancos, tivera o acréscimo da numerosa mão de obra escrava oriunda da África.

Mas os escravos negros não conseguiram qualquer direito à educação e os homens brancos estudavam nos colégios religiosos ou iam para a Europa. Triste situação educacional do Brasil, pois, apenas os mulatos procuravam a escola, em 1689, os colégios de jesuítas negavam matriculas aos mestiços, mas, tiveram que ceder, pois, só receberiam subsídios como "escolas públicas" se os recebessem, essa questão foi taxada de "questão dos pardos". Na figura abaixo mostra os padres jesuítas dando aula de catecismo 
Figura 03: Aula de Catecismo dos Padres Jesuítas

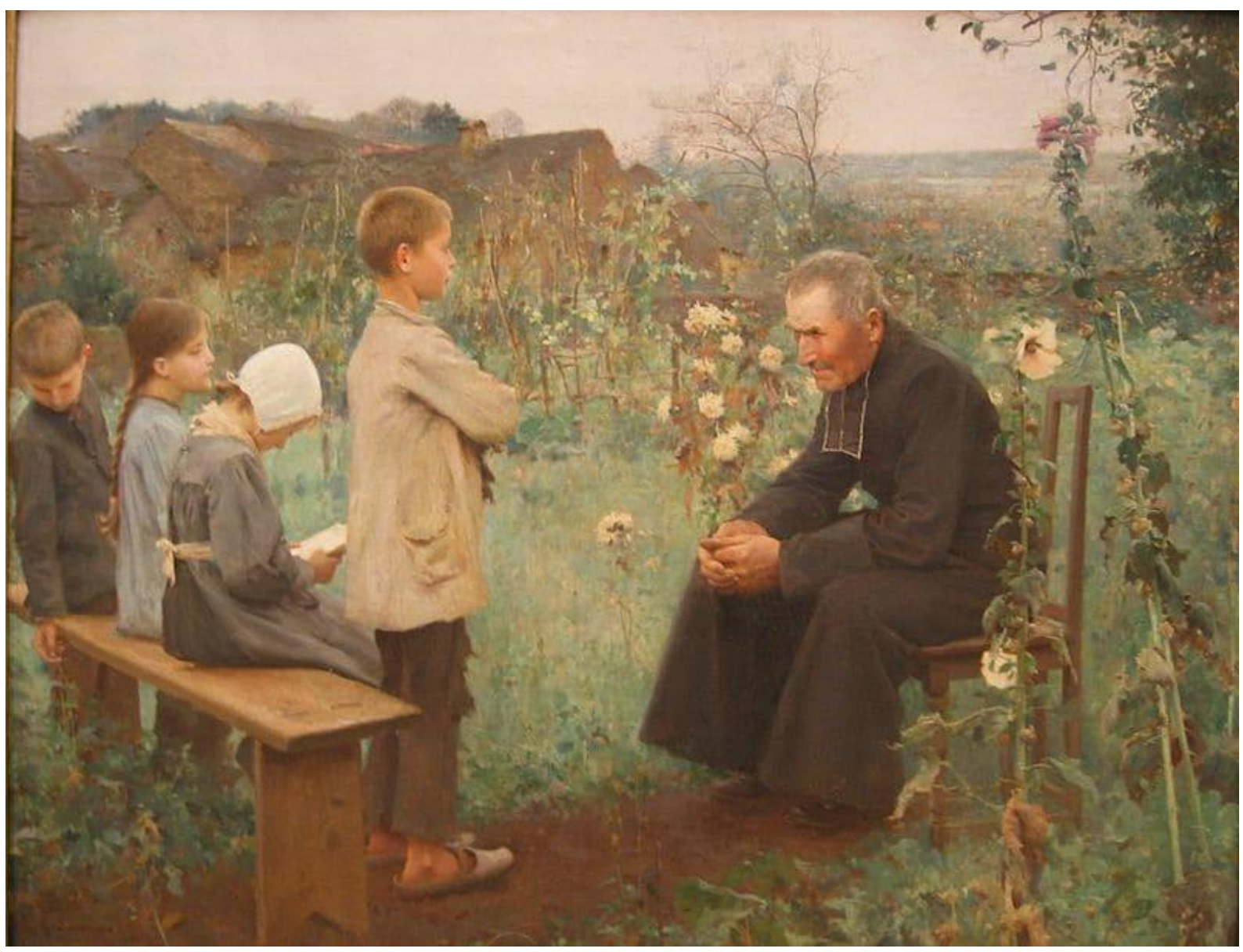

Fonte: Imagem do: "Quadro La lecon de cathéchismi"

"As Lições de Catecismo" (1890) Quadro de autoria de Jules-Alexis Muenier e encontra-se no Museu de Belas-Artes de Besançon

Para o Brasil, a expulsão dos jesuítas significou, entre outras coisas, a destruição do único sistema de ensino existente no país. Para Fernando de Azevedo, foi "a primeira grande e desastrosa reforma de ensino no Brasil". Como bem colocou Niskier (2001), vejamos a citação desse autor e depois o período da vinda da Família Real, outro período histórico:

A organicidade da educação jesuítica foi consagrada quando Pombal os expulsou levando o ensino brasileiro ao caos, através de suas famosas 'aulas régias', a despeito da existência de escolas fundadas por outras 
ordens religiosas, como os Beneditinos, os franciscanos e os Carmelitas. (NISKIER, 2001, p. 34)

O período colonial como descrito anteriormente, tem como marca principal, falando em educação "A Companhia de Jesus" que tinha como papel principal na sociedade brasileira, propiciar as condições necessárias para educar os grupos sociais menos favorecidos da população.

O ensino jesuítico, no início de suas atividades, não era um ensino para todos e sim para uma pequena parte da população, justificada essa exclusão, segundo os jesuítas, se destinava a educação exclusivamente para os "ignorantes", eles deveriam ler e escrever.

Sobre os jesuítas, Sertão (1980) e Vasconcelos (1977) consideraram a Companhia de Jesus, em sua história, era cheia de circunstâncias de ambiguidades, esses autores, ressaltam que uns louvam a atitude deles de catequizá-los, outros os chamam de falsificadores da fé, vejamos o pensamento dos autores:

Nenhuma instituição humana há sido julgada com mais parcialidade do que a dos jesuítas: para uns foram eles a idealização do poder católico, o tipo mais perfeito do ministro do Evangelho, numa palavra verdadeiros apóstolos, como em sua aparição, os denominou o povo; para outros simboliza o instituto de Loyola a falsificação da fé, o relaxamento das máximas da moral cristã, a corrupção da disciplina eclesiástica, quando exigiam-no os interesses de sua egoísta política (VASCONCELOS, 1977, p. 40).

Para Ribeiro (1998), o início de nossa educação aconteceu com os jesuítas, esse autor ressalta a importância da Companhia de Jesus, bem ou mal foram eles que deram os primeiros ensinamentos ao povo que aqui se encontravam na chegada dos colonizadores portugueses. $O$ autor ressalta que:

A vinda dos padres jesuítas, em 1549, não só marca o início da história da educação no Brasil, mas inaugura a primeira fase, a mais longa dessa 
história, e, certamente a mais importante pelo vulto da obra realizada e sobretudo pelas consequências que dela resultaram para nossa cultura e civilização. (RIBEIRO, 1998, p. 28)

Essa citação nos fala da importância dos jesuítas na época para o início da história da educação no Brasil, no ano de 1772, foi criado um subsídio literário onde diversos produtos ao serem comercializados era cobrado imposto, com a arrecadação desses impostos era utilizada para financiar o ensino primário e médio nas terras portuguesas.

O período colonial teve um saldo para a educação brasileira com a gestão do Marques de Pombal, esse foi o mais trágico possível, pois ele eliminou o sistema organizado feito pelos jesuítas e fez com que no início do século XIX a educação brasileira fosse praticamente inexistente, com práticas inadequadas e estagnadas sendo oferecidas aos pequenos brasileiros dessa época histórica.

Ressaltamos que o verdadeiro caos educacional do período histórico colonial é modificado em 1808, quando a Família Real Portuguesa chega ao Brasil.

Para atender às necessidades da realeza, o imperador D. João VI criou uma verdadeira estrutura educacional com escolas de medicina, bibliotecas, imprensa e academias militares, todos esses fatos serão contados no tópico seguinte para que entendamos o pensamento do imperador.

As Cartas Jesuíticas são documentos apresentados sob a forma de cartas escritas pelos padres jesuítas e que tinham como objetivo fornecer um relato das atividades desenvolvidas pela Companhia nas terras descobertas.

\section{PERÍODO DA FAMÍLIA REAL NO BRASIL}

Para contar esse período histórico, recorremos a Livros de História, neles encontramos as informações de que a Família Real chegou ao Brasil a partir de 1808, até essa data não se conseguia implantar um sistema educacional em nosso país. 
O século XIX, com a chegada dos nobres portugueses, começou à formação das elites governantes e dos quadros militares, fato que, permitiu uma nova ruptura com a situação anterior do Brasil.As medidas tomadas por Dom João VI, tinha como objetivo: preparar terreno para sua estadia nas terras brasileiras.

Segundo alguns autores o Brasil finalmente estava sendo "descoberto" e a partir desse momento histórico, o Brasil passou a ter uma complexidade maior. Vejamos as principais medidas de Dom João VI que foram: Abertura das Academias Militares, nos decorridos anos colocados abaixo:

- 1808 - Academia Real da Marinha;

- 1810 - Academia Real Militar;

- A partir de 1808 - Escolas de Medicina nos Estados da Bahia e Rio de Janeiro;

- 1818 - Museu Real

- 1810 - Biblioteca Real

- 1810 - Jardim Botânico

- 1808 - Ano da iniciativa mais marcante de Dom João VI, a Imprensa Régia.

No ano de 1816, foram convidados artistas franceses como Lebreton, Debret, Taunay, Montigny para a famosa "Missão Artística Francesa", essa influenciou em muito a criação da Escola Nacional de Belas Artes. Mas infelizmente, a Educação continuou a ter uma importância secundaria. O fato que mostra essa afirmação é que nas colônias espanholas já existiam muitas Universidades, sendo que:

- Em 1538, já existia a Universidade de São Domingos;

- Em 1551, a Universidade do México e a de Lima.

Considerando a existência de Universidades no Brasil, só no ano de 1909 é que passa a existir a Universidade Federal do Amazonas - UFA, essa reconhecida como a mais antiga universidade brasileira, a outra foi a USP - Universidade de São Paulo, inaugurada no ano de 1.934. A partir desse tópico que vem a seguir, colocaremos as informações obtidas por mais um período histórico brasileiro com referências a educação brasileira. 
Figura 04: Pintura da Figura de Dom João VI

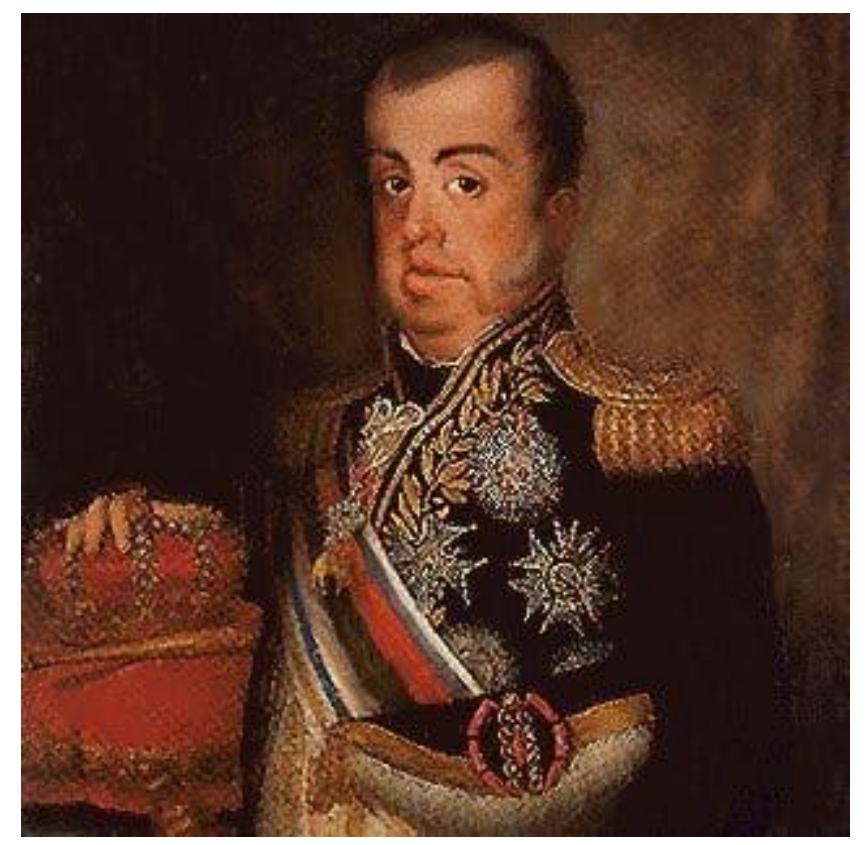

Fonte: Livro Literatura do Brasil (1959)

Nesse período chamado "joanino", o grande legado deixado por Dom João VI para o ensino elementar e médio foi sem sombra de dúvida a criação da ${ }^{2}$ Imprensa Régia através do Decreto de 13 de maio de 1808, a oficina foi constituída, originalmente, por um pesado material tipográfico, destinado à Secretaria de Estrangeiro da Guerra, recém-chegado da Inglaterra.

O primeiro Livro editado em seu período foi a Riqueza das Nações de Adam Smith e passou a ser editado um Jornal Diário - JD, chamado a Gazeta do Rio de Janeiro. Esse ato foi acompanhado da extinção da proibição de imprensa no Brasil, o que culminou imediatamente com a fundação de tipografias particulares no Rio de Janeiro, São Paulo e Salvador.

Outra medida que envolveu outras questões que não apenas a cultural obviamente, mas o que atraiu um bom número de intelectuais estrangeiros que foram responsáveis por um enorme salto no campo educacional e assim, modificações significativas para o sistema de educação do Brasil. 


\section{PERÍODO IMPERIAL}

O período imperial começa no dia sete de setembro do ano de 1822 quando $\mathrm{D}$. Pedro I declara a Independência do Brasil inspirada na Constituição Francesa, de cunho liberal, havia proposta para a Educação na Assembleia Constituinte inspirada nos ideais da Revolução Francesa, mas, a sua dissolução por D. Pedro I, adiou qualquer iniciativa no sentido de se estruturar uma política nacional de educação.

Em 1823, na tentativa de se suprir a falta de professores institui-se o Método Lancaster, ou método do ensino mútuo, onde um aluno treinado (decorriam) ensina um grupo de dez alunos (decúria) sob a rígida vigilância de um inspetor, vemos nessa medida, a desvalorização dos docentes, já que, o ensino seria ministrado por outro aluno.

No ano de 1824 foi outorgada a Primeira Constituição Brasileira, foi mantido nela (Constituição) o princípio da liberdade de Ensino Elementar. O Art.179 da Carta Magna afirmava e garantia a "instituição primaria e gratuita para todos os cidadãos brasileiros". No ano de 1826 um Decreto instituiu quatro graus de instrução no Brasil, seriam eles:

- Pedagogias nas escolas primarias

- Ginásios no ensino fundamental

- Liceus no ensino médio

- Academias no ensino superior

Em 15 de outubro do ano de 1827 um projeto de lei propõe a criação de Pedagogias em todas as cidades e vilas, além de prever o exame na seleção de professores, para nomeação e passarem a lecionar, ou seja, uma ampliação assegurada de novas pedagogias a serem aplicadas.

Propunha ainda a abertura de escolas para meninas, já que antes só os meninos poderiam ter uma escolarização. A primeira Lei sobre Ensino Elementar foi aprovada e vigorou até o ano de 1946. Essa Lei determinou a criação de novas maneiras de 
administrar o estudo para meninos e meninas no território brasileiro. Vejamos alguns artigos dessa Lei:

- Escolas de primeiras letras em todas as cidades, vilas e lugarejos (Art. $1^{\circ}$ );

- Escolas de meninas nas cidades e vilas mais populosas (Art. XI).

Mas, infelizmente, a Lei fracassou por várias causas econômicas, técnicas e políticas. Liberato Barroso fez um relatório que apontava a seguinte situação sobre a educação no Brasil no ano de 1867: "apenas $10 \%$ da população em idade escolar se matriculara nas escolas elementares".

Continuando a história da educação no Brasil, no ano de 1834, aprovado o Ato Adicional que emendou a Constituição, nele houve a reforma que deixava o ensino elementar, secundário e de formação de professores ficaria a cargo das "províncias", enquanto o poder central cuidaria do Ensino Superior.

Assim, graças a aprovação do Ato Adicional, no ano de 1835, surgiu a primeira Escola Normal do nosso país na cidade de Niterói, essa com finalidade de formar professores para o estudo elementar.

No ano de 1837, foi criado o Imperial Colégio de Pedro II, onde funcionava o seminário de São Joaquim, na cidade do Rio de Janeiro e os primeiros Liceus Provinciais, esse colégio era o único autorizado a realizar exames para a obtenção do grau de bacharel indispensável para o acesso a cursos superiores. Efetivamente o Colégio Pedro II não conseguiu se organizar até o fim do império para atingir o objetivo traçado.

Em 1879, houve uma reforma, a de Leôncio de Carvalho, ela tinha como proposta o fim da proibição da matrícula para escravos, mas ficou por pouco tempo, após 80 anos retornaram os jesuítas, no século XIX ainda havia no Brasil a tendência de criar escolas religiosas.

Apesar do imperador ter forte afeição pela tarefa educativa, em sua gestão, pouco foi feito para que se criasse, no Brasil, um sistema educacional, tornando-se um triste fracasso para o imperador em nosso território 
Dentre as instituições criadas pelo imperador estavam essas que colocaremos a seguir com seu referido ano e localidades:

- Colégio São Luiz, fundado em Itu em 1867 e transferido para São Paulo em 1919;

- Colégio Caraça em Minas Gerais em 1829;

- Colégio Mackenzie, em São Paulo no ano de 1870;

- Colégio Americano em Porto Alegre no ano de 1885;

- Colégio Internacional em Campinas no ano de 1873;

Além dos colégios religiosos acima citados, tem a iniciativa leiga surgindo uma das mais importantes instituições para nosso território, vejamos: Sociedade de Culto à Ciência, na cidade de Campinas, fundada por maçons.

Esse período histórico mostra que apesar da tentativa das mudanças na educação do Brasil, o quadro geral do ensino era de poucas instituições escolares não atendendo a maioria da população que necessita de um sistema de ensino que viesse dar qualidade em suas formações.

Continuando a história da Educação no Brasil, queremos retratar em nosso próximo assunto a primeira república, nele veremos como se deu a educação, se houve avanços ou retrocessos nesse período histórico brasileiro.

Para nossa pesquisa, é fundamental que saibamos todas as etapas da formação do sistema educacional do Brasil, assim, valorizaremos a educação da população em sua essência e nos tornaremos educadores preocupados em darmos qualidade de ensino para nossos educandos.

Constatamos que até o final do período imperial o sistema escolar não conseguiu se organizar de forma efetiva e se tornasse uma referência educacional em todo território brasileiro, infelizmente.

Veio o fim do império no Brasil, o estudo da história da educação nos mostrou que apesar de propostas interessantes para fortalecimento de estudos em nosso país, não 
houve nada de concreto na educação brasileira, fazendo com que as ações educacionais permanecessem escassas e divididas sem a ocorrência de um sistema de educação efetivo e com qualidade.

\section{PRIMEIRA REPÚBLICA UM PERÍODO IMPERIAL}

No ano de 1889 com a Proclamação da República, o Brasil adotou o federalismo e o poder, até então centralizado no imperador, foi dividido entre o presidente e os governos estaduais, quanto à educação, essa sofreu mudanças, mas sempre sob os princípios adotados pelo novo regime, suas características principais eram: centralização, formalização e autoritarismo.

Esse período foi marcado pelo desenvolvimento da indústria, pela reestruturação da força de trabalho, agora não mais escrava, pelas greves operarias e pela Semana de Arte Moderna. Segundo Palma Filho, durante a Primeira República entre os anos de 1889-1930, foram aprovadas cinco Reformas, são elas:

- Reforma Benjamim Constant

- Reforma Epitácio Pessoa

- Reforma Rivadavia

- Reforma Carlos Maximiliano

- Reforma João Luiz Alves

Falando de educação e política a partir de 1900, foi inaugurada a "Política dos Governadores ou dos Estados", que buscava empreender o entrosamento entre União e Estados. Esse modelo, interferiu diretamente na atuação do Congresso que havia se tornado submisso aos desígnios presidenciais, e sujeito a troca de favores, atendendo principalmente aos grupos oligárquicos das unidades federativas que tinham seus interesses assegurados.

Essa prática política perpetuaria as grandes famílias de oligarcas, a base desse sistema estava a mecânica eleitoral excludente e corrupta. Esse pensamento é fundamentado em Love (1975) que ressaltou: 
Os analfabetos não votavam; num país quase sem escolas, apenas $6 \%$ da população constituía o eleitorado. E, a maior parte desse eleitorado era manipulada. Primeiro pelo voto de curral, predominante no interior, onde o incontestado poder dos coronéis agrupava os submissos eleitores em grupos fechados, votando em quem o potentado escolhesse. Segundo pelo voto de cabresto, na cidade e no campo, voto comprado por meio de favores, ou mesmo através de dinheiro vivo. Finalmente, nas mesas eleitorais os coronéis e seus prepostos faziam votos fantasmas, ausentes, falsificavam as atas e fazia sumir o menor traço de oposição. Se algum coronel dissidente da política estadual conseguisse fazer representantes ao Congresso, a "degola" se encarregava do resto (LOVE, 1975, p. 63).

Triste história educacional brasileira, o pensamento de Love mostra a educação esquecida sendo ofuscada pela política imperialista, coronéis manipulavam votos fantasmas para ficar no poder, mas, o mundo passava por vários acontecimentos que influenciam nas histórias dos países, esses fatores ecoam na educação do Brasil, é propagada a ideia do ensino como direito público se fortaleceu e começaram a surgir modelos educacionais se perpetuaram.

Além das reformas acima citadas, no ensino secundário, foi implantado um currículo unificado para todo país, pois, em 1891, através de Benjamim Constant quando era Ministro da Instrução, Correios e Telégrafos, o Ensino Secundário era visto meramente como preparatório para o Ensino Superior.

Entre os anos de 1911-1915, vigorou a "Reforma Rivadavia", ela era iniciativa do Ministro Rivadavia Correa, o objetivo principal dessa Reforma é que seria afastada da União a responsabilidade pelo ensino. No referido período também surgiu o conceito de "Grupo Escolar", quando as classes deixaram de reunir alunos de várias idades e passaram a distribuí-los em "Ensino Seriado".

Para completar esse período histórico, as décadas de 1920 e 1930 surgiu o "Escolanovismo", de iniciativas de liberais democráticos, eles empreenderam 
reformas educacionais em diversos estados, se esperava que a educação avançasse com melhorias, vejamos:

- No Ceará, em 1923 - Lourenço Filho;

- Na Bahia, em 1925 - Anísio Teixeira; entre outras.

No ano de 1924 foi fundada a ABE - Associação Brasileira de Educação, essa na primeira fase sofrera influência da militância católica, mas, a partir de 1932, foi dominada pelos adeptos da Escola Nova. Segundo Anísio Teixeira (1925, p.32), a escola deveria mostrar praticidade e iniciação de trabalho e ressalta que a escola:

Não pode ser uma escola de tempo parcial, nem uma escola somente de letras, nem uma escola de iniciação intelectual, mas uma escola sobretudo prática, de iniciação ao trabalho, de formação de hábitos de pensar, hábitos de fazer, hábitos de trabalhar e hábitos de conviver e participar em uma sociedade democrática cujo soberano é o próprio cidadão (TEIXEIRA, 1971, p. 32)

O período republicano vivia uma instabilidade política, esse foi decorrente por três motivos

- Primeiro: dá não incorporação das classes sociais populares à política;

- Segundo: em razão do aumento das divergências e dissensões entre grupos dominantes em cada Estado ou entre as elites dos dois Estados mais importantes da Federação;

- Terceiro, porque as classes populares não tinham como expressar eleitoralmente; devido ao uso da violência, tanto dos "coronéis do sertão": nas pequenas localidades qual mantinha o domínio, como da violência oficial através da intervenção das forças armadas, convocadas para intervir nos Estados, sempre que a situação fugisse ao seu controle.

Os grupos escolares surgiram como estratégia da elite republicana paulista constituiu um modelo de escola a ser implantados por outros Estados do país. Vários grupos escolares continuaram sendo inaugurados, tanto no interior paulista como na capital, 
além deles as escolas isoladas, escolas preliminares, escolas provisórias, ambulantes $\mathrm{e}$ isoladas, etc.

Contudo, as escolas criadas não foram em números suficientes para atender a demanda, daí o projeto republicano para a educação que tinha como objetivo principal: "transformar no tempo em uma escolarização rápida e para todos, principalmente nos anos de 1920 a 1930, é quando a educação passa por uma fase de mudanças e transformação".

Após a esses acontecimentos, chegamos a um novo período histórico brasileiro, vejamos como a educação foi tratada nesse período que retrataremos e que foi chamado de Era Vargas.

Por tudo que discorremos, pudemos observar que não há defasagem entre educação e desenvolvimento, isso se pensarmos numa maneira de defasagem entre os produtos acabados oferecidos pela escola da época e a demanda social e econômica de educação, pois, mesmo no terreno da expansão quantitativa das oportunidades educacionais, o esforço feito na Primeira República não foi suficiente para compensar o crescimento da população em idade escolar.

\section{ERA VARGAS}

Chegamos no período histórico da Era Vargas, nela as propostas da Nova Escola e de Paulo Freire ganham força, mas, não chegam as salas de aulas. É a partir de 1930 que surgem as reformas educacionais mais modernas em defesa da Educação Pública gratuita e laica.

O Decreto 19.850 de 11 de abril de 1931 organizou o Conselho Nacional de Educação e a Constituição de 1934 deu-lhe a incumbência de criar o Plano Nacional de Educação. Em 1932 a forma pela Educação se sobressai com o Manifesto dos Pioneiros da Educação Nova, assim, na emergência do mundo urbano industrial, as discussões em torno das questões educacionais começam a ser o centro de interesse dos intelectuais. 
Daí tanto a Constituição de 1934, quanto o Manifesto de 1932 traçaram pela primeira vez as linhas mestras de uma política educacional brasileira. Com o comprovado aumento do analfabetismo no Brasil, atingindo um percentual de 80\%, em 14 de novembro de 1930, com o Decreto de nำ19. 402, foi criado o Ministério dos Negócios da Educação e Saúde Pública. O Ministro Francisco Campos reformulou o Ensino Secundário.

Com a atenção dos intelectuais para a educação, eles traçaram o objetivo de contribuir para a melhoria do processo de estabilização social, em pouco tempo, declararam a insuficiência da pedagogia tradicional diante das exigências do mundo moderno, capitalista, e concluíram que as instituições escolares deveriam ser atualizadas de acordo com a nova realidade social de nosso país que passa por várias transformações.

Mas, a Constituição de 1934 durou pouco, ela foi substituída pela Constituição de 1937, essa imposta por Getúlio Vargas, como mencionado anteriormente na década de 1920 havia universidades que mencionaremos a seguir, todas tiveram uma grande importância na educação no Brasil:

- No Amazonas, Universidade Federal do Amazonas (1909),

- No Rio de Janeiro (1920),

- Em Minas Gerais; Universidade Federal de Minas Gerais (1927).

Essas eram simples agregação de faculdades, assim, em 1934, surgiu a USP Universidade de São Paulo, ela sob a nova organização decretada pelo governo.

Para atender aos anseios da nova realidade, o ministro Gustavo Capanema incentivou novas leis de reformas de ensino que ficaram conhecidas como: "Reforma Capanema", no ano de 1942.

Nesse mesmo ano, foram promulgadas as Leis Orgânicas do Ensino Industrial e a Lei Orgânica do Ensino Secundário, além de ter sido fundado o SENAI - Serviço Nacional de Aprendizagem Industrial. 
Essas Leis determinavam que o Ginásio, passaria a ter quatro anos e o Colegial, três. Foi criado também o curso supletivo de dois anos para a população adulta e a Rede Pública foi organizada em escolas com uma, duas a quatro e cinco ou mais classes, além da escola supletiva, assim:

- Em 1943, foi aprovada a Lei Orgânica do Ensino Comercial;

- Em 1946 a Lei Orgânica do Ensino Primário e Normal e a Lei Orgânica do Ensino Agrícola.

Também houve o acordo financeiro com o Banco Mundial para a Escola Técnica de Curitiba. Com a lei orgânica, o Ensino Secundário foi dividido em três modalidades descritas como:

- Clássico,

- Científico

- Normal

Esse último embora profissionalizante, era considerado dentro do ensino secundário, voltado para o prosseguimento de estudos em nível superior e técnico, com três modalidades de cursos, técnico industrial; técnico agrícola e técnico comercial. Mas, as doutrinas totalitaristas se expandiam na Europa e, Vargas se inspira e instituiu o ${ }^{5}$ Estado Novo (1937-1945).

Com o fim do governo Getulista, surgiu em 1946 uma Constituição, a qual trouxe dispositivos dirigidos à educação, como a gratuidade para o Ensino Primário e a manutenção da mesma na sequência dos estudos, para aqueles que comprovassem falta de recursos. Em 1948, também surgiu a discussão para uma Lei de Diretrizes Básicas, a partir da proposta do deputado Clemente Mariani.

No decorrer de treze anos foram promovidos debates pelos escolanovistas e católicos tradicionalistas, entre os de batentes, o padre Leonel Franca e Alceu Amoroso Lima, além do "Manifesto dos educadores mais uma vez convocados", (1959), foi assinado por Fernando de Azevedo e mais 189 pessoas, sendo aprovada a Lei de no 4.024/61, 
essa Lei instigou o desencadeamento de vários debates acerca do tema "Educação Brasileira".

Ao concluirmos a Era Getulista com o celebre comentário de Paulo Freire (1996), em seguida descreveremos o período histórico chamado de Regime Militar e quais as mudanças ocorridas nesse período:

Na visão bancária da Educação, o 'saber' é uma doação dos que se julgam sábios aos que julgam nada saber. (...) O educador, que aliena a ignorância, se mantém em posições fixas, invariáveis. Será sempre o que sabe, enquanto os educandos serão sempre os que não sabem. A rigidez dessas posições nega a Educação e o conhecimento como processos de busca (PAULO FREIRE, 1996, p. 57)

O modelo político educacional da Era Vargas, estava constantemente colocado a prova, pois várias ideologias emergiam e imergiam muito rápido, foi o que aconteceu com o catolicismo oligárquico que ora estava no poder, orar os ideários do liberalismo, ou mesmo o comunismo e o integralismo.

Salientamos que as ideologias pedagógicas mundiais chegavam ao nosso país e refletiam diretamente na educação do Brasil, justamente ligada pela classe dominante em que estava no poder, criando assim, uma sociedade conforme os moldes necessários para o governo de ${ }^{6}$ Getúlio Vargas que soube trabalhar muito bem essa questão de política educacional seja perder o prestígio de governante e muito menos de "Pai dos Pobres".

\section{REGIME MILITAR}

No ano de 1964, tem início o regime militar e as propostas de uma Educação mais democrática foram abandonadas. Nesse período, a Educação ficou marcada pelo autoritarismo, as organizações estudantis foram banidas, a UNE - União Nacional dos Estudantes foi considerada subversiva pelo sistema no ano de 1967. 
Paulo Freire (1921-1997) foi exilado no Chile e a Escola Nova deixou de ser considerada para as políticas públicas. No ano de 1969, se tornou obrigatório o ensino de Educação Moral e Cívica em todos os níveis de ensino, sendo que no ensino secundário, a comunicação mudava para organização Social e Política Brasileira (OSPB).

O Decreto 68 908/71 criou o "Vestibular Classificatório", garantindo a vaga nas universidades apenas até o preenchimento das vagas disponíveis. Tentando dar, à educação, contornos tecnicistas, o Brasil assinaria, em 1964 os acordos MECUSAID, (Ministério da Educação e Cultura e United States Agency for International Development).

No ano de 1961, a Lei de Diretrizes e Bases não foi revogada, mas, passou por uma série de modificações com a Lei de n 5.540/68, baseada nas diretrizes decididas a partir do Relatório ATCON (Rudolph Atcon) e Relatório Meira Mattos (Coronel da Escola Superior de Guerra).

No ano de 1967, Na Educação de adultos, as ideias de Freire deram lugar a um modelo assistencialista por meio do Movimento Brasileiro de Alfabetização (Mobral). A leitura passou a ser tratada como uma habilidade instrumental, sem contextualização.

Claro que o governo tentava diminuir os níveis de analfabetismo, muito grande entre os adultos brasileiros. Cada governo vinha com proposta para educação, no governo Médici, foi realizada a reforma dos ensinos fundamental e médio com a Lei 5.692/71.

A Lei do governo Médici, integrou o primário, ginásio, secundário e técnico. Nessa Lei, a disciplina de filosofia desapareceu no segundo grau e outras foram aglutinadas, a História e Geografia formaram, no $1^{\circ}$ grau, "Estudos Sociais". Outra que desapareceu foi a Escola Normal.

No ano de 1982, a Lei 7 044/82 retirou a obrigatoriedade do Ensino Profissionalizante nas Escolas de Ensino Médio, já havia muitos técnicos formados suprindo a mão de 
obra, antes necessária. Após o sufocante regime militar, chegamos ao ano da retomada da democratização brasileira.

A Educação veio com destaque na Constituição de 1988 que em seus dispositivos transitórios onde ADCT -Ato das Disposições Constitucionais Transitórias - 60 modificado pela Emenda Constitucional 14/1996, ela dava o prazo de dez anos para a universalização do Ensino e a erradicação do analfabetismo no Brasil.

A legislação tornou urgente a tomada de providências como a abertura de mais escolas e a formação de docentes, o que acarretou a necessidade de investimentos. Para isso, a lei indicava a aplicação na área de no mínimo $18 \%$ da receita dos impostos pela União e $25 \%$ pelos estados e municípios.

Outro fato relevante para a educação no ano de 1996, foi o surgimento da nova LDB - Lei de Diretrizes e Bases para a Educação - ela instituiu a Política Educacional Brasileira. A Lei 9131/1995 criou o Conselho Nacional de Educação, substituindo o antigo Conselho Federal de Educação que havia surgido com a LDB de 1961 e tinha sido extinto em 1994.

No ano de 1990 havia sido organizado o SAEB - Sistema de Avaliação do Ensino Básico e com a Lei de n 9.424/96 foi organizado o FUNDEF - Fundo de Manutenção do Desenvolvimento do Ensino Fundamental, esse depois de dez anos foi substituído foi substituído pelo FUNDEB, ele obrigou os estados e municípios a aplicarem anualmente um percentual mínimo $60 \%$ para o pagamento do pessoal do magistério.

Dois anos depois, ou seja, 1990, durante a Conferência Mundial sobre Educação para Todos em Jomtien, na Tailândia, foi aprovada uma declaração internacional que levava o nome do evento e propunha ações para os dez anos seguintes com vistas à universalização do ensino nos países signatários, o Brasil estava presente, como dito anteriormente aprovou a Emenda Constitucional 14/1996.

No Brasil, Fernando Collor de Mello assumiu a presidência e criou o Programa Nacional de Alfabetização e Cidadania (PNAC) em substituição à Fundação Educar - 
versão democrática para o Movimento Brasileiro de Alfabetização (Mobral) -, instituída cinco anos antes por José Sarney. Mas a iniciativa de Collor durou apenas um ano.

Analisar a história do Brasil, daria uma dissertação de mestrado, com certeza, colocamos no tópico acima que concluímos, apenas dados básicos, no que se segue promoverá, a ampliação dos conhecimentos necessários para que se entenda as fases que envolveram a educação brasileira, relataremos a partir daqui os paradigmas educacionais e o sistema escolar.

Ressaltamos que a educação do regime militar, no âmbito nacional, tem como resultado de inúmeros atos direcionados a ela. Esses atos usados como ferramentas ideológicos estatal, teve como herança diversas deficiências relacionadas aos erros do passado que prejudicaram inúmeros cidadãos que sofreram com a degradação do ensino que, nos dias de hoje não se recuperam das ações dos sistemas anteriores.

Figura 05 Conexões Civis do Regime Militar

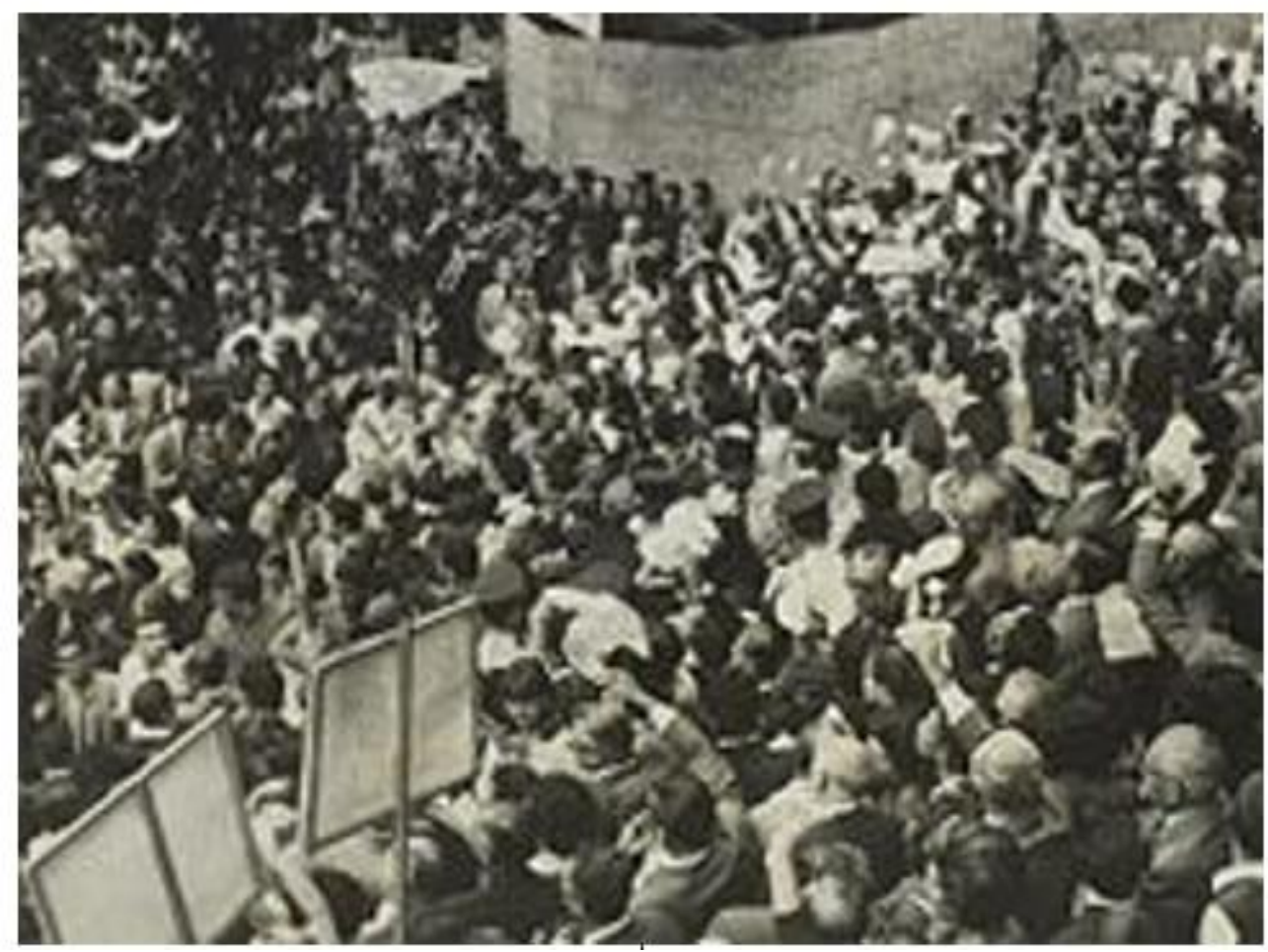

Fonte: Arquivo Nacional/Correio da Manha 
Manifestantes na Marcha da Família com em 19 de março de 1964 na Praça da Sé, em São Paulo.

Ao descrevermos sobre a educação no ${ }^{7}$ Regime Militar, vimos que foi estabelecido leis instituídas na educação como ferramentas para manipulação da sociedade brasileira, sendo utilizadas tais Leis totalmente autoritárias e radicais, que se instituíam através do poder monopolizador nos estabelecimentos educacionais e a sociedade, voltado a uma ideologia tecnicista com propósitos capitalistas.

\section{PARADIGMA EDUCACIONAL E O SISTEMA ESCOLAR}

Ao descrevermos sobre a história do Brasil, percebemos que a escola brasileira teve sempre paradigmas para sua orientação, mas, esses paradigmas construídos de acordo com os interesses políticos, econômicos e sociais que direcionavam os objetivos e as finalidades do processo educativo, da ação docente, das relações estabelecidas entre a aprendizagem e a realidade fora da escola.

Constatamos também que a história da educação foi marcada por as tais determinações impostas, sendo centro ideológico do sistema operante do governo que defendia interesses próprios e pouco se pensava nas necessidades da população. Veio o governo de Fernando Henrique Cardoso em 1995, com ele várias regulamentações surgiram, nomeado Paulo Renato Souza como ministro da Educação.

No segundo ano de mandato FHC, promulga a LDB- Lei de Diretrizes e Bases da Educação Nacional, daqui para frente toda dissertação trará informações sobre essa Lei de fundamental importância para Educação e a Formação Docente, tema principal que estamos investigando relacionando-o ao Município de Aquiraz.

Atualmente os Documentos Oficiais de referência a Educação é a LDB e as DC (Diretrizes Curriculares). Muitos estudiosos do tema Educação, apontam a necessidade de que escolas assumam sua autonomia e abordagens críticas para agir como orientadora das intervenções e transformação da sociedade. 
Para defender sua autonomia as escolas precisam ter em suas propostas educativas ações políticas, culturais e sociais e proporcionem uma educação integral e qualificada aos educandos que frequentam essas instituições educacionais. Pensamento fundamentado no relatório do senador Darcy Ribeiro (1922-1997) estipulou a formação do docente em nível superior colocando a educação infantil na posição de etapa inicial da educação básica, na LDB ressalta que:

A nova lei reforçou aspectos importantes da Constituição como a municipalização do Ensino Fundamental, estipulou a formação do docente em nível superior e colocou a Educação Infantil na posição de etapa inicial da Educação Básica (RIBEIRO, 1997, LDB)

Estava também ressaltado na Nova LDB que $1^{\circ}$ e $2^{\circ}$ graus se tornariam Ensino Fundamental e Médio e a recomendação para os estudantes com necessidades educacionais especiais passariam a ser atendidos preferencialmente na rede regular de ensino, esse Art. encontra-se na LDB e ECA.

$\mathrm{Na}$ atualidade, os educadores precisam se adequar aos Novos tempos para propor Novas Metodologias que venham atender a um Novo Paradigma Emergente que poderia ser chamado de Paradigma da Complexidade esse fundamentado na preocupação da Organização Internacional UNESCO, que propõe uma educação para o século XXI sustentada em quatro pilares, são eles:

Quadro 01: Pilares da Educação

Aprender a conhecer

Aprender a pensar

Aprender a conviver

Aprender a ser

Fonte: Estudos da UNESCO

Com o Novo Paradigma da educação, FHC venceu eleições para um segundo mandato e o ministro da educação Luiz Francisco Fernandes de Souza, institui alguns 
programas e medidas para avaliação da educação, que por sua vez, começa a ser marcada pelas dúvidas e incertezas com relação ao projeto educativo diferentes dos critérios rígidos do paradigma conservador, no novo as vezes, os papeis se confundiam. No quadro abaixo colocaremos programas e medidas toadas pelo ministro Souza

Quadro 02: Programas e Medidas do Governo FHC

\begin{tabular}{|c|c|c|c|}
\hline Sigla & Significado & Sigla & Significado \\
\hline Pisa & $\begin{array}{l}\text { Programa Internacional de } \\
\text { Avaliação dealunos }\end{array}$ & RCNEI & $\begin{array}{l}\text { Referencial Curricular Nacional } \\
\text { paraEducação Infantil }\end{array}$ \\
\hline Enem & $\begin{array}{l}\text { Exame Nacional do Ensino } \\
\text { Médio }\end{array}$ & PCN & Parâmetro Curriculares Nacionais \\
\hline DCN & $\begin{array}{l}\text { Diretrizes } \quad \text { Curriculares } \\
\text { Nacional }\end{array}$ & CNE & Conselho Nacional de Educação \\
\hline
\end{tabular}

Fonte: ARAÚJJ, Marciano V. de baseado nas informações do MEC (1998)

Chegamos ao ano de 2001, mais um plano foi aprovado o PNE - Plano Nacional de Educação, esse previsto na Constituição e válido por dez anos e estipulava metas para aumentar o nível de escolaridade dos brasileiros e garantir o acesso à Educação. No governo de Luiz Inácio Lula da Silva, ele levou para seu Ministro da Educação Cristovam Buarque, lançou o Brasil Alfabetizado no lugar da Alfabetização solidária criada por FHC no ano de 1997. Com um esforço contínuo para combater o analfabetismo no Brasil, houve uma diminuição significativa.

Resumidamente os paradigmas da educação ocorreu como uma linha do tempo, com a aprovação de PROGRAMAS e MEDIDAS nos governos em sequência, cada um defendendo seus interesses para avanços na educação, uns tiveram sucesso, outros, levaram a educação a retrocessos. No quadro abaixo colocaremos uma cronologia das principais medidas e ano: 
Quadro 03: Cronograma de Medidas e Programas da Educação

\begin{tabular}{|c|c|c|c|}
\hline Ano & Sigla & Significado & Objetivos \\
\hline 1988 & CF & Constituição Federal & Promulgada com atenção à educação \\
\hline 1990 & DM & Declaração Mundial & $\begin{array}{l}\text { Aprovada educação para todos na } \\
\text { Tailândia }\end{array}$ \\
\hline 1996 & LDB & $\begin{array}{l}\text { Lei de Diretrizes e Bases } \\
\text { da Educação }\end{array}$ & $\begin{array}{l}\text { Determina que docentes tenham } \\
\text { formação em nível superior }\end{array}$ \\
\hline 2001 & PNE & $\begin{array}{l}\text { Plano Nacional } \\
\text { Educação }\end{array}$ & $\begin{array}{l}\text { Traça metas para a universalização } \\
\text { do ensino }\end{array}$ \\
\hline 2010 & PN & Plano Nacional & $\begin{array}{l}\text { Aprovado o piso salarial nacional } \\
\text { para os docentes }\end{array}$ \\
\hline
\end{tabular}

Fonte: ARAÚJO, Marciano V. de, baseado nas informações do MEC (1997)

Segundo o MEC, a Organização do Sistema Educacional Brasileiro ocorre por meio dos sistemas de ensino da União, dos Estados, do Distrito Federal e dos Municípios, como informamos anteriormente a Constituição Federal de 1988 e a Lei de Diretrizes e Bases da Educação Nacional, são as leis que regem o sistema educacional brasileiro em vigor. Sua estrutura consiste em:

Quadro 04: Estrutura da Organização do Sistema da Educação Brasileira

\author{
Educação Básica \\ Educação Infantil \\ Ensino Fundamental \\ Ensino Médio \\ Educação Superior
}

Fonte; ARAÚJO, Marciano V. de, baseado nas informações do MEC (1988)

Para o sistema educacional brasileiro a Lei primordial da atualidade é a LDB 9394/96, com ela veio o grande objetivo, de se normatizar o sistema educacional e garantir acesso igualitário para todos com relação a educação. A LDB, de forma geral, oferece 
um conjunto de definições políticas que orientam o sistema educacional e introduz mudanças importantes na educação básica brasileira

Na LDB foi traçada a meta de democratização e universalização do conhecimento básico, oferecendo educação e cuidado com a escolarização, assumindo um caráter intencional e sistemático que oferece atenção especial ao desenvolvimento intelectual, físico, emocional, moral e social.

Quanto a função do sistema de educação os municípios têm a função educacional de atuar no ensino fundamental e na educação infantil. Os Estados e o Distrito Federal são responsáveis sobre o ensino fundamental e médio. O Governo Federal deve prestar assistência técnica e financeira aos Estados, Distrito Federal e Municípios, e organizar o sistema de educação superior no país.

Quadro 05: Atual Estrutura do Sistema Educacional Regular no Brasil

\begin{tabular}{|c|c|}
\hline EDUCAÇÃO BÁSICA & FUNCIONALIDADE \\
\hline \multirow[t]{2}{*}{ Educação infantil } & Realizada em creches para crianças de 0 a 3 anos \\
\hline & Pré-escola para crianças de 4 a 6 anos \\
\hline Ensino fundamental & $\begin{array}{l}\text { Duração mínima de } 9 \text { anos, conforme lei } 11.274 \text {, é } \\
\text { obrigatório e gratuito na escola pública }\end{array}$ \\
\hline Ensino médio & Duração de três anos, prepara o educando para o trabalho \\
\hline \multirow[t]{2}{*}{ Educação superior } & $\begin{array}{l}\text { Abrange os cursos de graduação nas diferentes áreas } \\
\text { profissionais, são disponíveis aos candidatos que tenham } \\
\text { concluído o Ensino Médio ou equivalente e tenham sido } \\
\text { classificados dentro do número de vagas em processo } \\
\text { seletivo específico. }\end{array}$ \\
\hline & $\begin{array}{l}\text { A Pós-graduação também faz parte do nível superior de } \\
\text { educação e compreende programas de especialização, } \\
\text { mestrado, doutorado e pós-doutorado }\end{array}$ \\
\hline
\end{tabular}

Fonte: ARAÚJO, Marciano V. de. Baseado em dados do MEC 
Os sistemas educacionais e os movimentos educativos, segundo Paiva (1985), embora influam sobre a sociedade a que servem, refletem basicamente as condições sociais, econômicas e políticas dessa sociedade. Assim, as características dos diversos períodos históricos dos estados/país vão refletir as transformações econômicas e sociais, as lutas dos diversos setores da sociedade pela hegemonia política, pois para Paiva (1985):

Toda educação provém de uma situação social determinada e as metas educacionais, a política da educação e a orientação do ensino mostram de forma clara o seu caráter histórico. Por outro lado, a forma como o movimento da sociedade se reflete na educação pode ser observada mais claramente sempre que se inicia um período de transformações e o sistema educacional existente (ou em formação) já não atende as novas necessidades criadas, necessitando ou de ampliação urgente ou de movimentos paralelos que preencham as lacunas deixadas pela organização do ensino vigente (PAIVA, 1985, p. 19)

Dentro do sistema educacional, segundo o MEC, além do ensino regular, a educação formal do Brasil possui as modalidades especificas de:

Quadro 06: Outras Modalidades de Ensino do Sistema Educacional

\begin{tabular}{|l|l|}
$\begin{array}{l}\text { Educação } \\
\text { Especial }\end{array}$ & Para os alunos com necessidades educacionais especiais \\
\hline $\begin{array}{l}\text { Educação de } \\
\text { Jovens e Adultos }\end{array}$ & $\begin{array}{l}\text { Para aqueles que não tiveram acesso ou continuidade de } \\
\text { estudos no ensino fundamental e médio na idade própria } \\
\text { para os mesmos. }\end{array}$ \\
\hline
\end{tabular}

Fonte: ARAÚJO, Marciano V. de. Baseado nas Informações dos dados do MEC.

O PNE, traça metas para a frequência da população estudantil brasileira, esse órgão colocou a estigmática dessa frequência em 2012 , sua meta é que até 2020 , todas as modalidades de ensino, tenha $50 \%$ de alunos, abaixo tem uma tabela fornecida pelo órgão com os dados de 2002 a 2012. Vejamos. 
Tabela 01: População dos Estabelecimentos de Ensino em suas Modalidades

População que frequenta estabelecimentos de ensino em 2002 em 2012

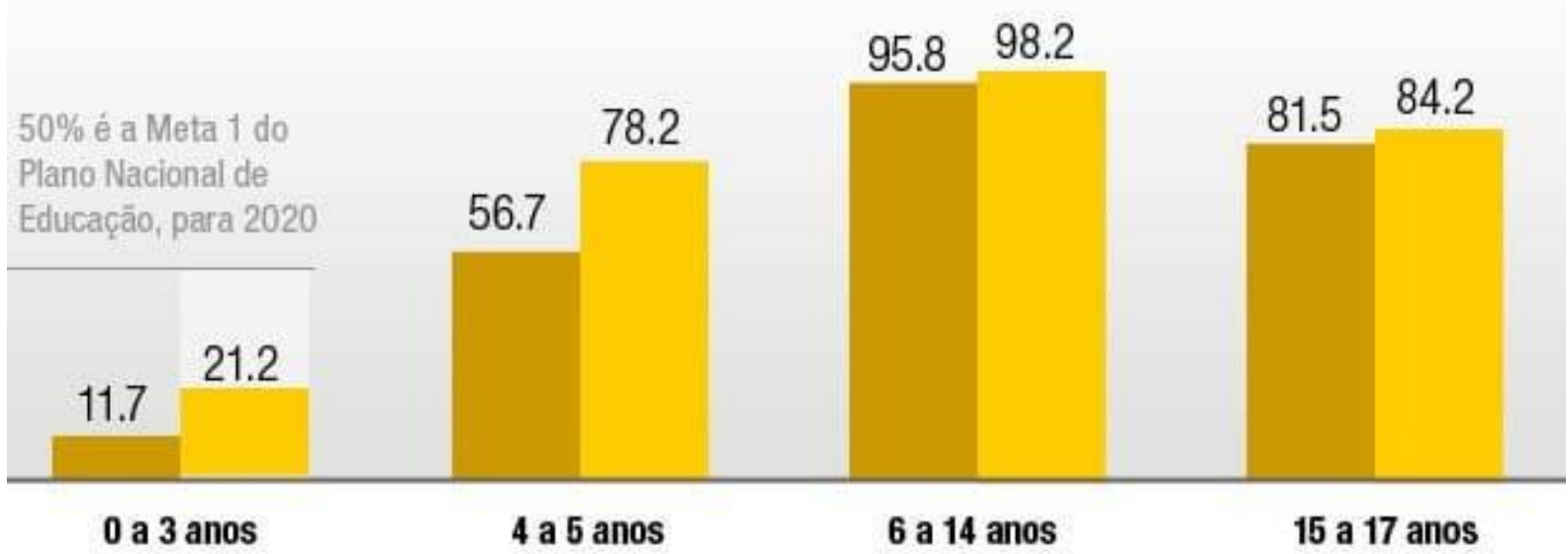

Fonte: ARAÚJO, Marciano V. Dados retirados do site do PNE (2012)

Para compreendermos a evolução e dimensão do Sistema Educacional Brasileiro, enquanto parte do Processo de Desenvolvimento Social, devemos levar em conta algumas considerações algumas premissas de grandes estudiosos da área:

Quadro 07: Evolução e Dimensão do Sistema Educacional Brasileiro

Saviani (1987): A compreensão do Sistema Educacional brasileiro exige que não se perca de vista a totalidade social da qual o sistema educativo faz parte. Ribeiro (1987): O sistema escolar é um dos elementos da superestrutura que forma, em unidade com o seu contrário a infraestrutura ${ }^{4}$ - estrutura social. Freitas (1986): a relação entre a infraestrutura e a superestrutura é uma relação determinante que não se dá de forma linear, direta ou absoluta, haja vista que a superestrutura tem refletido em si a contradição fundamental da infraestrutura - conservação $x$ transformação

Fonte: ARAÚJO, Marciano V. de. Baseado nas informações doMEC 
Ao falarmos sobre Educação Básica Brasileira, colocamos dados sucintos sobre sistema educacional, paradigmas e fundamentamos esses dados na LDB, Lei fundamental da educação, nossa pesquisa tem mostrado a educação direito de todos garantidos na Constituição Brasileira e demais Documentos.

Figura 06: Estrutura da Educação Brasileira

ORGANIZAÇĀO E ESTRUTURA DA EDUCAÇÃO BRASILEIRA
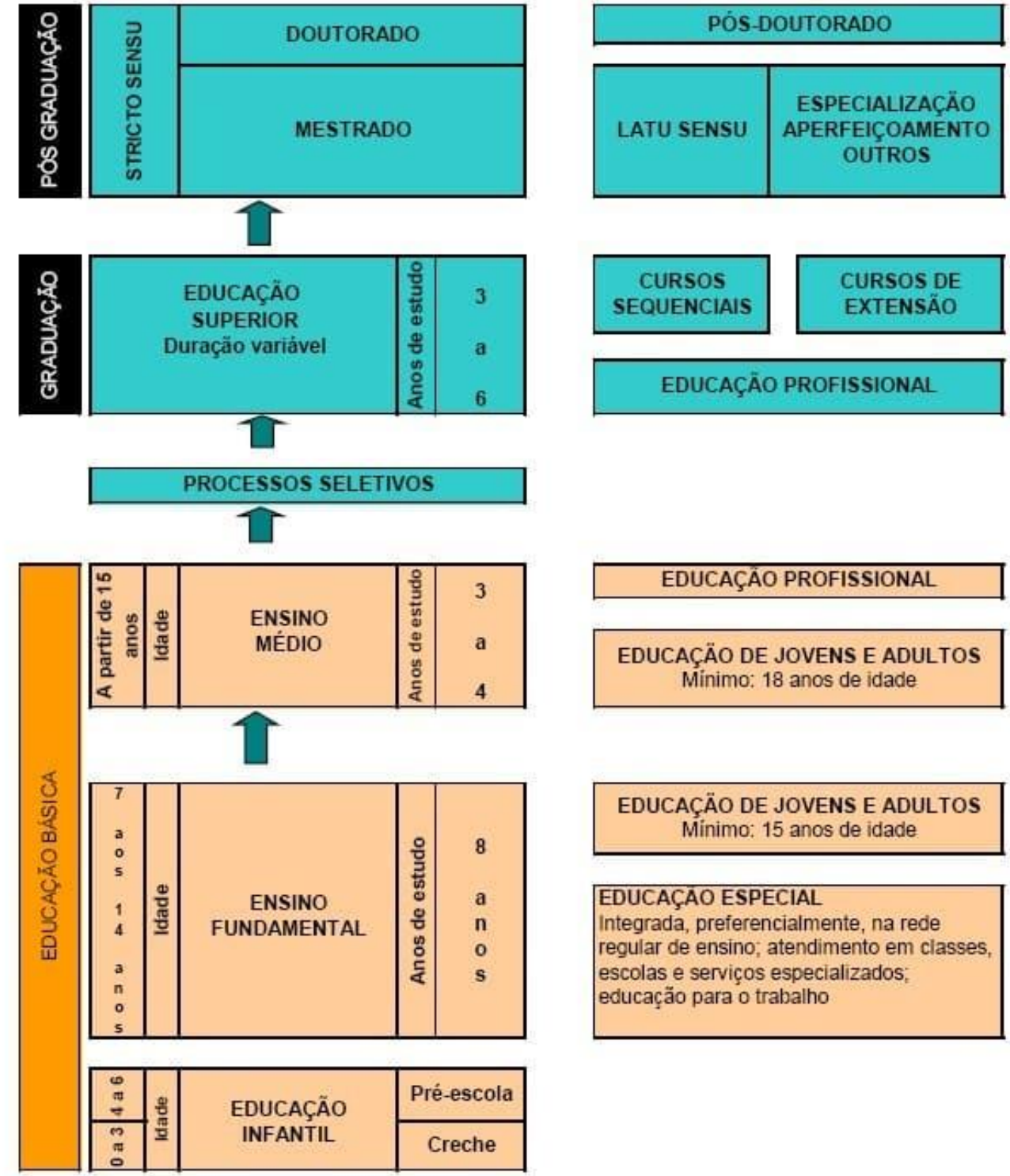

EDUCAÇĀO ESPECIAL

Integrada, preferencialmente, na rede regular de ensino; atendimento em classes, escolas e serviços especializados: educaçäo para o trabalho

Fonte: ARAÚJO Marciano V. de. Baseado nos dados da estrutura Elaborada pelo MEC 
O quadro mostrou paradigma educacional e o sistema escolar com a organização da estrutura da educação brasileira dissertando agora sobre a educação brasileira com as tendências educacionais e as ${ }^{9}$ abordagens pedagógicas.

\section{TENDÊNCIAS EDUCACIONAIS E AS ABORDAGENS PEDAGÓGICAS}

Grandes pesquisadores sobre educação em nosso país constataram que as tendências pedagógicas brasileiras foram bastante influenciadas pelo momento cultural e político da sociedade, pois, foram levadas à luz graças aos movimentos sociais e filosóficos. Essas formaram a prática pedagógica do Brasil em cada período histórico brasileiro.

Iniciaremos descrevendo as tendências na visão dos professores Saviani (1997) e Libâneo (1990), esses autores propõem uma reflexão aprofundada sobre as tendências pedagógicas.

Eles ressaltam também que as principais tendências pedagógicas usadas na educação brasileira se dividem em duas grandes linhas de pensamento pedagógico que são: Tendências Liberais e Tendências Progressistas.

Para os profissionais da educação é fundamental que eles se apropriem dessas tendências para que elas sirvam de apoio na sua prática pedagógica. Os professores mencionados que não se deve usar uma delas de maneira isolada em toda sua docência.

Analisando cada uma, o docente escolherá a que melhor convém ao seu desempenho acadêmico, com maior eficiência e qualidade de sua atuação para com os discentes que ministrará sua prática pedagógica.

A história da educação mostra que, de acordo com cada nova situação que surge, o educador usa a tendência mais adequada, notadamente se ver que hoje, na prática docente, há uma mistura de tendências. 
No quadro abaixo, serão colocadas as explicações das características de cada forma de ensino para que assim, seja compreendida cada tendência educacional em seu período histórico. Os pesquisadores, reforçam que uma tendência não substitui totalmente a anterior, mas, ambas estão dentro da prática ${ }^{10}$ pedagogica Falando das tendências pedagógicas, para Saviani (1986), defensor da função social da escola ressalta que:

A escola como idealizadora no século XIX que tinha como perspectiva assegurar o direito a educação para todos com qualidade, gratuidade $e$ a expectativa da classe dominante era que os membros das classes subalternas, uma vez instruídos, se ajustariam aos projetos dominantes, com o entendimento de que a instrução transformaria os "súditos em cidadãos"(Saviani, 1986, p.45)

Segue-se um quadro explicativo das tendências educacionais e a importância de cada uma delas na prática pedagógica do educador dentro do sistema de educação do Processo de Ensino-aprendizagem brasileira que se insere no contexto de estudos realizados na perspectiva profissional do professor sendo de extrema importância para o futuro da sociedade estudantil.

Quadro 08: Tendências Educacionais Brasileiras

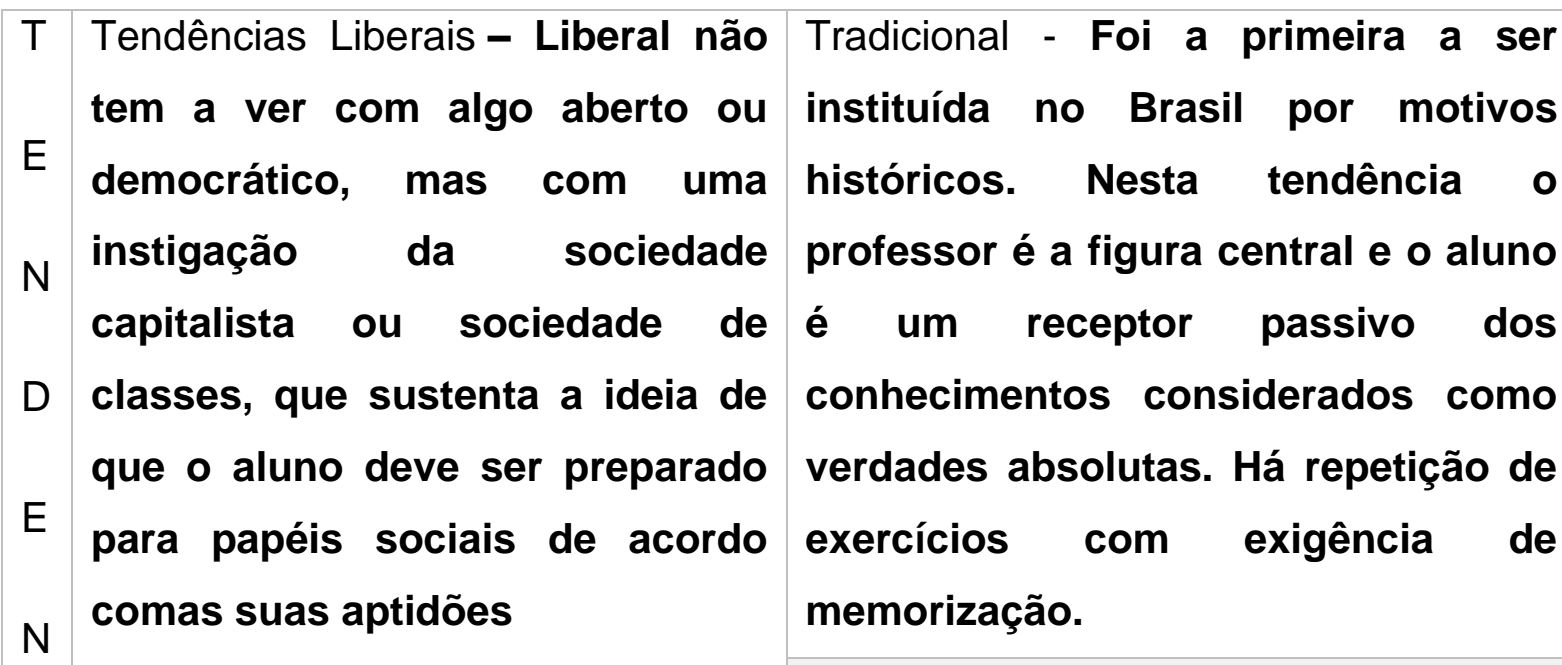

Renovadora Progressiva - Por razões de recomposição da hegemonia da 


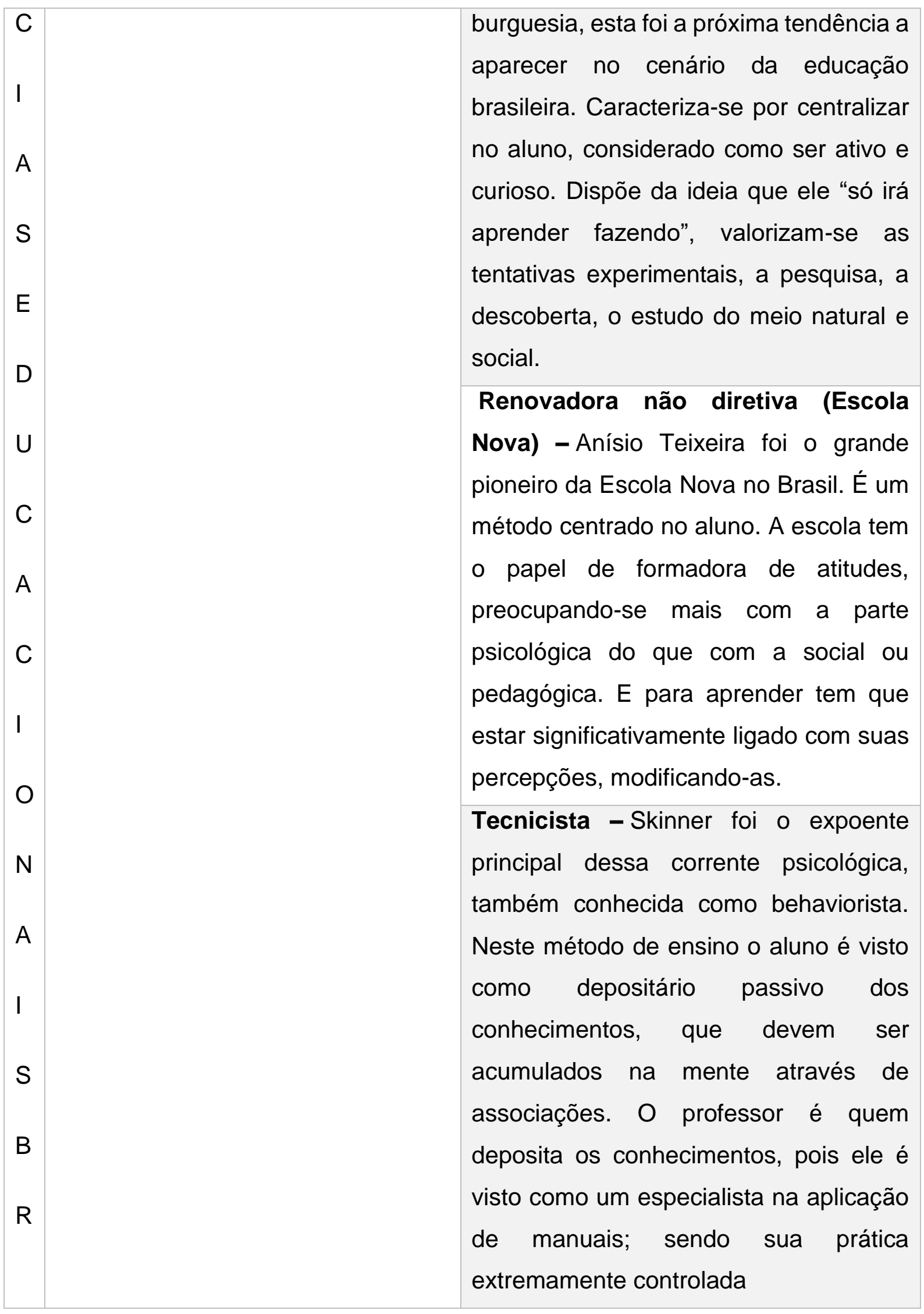




\section{A Tendências Progressistas \\ S Partem de uma análise crítica das realidades sociais, sustentam implicitamente as finalidades \\ L Sociopolíticas da educação e é uma tendência que não condiz com as \\ E ideias implantadas pelo capitalismo.}

$\mathrm{R}$

A

S

Fonte: ARAÚJO, Marciano V. de. Baseado nas Informações elaboradas pelo MEC
Libertária - Procura a transformação da personalidade num sentido libertário e auto gestionário. Parte do pressuposto de que somente o vivido pelo educando é incorporado e utilizado em situações novas, por isso o saber sistematizado só terá relevância se for possível seu uso prático. Enfoca a livre expressão, o contexto cultural, a educação estética.

"Crítico-social dos conteúdos" ou "Histórico - Crítica" - Tendência que apareceu no Brasil nos fins dos anos 70 , acentua a prioridade de focar os conteúdos no seu confronto com as realidades sociais, é necessário enfatizar o conhecimento histórico.

Crítico - social dos conteúdos" ou "Histórico - Crítica" - Tendência que apareceu no Brasil nos fins dos anos 70, acentua a prioridade de focar os conteúdos no seu confronto com as realidades sociais, é necessário enfatizar o conhecimento histórico. Prepara o aluno para o mundo adulto, com participação organizada e ativa na democratização da sociedade; por meio da aquisição de conteúdos e da socialização. 
Sabemos que as tendências pedagógicas seguem cada período histórico da realidade brasileira e que a formação do professor traz orientações na perspectiva de aquisição de saberes disciplinares e transdisciplinares para desenvolver integralmente os educandos contribuindo assim, no reforço do potencial das competências e habilidades que trazem ao entrar na escola.

Para entendimento da estrutura das ${ }^{11}$ tendências educacionais brasileira, estrutura essa devidamente definida no quadro anterior, no que se segue, especifica como teóricos do assunto o estruturou.

Figura 07: Estrutura das Tendências Educacionais

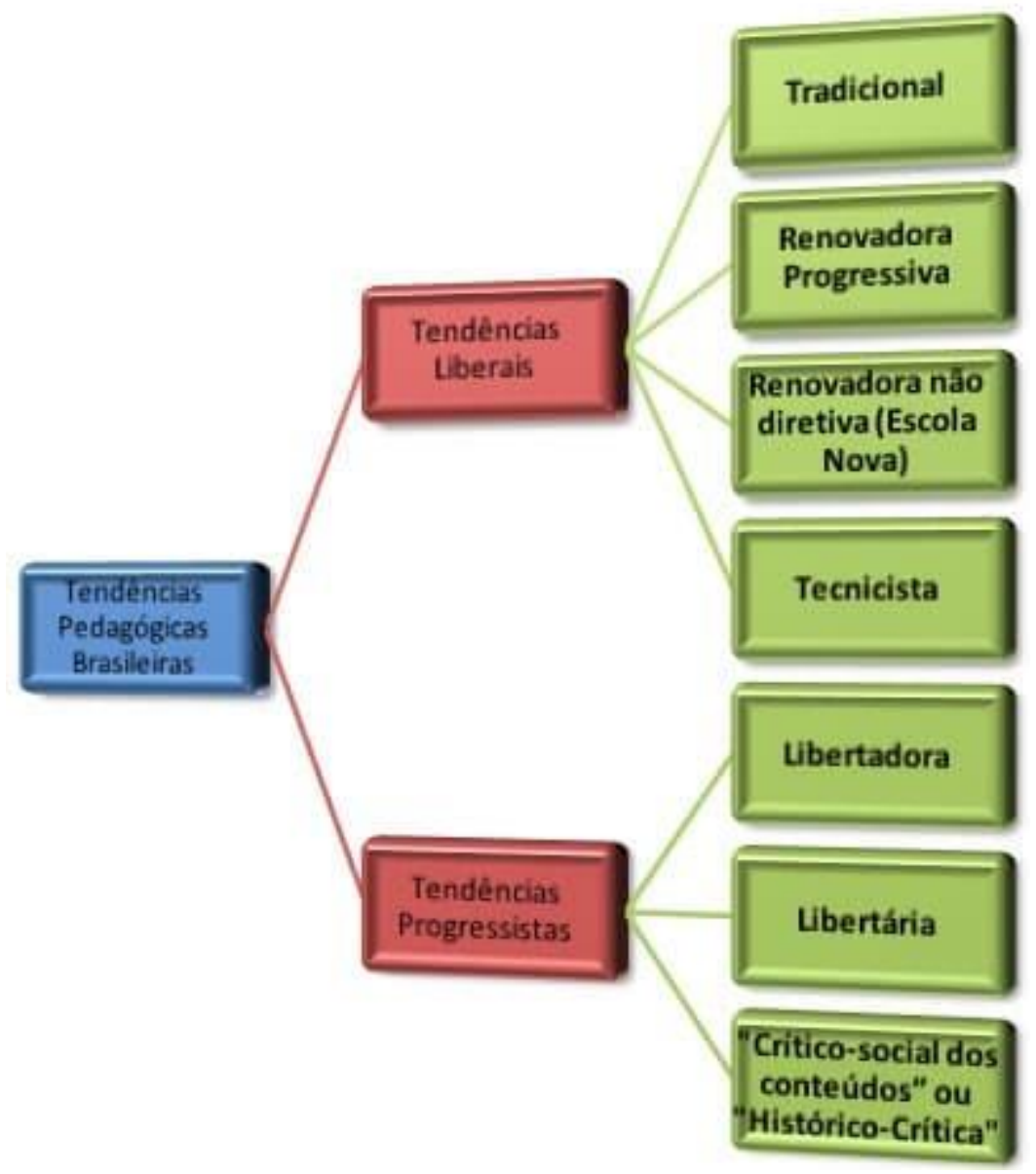

Fonte: ARAÚJO, Marciano V. de. Baseado nas Informações dos estudos de Saviani e Libâneo 
Após descrevermos sobre as tendências educacionais brasileiras, ressaltaremos as abordagens pedagógicas de ensino que foram disseminadas ao longo da história na educação brasileira.

Devemos salientar que cada abordagem sofreu influências de diferentes teóricos, esses realizavam seus posicionamentos didáticos de acordo com seus estudos.

Para entendimento colocaremos no quadro a seguir as características e formas de utilização dos principais elementos didáticos ligados a essas abordagens como: a escola, o processo de ensino-aprendizagem, a relação professor/aluno, a metodologia e a avaliação.

Quadro 09: Informações da Abordagem Tradicional

ABORDAGEM TRADICIONAL: Considera-se aqui uma abordagem do processo ensino-aprendizagem que não se fundamenta implícita ou explicitamente em teorias empiricamente validadas, mas numa prática educativa e na sua transmissão através dos anos

Escola: A escola, fundada nas concepções dessa abordagem, é o lugar por excelência onde se realiza a educação, a qual se restringe, em sua maior parte, a um processo de transmissão de informações em sala de aula e funciona como uma agência sistematizadora de uma cultura complexa.

Ensino-aprendizagem: A ênfase é dada às situações de sala de aula, onde os alunos são "instruídos" e "ensinados" pelo professor. Comumente, pois, a instrução subordina-se à educação, considerando a aprendizagem do aluno como um fim em si mesmo: os conteúdos e as informações têm que ser adquiridas, os modelos imitados.

Professor-aluno: A relação professor-aluno é vertical, sendo que um dos polos (o professor) detém o poder decisório sobre a metodologia, conteúdo, avaliação, forma de interação na aula, etc. Ao professor compete informar e conduzir seus alunos em direção a objetivos que lhes são externos, por serem 
escolhidos pela escola e/ou pela sociedade em que vivem e não pelos sujeitos do processo.

Metodologia: Caracterizado o ensino pela transmissão do patrimônio cultural, pela confrontação com modelos e raciocínios elaborados, a correspondente metodologia se baseia mais frequentemente na aula expositiva e nas demonstrações do professor à classe, tomada quase como auditório.

Avaliação: A avaliação é realizada predominantemente visando a exatidão da reprodução do conteúdo comunicado em sala de aula. Mede-se, portanto, pela quantidade e exatidão de informações que se consegue reproduzir. Daí a consideração de provas, exames, chamadas orais, exercícios, etc., que evidenciam a exatidão da reprodução da informação.

Fonte: ARAÚJO, Marciano V. Baseado das Informações dos estudos de Émile Chartier (1978)

O quadro contém definição da abordagem tradicional e os elementos didáticos a ela ligados. Agora, o que se segue, estaremos colocando a definição e os elementos didáticos ligados a abordagem comportamentista fundada por ${ }^{12}$ Jonh B. Watson, essa abordagem entende que o desenvolvimento da habilidade é determinado pela sua relação com o meio em que se encontra.

Quadro 10: Informações da Abordagem Comportamentalista

Abordagem Comportamentista: Os comportamentalistas ou behavioristas, assim, como os denominadores instrumentalistas e os positivistas lógicos, consideram a experiência ou a experimentação planejada como a base do conhecimento. Evidencia-se, pois, sua origem empirista, ou seja, a consideração de que o conhecimento é o resultado direto da experiência.

A escola é considerada e aceita como uma agência educacional que deverá adotar forma peculiar de controle, de acordo com os comportamentos que pretende instalar e manter. Cabe a ela, portanto, manter, conservar e em parte 
modificar os padrões de comportamento aceitos como úteis e desejáveis para uma sociedade, considerando-se um determinado contexto cultural. A escola atende, portanto, aos objetivos daqueles que lhe conferem o poder.

Ensino-aprendizagem: Para os behavioristas, a aprendizagem pode ser defendida como uma mudança relativamente permanente em uma tendência comportamental e/ou na vida mental do indivíduo, resultantes de uma prática reforçada (Rocha, 1980, p.28)

Professor-aluno: Segundo essa abordagem, o professor teria a responsabilidade de planejar e desenvolver o sistema ensino-aprendizagem, de tal forma que o desempenho do aluno seja maximizado, considerando-se igualmente fatores tais como a economia de tempo, esforços e custos.

Metodologia: É uma categoria bastante ampla nessa abordagem, pois aqui se incluem tanto as aplicações das tecnologias educacionais e estratégias de ensino, quanto as formas de reforço no relacionamento professor-aluno. Não se pretende exaurir as aplicações, mas apenas situar as principais decorrências de tal tipo de abordagem para consideração de situações de ensino concretas

Avaliação: Decorrente do pressuposto de que o aluno progride em seu ritmo próprio, em pequenos passos, sem cometer erros, a avaliação consiste, nesta abordagem, em se constatar se 0 aluno aprendeu e atingiu os objetivos propostos quando o programa foi conduzido até o final de forma adequada.

Fonte: ARAÚJO, Marciano V. Baseado nas Informações da proposta skinneriana

Destacaremos agora a abordagem que considera as tendências ou enfoques, encontradas predominantemente no sujeito. Como as anteriores, estará no quadro a definição e os elementos didáticos a ela ligados. Vejamos então, a abordagem humanista. 
Quadro 11: Informações da Abordagem Humanista

Abordagem Humanista: Essa abordagem dá ênfase a relações interpessoais e ao crescimento que delas resulta, centrado no desenvolvimento da personalidade do indivíduo, em seus processos de construção e organização pessoal da realidade, e em sua capacidade de atuar como uma pessoa integrada.

A escola: É decorrente de tal posicionamento será uma escola que respeite a criança tal qual é, e ofereça condições para que ela possa desenvolver-se em seu processo de que ela virá a ser. É uma escola que oferece condições que possibilitam a autonomia do aluno.

Ensino/Aprendizagem: Ensino centrado na pessoa implica técnicas de dirigir sem dirigir, ou seja, dirigir a pessoa à sua própria experiência para que dessa forma, ela possa estruturar-se e agir. Esta é a finalidade do método não diretivo.

Professor/aluno $\mathbf{O}$ professor é, primariamente, uma personalidade única. É considerado como um único ser humano que aprendeu a usar-se efetiva e eficientemente para realização de seus próprios propósitos e da sociedade, na educação dos outros.

Metodologia: As estratégias instrucionais, nessa proposta, assumem importância secundária. Não se enfatiza técnica ou método para se facilitar à aprendizagem. A característica básica dessa abordagem, no que se refere ao que ocorre em sala de aula, é a ênfase atribuída à relação pedagógica, a um clima favorável ao desenvolvimento das pessoas, ao desenvolvimento de um clima que possibilite liberdade para aprender.

Avaliação: Tanto em Rogers como em Neill, encontra-se um desprezo por qualquer padronização de produtos de aprendizagem e competências do 
professor. Rogers defende a autoavaliação. Considera algumas proposições referentes ao processo de avaliação (1972).

Fonte: ARAÚJO, Marciano V. Baseado nos estudos de Carl Rogers

Descreveremos no próximo quadro as características gerais, mas, sucinta da abordagem cognitivista, onde o termo "cognitivista" se refere a psicólogos que investigam os denominados "processos centrais" do indivíduo, dificilmente observáveis, tais como: organização do conhecimento, processamento de informações, estilos de pensamento ou estilos cognitivos, comportamentos relativos à tomada de decisões.

Quadro 12: Informações da Abordagem Cognitivista

Abordagem cognitivista: Uma abordagem cognitivista implica, dentre outros aspectos, estudar cientificamente a aprendizagem como sendo mais que um produto do ambiente, das pessoas ou fatores que são externos ao aluno. Existe ênfase em processos cognitivos e na investigação científica separada dos problemas sociais contemporâneos. As emoções são consideradas em suas articulações com o conhecimento.

Escola: Segundo Piaget, a escola deveria começar ensinando a criança a observar. A verdadeira causa dos fracassos da educação formal, diz, decorre essencialmente do fato de se principiar pela linguagem (acompanhada de desenhos, de ações fictícias ou narradas etc.) ao invés de fazê-lo pela ação real e material.

Ensino e Aprendizagem: Um ensino que procura desenvolver a inteligência deverá priorizar as atividades do sujeito, considerando-o inserido numa situação social. A concepção piagetiana de aprendizagem tem caráter de abertura e comporta possibilidades de novas indagações.

Professor-Aluno: As implicações para uma ação do professor e do aluno ficam claras nas categorias anteriores, evidenciando que ambos os polos da relação 
devem ser compreendidos de forma diferente da convencional, no sentido de um transmissor e um receptor de informação. Caberá ao professor criar situações, propiciando condições onde possam se estabelecer reciprocidade intelectual e cooperação ao mesmo tempo moral e racional.

Metodologia: Não existe um modelo pedagógico piagetiana. 0 que existe é uma teoria do conhecimento, de desenvolvimento humano que traz implicações para o ensino. Uma das implicações fundamentais é a de que a inteligência se constrói a partir da troca do organismo com o meio, por meio das ações do indivíduo. A ação do indivíduo, pois, é o centro do processo e o fator social ou educativo constitui uma condição de desenvolvimento.

Avaliação: A avaliação terá de ser realizada a partir de parâmetros extraídos da própria teoria e implicará verificar se 0 aluno já adquiriu noções, conservações, realizou operações, relações etc. $O$ rendimento poderá ser avaliado de acordo com a sua aproximação a uma norma qualitativa pretendida.

Fonte: ARAÚJO, Marciano V. Baseado nos estudos de Jean Piaget

Salientaremos no quadro a seguir as características da abordagem sociocultural. Uma das obras que se refere a esse tipo de abordagem e enfatiza aspectos sociopolíticoculturais, mais significativas no contexto brasileiro, é a de Paulo Freire, esse autor se preocupava com a cultura popular.

Paulo Freire defende em sua abordagem sociocultural que são sujeitos principais homem e mundo onde o homem é sujeito da educação. Diz ainda que se evidencia na abordagem uma tendência interacionista, já que há interação homem-mundo, sujeito-objeto, sendo imprescindível para que o ser humano se desenvolva e se torne sujeito de suas práxis. 
Quadro 13: Informações sobre a Abordagem Sociocultural

Abordagem Sociocultural: Esse movimento tem se voltado frequentemente, por exemplo, para as camadas socioeconômicas inferiores, e uma das tarefas tem sido a alfabetização de adultos. Parte sempre do que é inerente ao povo, sobretudo do que as pessoas assimilaram como sujeitos, não thes fornecendo, portanto, coisas prontas, mas procurando trazer valores que são inerentes a essas camadas da população e criar condições para que os indivíduos os assumam e não somente os consumam

Escola: Na obra de Paulo Freire, a educação assume caráter amplo, não restrita à escola em si e nem a um processo de educação formal. Caso a escola seja considerada, deve ser ela um local onde seja possível o crescimento mútuo, do professor e dos alunos, no processo de conscientização, o que implica uma escola diferente da que se tem atualmente, com seus currículos e prioridades.

Ensino e Aprendizagem: Uma situação de ensino-aprendizagem, entendida em seu sentido global, deverá procurar a superação da relação opressoroprimido. A superação deste tipo de relação exige condições tais como: reconhecer-se, criticamente, como oprimido engajando-se nas práxis libertadoras, onde o diálogo exerce papel fundamental na percepção da realidade opressora; solidarizar-se com o oprimido, o que implica assumir a situação e lutar para transformar radicalmente a situação objetiva, entendida como a transformação da situação concreta que gera a opressão (tarefa histórica dos homens).

Professor/Aluno: A relação professor-aluno é horizontal e não imposta. Para que o processo educacional seja real é necessário que o educador se torne educando e o educando, por sua vez, educador. Quando esta relação não se efetiva, não há educação. 
Metodologia: 0 método de alfabetização elaborado por Paulo Freire reflete sua abordagem sobre educação. Neste método, a codificação inicial consiste numa espécie de figura, um desenho representativo de uma situação existencial real ou constituída pelos alunos. Ao elaborar essa representação, os alunos realizam uma operação de distanciamento do objeto cognoscível. Desta forma, professor e alunos poderão refletir conjuntamente de forma crítica sobre os objetos que os mediatizam.

Avaliação: A verdadeira avaliação do processo consiste no auto avaliação e/ou avaliação mútua e permanente da prática educativa por professor e alunos. Qualquer processo formal de notas, exames, etc. deixa de ter sentido em tal abordagem. No processo de avaliação proposto, tanto os alunos como os professores saberão quais suas dificuldades, quais seus progressos. "A avaliação é da prática educativa, e não de um pedaço dela" (Freire, 1982, p.94).

Fonte: ARAÚJO, Marciano V. Baseado nos estudos de Paulo Freire

As abordagens colocadas são norteadas pelas concepções das tendências pedagógicas brasileira com a forma de como é compreendido o processo de ensinoaprendizagem definido ao longo da história.

Sabemos que muitas vezes, os professores de uma instituição educacional utilizam processos pedagógicos diferentes, havendo assim, uma mescla de tendências usadas.

Salientamos que o conhecimento das tendências educacionais, das abordagens pedagógicas, paradigmas, sistemas educacionais e a história da educação são primordiais para a formação de docentes, assim como os currículos para basear sua prática pedagógica, sendo assim, seguiremos dissertando sobre tópicos importantíssimos para fundamentar o tema escolhido. 


\section{FORMAÇÃO, CURRÍCULO E PRÁTICA}

Sabemos que a formação de docentes estar associada a teoria e a prática pedagógica que o professor aplicará em sala de aula. Muitos estudiosos dentro de suas instrumentalizações a serem repassadas para os professores como forma de realizar mudanças significativas no processo educacional através de uma política de reconstrução da fundamentação da prática pedagógica.

É esse pensamento que queremos levar ao município de Aquiraz para que os professores compreendam que as formações são de fundamental importância para sua vida docente na transmissão de didáticas pedagógicas ao grupo de discentes qualificadamente.

Sabemos que a pratica docente não tem sido atrativo para profissionais, isso é comprovado pelo pequeno número de pessoas que procuram o curso de pedagogia, um dos pontos que merece destaque em relação a profissão de professor é a tão falada desvalorização dos profissionais de educação, assim, os indivíduos que entram nos cursos superiores, não escolhem o curso de pedagogia.

A área da pedagogia vem enfrentando problemas que vai desde um salário digno para o exercício de sua profissão, a preparação qualificada para sua atuação e o seu próprio exercício pedagógico, além da indisciplina dos educandos, eles têm mostrado um quadro de violência, são notícias constantes da mídia, esses fatos afastam pessoas que apresentam aptidões e didáticas de pedagogo, mas se distanciam pelas problemáticas citadas.

Além dos baixos salários, existem outros desafios para a prática docente é por esses motivos, que, professores já formados, se vêm obrigados a trabalharem em vários períodos, tendo que levar trabalhos para seu domicílio sem receber remuneração para isso.

Ainda tem um por menor ligado as atitudes mencionadas, tem a falta de dinheiro para investir em sua formação e tempo para ela, já que estão sobrecarregados, fatos que 
levam os professores sofrerem um processo de defasagem profissional mesmo sem querer que afetem seu desempenho didático junto ao grupo de educandos nas instituições que venham atuar.

Sabemos que os empecilho apresentados não devem desmotivar quem está na labuta da educação, pois, na própria escola os professores encontram alternativas para aperfeiçoar e melhorar suas práticas pedagógicas. O professor ao investigar o espaço da própria prática, encontra possibilidades de vivenciar bem seu exercício reflexivo.

Portanto, a prática pedagógica no espaço da sala de aula e a pesquisa feita pelo educador, pode emergir se acontecerem simultaneamente, através deles, interagem fazendo surgir uma ressignificação do conceito de professor, de aluno, de aula e de aprendizagem.

Com as formações e as constantes informações, o professor pode fazer do seu trabalho pedagógico em sala de aula, um espaço de transformação enquanto sujeito que não reproduz apenas, mas que produz seu conhecimento através de uma reflexão crítica de seu desempenho docente junto a seus discentes.

Ressaltamos que a formação de professor está intrinsicamente ligada a pesquisa, fazendo uma análise crítica da sua prática, o educador toma consciência de dimensões e questões que antes eram ignoradas, pois, a pesquisa é a construção de novos saberes e para realizá-la o professor precisa de tempo e dedicação.

Após tantas leituras, percebemos a defasagem profissional do município em pesquisa, as formações são importantes, disso temos convicção, mas, precisamos também de colocarmos em pratica as abordagens, as tendências, o currículo e didáticas inovadoras para conseguirmos a tão sonhada educação de qualidade.

$\mathrm{Na}$ figura abaixo, o esquema mostra a interligação de elementos para o êxito do processo de ensino-aprendizagem, pois, são essenciais para a educação, pois, estando esses elementos compactados, a qualidade da educação surgira imediatamente, mas, o que é ${ }^{13}$ currículo? Na formação de professores, o alunado recebe como definição de currículo, o colocado no rodapé. 
Figura 08: Esquema para uma boa Aprendizagem

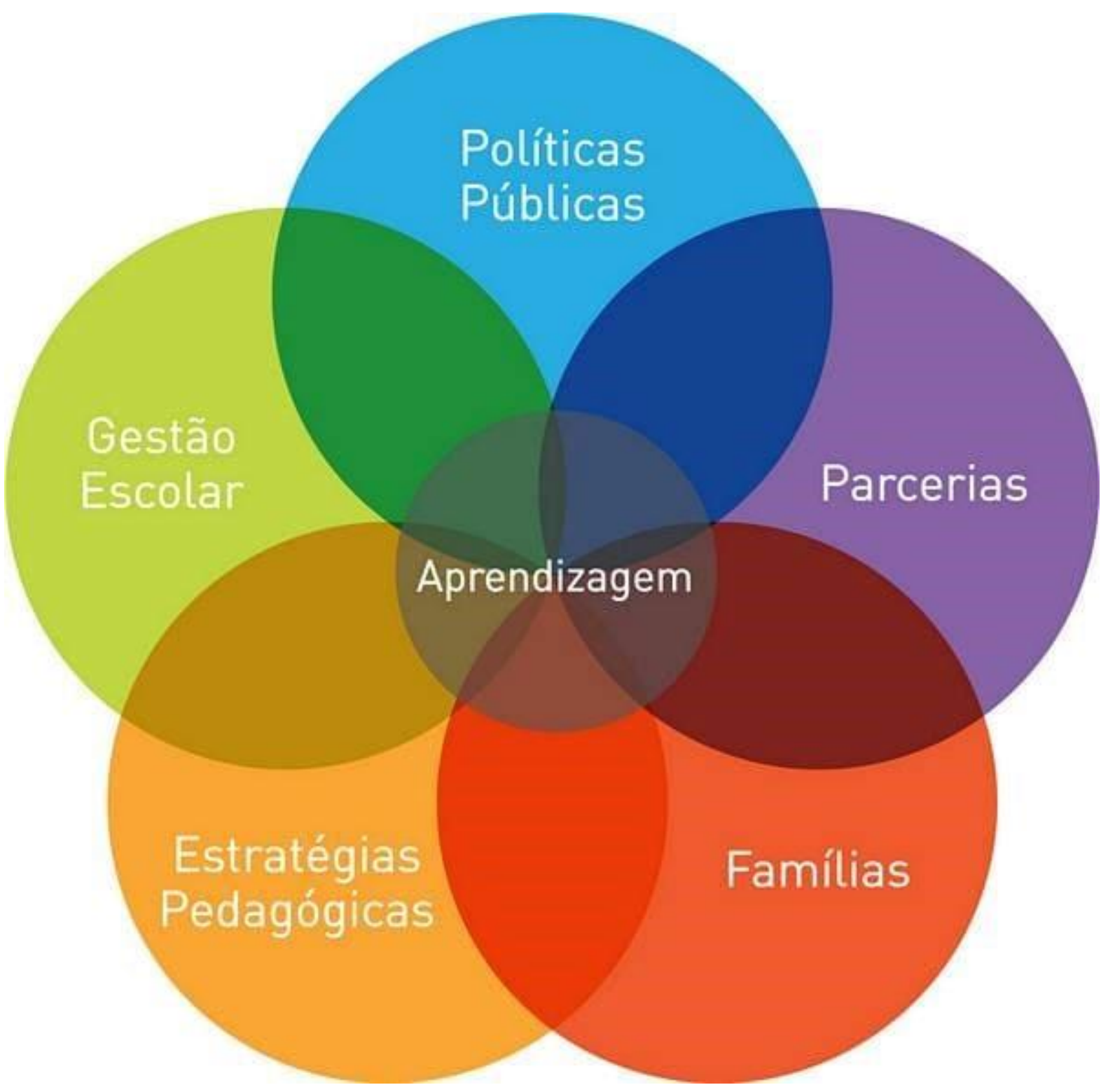

Fonte: ARAÚJO, Marciano V. Baseado nos estudos sobre práticas pedagógicas (2015)

Constatamos que verdadeiramente a formação do professor é fator imprescindível para sua pratica e para que a escola consiga alcançar melhores resultados, uma vez que o professor desenvolva em sua pratica cotidiana uma postura auxiliadora ao aluno para que ele tenha progresso dentro de um processo reflexivo e consciente para cumprimento de deveres e direitos dentro da sociedade. 
É notório a necessidade de uma relação harmoniosa entre todos os fatores descritos e inquestionável que a escola precisa ser inovadora para acompanhar as renovadas informações educacionais, ela (escola) precisa de uma sistematização no seu processo avaliativo.

Sem investimentos no tempo de estudo ou em cursos de aprofundamento para os professores, não havendo esse investimento, consequentemente não serão alcançados os objetivos satisfatórios no que se refere aos índices programados pelo sistema educacional, já que são os professores que assumem o papel de avaliadores de seus alunos, assim eles devem ter condições para avaliá-los.

Para Tardif (2002) a prática pedagógica está ligada a formação de professores, já que nelas são repassados os conhecimentos que os professores adquiriram nas formações docentes, ou seja, estão relembrando tendências, abordagem e o sistema educacional para assim melhorar metodologias que aplica no seu cotidiano pedagógico. Segundo o autor:

[...] a prática pode ser vista como um processo de aprendizagem por intermédio do qual os professores retraduzem sua formação e a adaptam à profissão [...]. A experiência provoca, assim, um efeito de retomada crítica (retroalimentação) dos saberes adquiridos antes ou fora da prática profissional (TARDIF, 2002, p. 53).

Segundo Pimenta (2002) a formação de professores precisa de uma profunda reflexão, elas precisam estar dentro das necessidades do docente para uma pratica de metodologias que venham favorecer o processo educativo a alcançar índices programados, pois o professor é o mais importante elo entre os conhecimentos historicamente construídos e os educandos que irão receber. Para esse autor:

Uma das demandas importantes dos anos noventa, em relação à atividade docente, é, justamente, repensar a formação inicial e continuada dos professores, a partir da análise das práticas pedagógicas docentes, ou seja, do cotidiano escolar (PIMENTA, 2002, p. 143). 
Para Oliveira (2004) a formação de professores vem dar uma dimensão a sua profissionalização e abre possibilidades de fazeres e saberes reflexivos baseados em estudos de teóricos sobre a função do professor no repasse dos conhecimentos e transformação dos educandos a partir dessa concepção. Segundo esse autor:

Desconsiderar essa dimensão da formação, ou mesmo a relegar a um segundo plano, é desacreditar na possibilidade de que o processo da formação de professores possa ser um espaço fértil e fecundo para unir fazeres e saberes, de forma reflexiva e instrumentalizar cada vez mais o educador como leitor e construtor da sua prática, da sua ação (OLIVEIRA, 2004, p. 138).

Segundo Lima (2001, p. 47), "a prática sempre esteve presente na formação do professor, seja pela observação, imitação de bons modelos, ou pela participação em contextos escolares".

O pensamento desse autor é parecido com a de Tardif; a prática deve ser contextualizada e, de certa forma, não manipulada pelo professor, uma vez que, a simples presença do aluno não é garantia da eficácia e da eficiência da prática profissional do professor.

Para Almeida (1994), em pleno anuncio da LDB, o dia a dia de sala de aula deve trazer conhecimento e motivação para os educandos, o conhecimento encorpado na didática pedagógica tirada de teóricos que direcionam para uma compreensão consciente da significação do real papel do professor. Portanto, ressaltamos que formação, currículo e pratica pedagógica são elementos fundamentações dentro do processo de ensinoaprendizagem. $\mathrm{O}$ autor menciona que:

[...] o cotidiano da sala de aula caracteriza-se como fonte inesgotável de conhecimentos, e desta fonte que deverão ser retirados os elementos teóricos que permitam compreender e direcionar uma ação consciente que procure superar as deficiências encontradas e recuperar o real significado do papel do professor, no sentido de apropriar-se de um 
"fazer" e de um "saber fazer" adequados ao momento que vive a escola atual (ALMEIDA, 1994, p. 39).

Todo educador tem a certeza que currículo e formação formam um dueto na sua pratica pedagógica, conhecer o currículo é levar para a compreensão de uma renovada pratica é dever do professor, pois ele é tido como mediador do saber educacional, naturalmente, o professor tem a trajetória com oportunidades de construir e reconstruir conhecimentos a partir de suas experiências formativas e profissionais.

Sabemos que os processos que constituem a educação como um direito universal, os pressupostos teóricos e filosóficos que ao longo da história da educação tem embasado e assegurado esse direito e ainda a democratização e o direito à educação no nosso país. Devemos compreender que o currículo é um importante instrumento de viabilização do direito à educação e tem como objetivos, segundo a LDB de:

- Identificar as principais teorias curriculares que explicam as diversas possibilidades de organização curricular de nossos sistemas de ensino;

- Analisar o currículo como espaço de poder, cultura, ideologia e hegemonia;

- Discutir criticamente as tendências atuais na organização curricular, tendo em vista as necessidades de aprendizagem dos educandos;

- Conhecer o processo e a organização das novas diretrizes curriculares nacionais, tendo em vista seus impactos na gesta da escola.

Devemos, portanto, repensar o currículo junto com a prática docente estar em função de acabar com as questões das desigualdades sociais. Assim vemos nos estudos de teóricos, propostas de revisão da lógica que estrutura os conhecimentos.

\section{A RELEVÂNCIA DAS FORMAÇÕES NAS PRÁTICAS COTIDIANAS NA ESCOLA}

As formações de professores são baseadas em estudos de grandes pesquisadores acerca das fases de desenvolvimento dos indivíduos, informações essas que levam 
os educadores traçarem suas didáticas pedagógicas de acordo com a clientela que irá atender.

Percebemos que Vygotsky, Wallon, Piaget, Emilia Ferreiro, Paulo Freire e outros pesquisadores, em seus estudos mostraram que o conhecimento, em primeiro lugar, se dá na troca, na interação, na socialização, com o cognitivo de cada indivíduo, informações que recebemos nas disciplinas acadêmicas, mas que são reforçadas nas formações de professores e levamos para as salas de aulas no cotidiano da escola, independente da faixa etária que o educador irá trabalhar.

É importante salientarmos que o currículo corresponde ao que a escola decide em função das suas necessidades especificas e das metas e objetivos a serem alcançadas, sendo assim, o educador aproveita os conteúdos programáticos para favorecer a integração de conhecimentos, valores, atitudes e competências que venham valorizar sua pratica cotidiana e desenvolver a aprendizagem de seus educandos.

Outro autor que trata da questão das práticas cotidianas do professor é Dermeval Saviani, ele ressalta que "A escola é o local que deve servir para os interesses populares garantindo a todos um bom ensino e saberes que reflitam na vida dos alunos e os prepare para a vida adulta" (SAVIANI, 1987).

Saviani em sua obra "Escola e Democracia" ressalta que as teorias da educação e os problemas que são encontrados nas escolas não estão impedindo a marginalização da criança e essa marginalização se dá porque ela não tem acesso à escola e reforça que a marginalidade é a condição da criança excluída.

O pensamento de Saviani coloca a escola como instrumento de apropriação do saber e que ela pode contribuir para eliminar a seletividade e exclusão social, fato que deve ser levado em consideração, para erradicar as gritantes disparidades de níveis escolares, evasão escolar e marginalização. Assim, indagamos: Será que a escola tem desempenhado seu verdadeiro papel cotidianamente? 
Essa indagação é pertinente a nossa pesquisa, pois, de fato, a escola é o local que prepara a criança, futuro cidadão, para a vida, pelo menos deveria ser, portanto, a escola deve transmitir valores éticos e morais aos seus educandos para que eles cumpram com seus papeis de cidadãos dentro da sociedade da qual estão inseridos.

A escola não pode e não deve escolher seu grupo de alunado, ao recebê-los deve trabalhar verdadeiramente para transformá-los, esses conceitos, defendidos por Saviani que ressalta o poder social que a escola tem para com os alunos que assiste deve ser valorizado e o educador, recebe esse tipo de concepção, ao participar de formações continuadas que inovam suas práticas pedagógicas, por isso é relevante essas formações para o cotidiano do professor.

Por tudo que descrevemos em nosso trabalho de pesquisa, constatamos que é fundamental, como dizemos anteriormente, o conhecimento de tendências, abordagens, currículo e acima de tudo, o desenvolvimento das fases da criança, através desses saberes atenderemos qualificadamente nas crianças e os transformaremos em verdadeiros cidadãos cumpridores de seus deveres e conhecedores dos valores culturais e institucionais.

Nosso país é grande, mas infelizmente apresenta um rendimento médio e ainda possui várias regiões subdesenvolvidas. O sistema de educação brasileira está em conformidade e muitas deficiências atormentadas pelas disparidades regionais e raciais. O analfabetismo é mais elevado no Nordeste onde $19,9 \%$ da população é analfabeta. A seguir colocaremos uma tabela com dados do PNLD (2007).

Tabela 02: Índice de Desenvolvimento da Educação Básica (2009) por Região

\begin{tabular}{|l|l|l|l|}
\hline Região & $\begin{array}{l}\text { Anos iniciais do ensino } \\
\text { fundamental }\end{array}$ & $\begin{array}{l}\text { Anos finais do ensino } \\
\text { fundamental }\end{array}$ & $\begin{array}{l}\text { Ensino } \\
\text { Médio }\end{array}$ \\
\hline Sudeste & 5,3 & 4,3 & 3,8 \\
\hline $\begin{array}{l}\text { Centro- } \\
\text { oeste }\end{array}$ & 4,9 & 4,1 & 3,5 \\
\hline Nordeste & 3,9 & & 3,4 \\
\hline
\end{tabular}




\begin{tabular}{|l|l|l|l|}
\hline Norte & 3,8 & 3,6 & 3,3 \\
\hline Sul & 5,1 & 4,3 & 4,1 \\
\hline
\end{tabular}

Fonte: ARAÚJO, Marciano V. Baseado em dados da PNAD

A tabela mostra que a região nordeste precisa de políticas públicas que venha melhorar a educação dessa região e acabe de vez com o analfabetismo. Colocar a tabela foi importante para uma reflexão no que diz respeito as informações sobre a relevância das formações de professores para sua pratica cotidiana, vemos que a educação das creches anda de vento em polpa para a meta traçada pelo PNE, e as demais modalidades também, sem falar como a educação se desenvolve em cada região brasileira mostrada na tabela acima de 2007.

Esperamos que venham mais formações para qualificar nossos educadores. Saviani (1987) sobre aprendizagem, o autor coloca que ela só acontecerá se os sujeitos envolvidos exercerem seus papeis adequadamente. Vejamos o pensamento de Saviani:

Aprender é desenvolver a capacidade de processar informações e organizar dados resultantes de experiências ao passo que se recebe estímulos do ambiente. O grau de aprendizagem depende tanto da prontidão e disposição do aluno quanto do professor e do contexto da sala de aula. Como passo inicial o professor precisa verificar aquilo que o aluno já sabe por procurar escutar e observar. $\mathrm{O}$ aluno por sua vez procura compreender o que o professor tenta explicar. Quando ocorre a transferência de aprendizagem significa que o aluno conseguiu sintetizar as informações e passou a ter uma visão mais clara superando assim sua visão confusa e parcial (SAVIANI, 1987, p. 134)

Ao tratarmos sobre as práticas pedagógicas no cotidiano para transformação do indivíduo que frequenta a escola, é importante ressaltar que aprendizagem se dá a medida que os envolvidos tenham motivação na execução de seus papeis, é o que o pensamento de Saviani, acima colocado, quis dizer, já Delors diz que: "A 
aprendizagem torna-se um elemento essencial durante toda a vida do indivíduo" (DELORS, 2005, p.25).

Ao adquirir aprendizagem, o indivíduo transforma modos de vida e relação social, pensamento que vai de encontro ao de Saviani ao reforçar que a melhoria do ser humano se dá através da educação recebida e que os sistemas educacionais precisam constantemente de políticas reformuladas que levem os educandos a prosperarem.

Infelizmente as pesquisadas realizadas, mostraram que as reformas educacionais acontecem, mas vem de encontro aos interesses da classe dominante, vejamos o

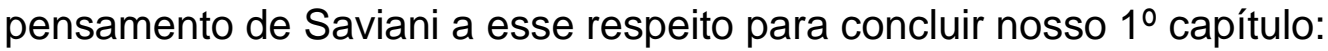

Enquanto os interesses educacionais não beneficiarem o povo, que verdadeiramente necessita deles para melhorar sua situação perante a sociedade, a educação brasileira não avançará, em termos de melhora qualitativa, pois as políticas públicas para a educação nacional não visam outro alvo senão interesses políticos, que buscam evitar qualquer reformulação que possam fazer o povo prosperar, e prejudicar o poder (SAVIANI, 1987, p. 132)

\section{CAPÍTULO}

\section{FORMAÇÃO DOCENTE NO BRASIL}

Sabemos que o professor exerce papel fundamental na transmissão de conhecimentos para seus discentes. Para ser um bom educador, os docentes impactam no projeto educacional de qualquer nação para transmissão de saberes através de suas práticas pedagógicas.

Em nossa contemporaneidade as mudanças constantes nas formas de aprender e ensinar dos cursos de licenciatura preparam os futuros professores para um diálogo com a nova realidade das salas de aula das escolas públicas e particulares onde eles atuam como mediadores e principal ator da aprendizagem do processo educacional. 
Percebemos que os professores se fortalecem com as formações continuadas para lidar com o sistema educacional do cotidiano, esse, com tantos desafios e dificuldades que os discentes apresentam na hora da transmissão de conhecimentos pelos professores na tentativa de transformar esses educandos para que eles se enquadrem na sociedade qualificadamente.

Através das leituras que realizamos para fundamentação dessa pesquisa, constatamos que a prática pedagógica ultrapassa a simples aplicação de conteúdo, teoria aprendida ou mesmo de repetição de procedimentos metodológicos que docentes aprenderam nas cadeiras das faculdades.

Mas, como em toda profissão, o docente precisa de conhecimentos renovados pautados pelo currículo inovador repassados pelos aplicadores de formações com metodologias que levem nossos educandos a uma sabia transformação e aquisição do saber e cumprimento de deveres sociais e educacionais qualificadamente.

Devemos considerar que a cultura é um componente do ensino, ou seja, significa admitir que ela pertence aos conhecimentos/saberes docentes, envolvendo diferentes categorias, por essa razão é que devemos valorizar a cultura e repassa-la de maneira significativa para que os educandos se identifiquem culturalmente dentro dos conhecimentos e saberes a eles ensinados pelos docentes.

Norteados pelos autores colocados no quadro abaixo, elaborado com base nos estudos de Leme, (2006, p. 26) que reuniu quatro autores, com diferentes obras, divididos em duas categorias para entendimento de seus estudos, as categorias segundo Leme (2006) seriam:

a. Os conhecimentos advindos durante a formação inicial,

b. Os produzidos com a prática profissional.

Quadro 14: Fases do Conhecimento da Formação de Professores

\section{Categorias de conhecimentos dos professores}




\begin{tabular}{|c|c|c|}
\hline Autores & $\begin{array}{l}\text { Conhecimento advindo } \\
\text { durante a formação inicial }\end{array}$ & $\begin{array}{l}\text { Conhecimentos produzidos } \\
\text { com a prática profissional }\end{array}$ \\
\hline \multirow{3}{*}{$\begin{array}{l}\text { Pimenta } \\
(1996, \text { p. } 72-82)\end{array}$} & \multicolumn{2}{|l|}{ Saberes científicos } \\
\hline & \multicolumn{2}{|l|}{$\begin{array}{l}\text { Saberes didáticos e } \\
\text { pedagógicos }\end{array}$} \\
\hline & & Saberes da prática \\
\hline \multirow{4}{*}{$\begin{array}{l}\text { Pórlan } \\
\text { (1997, p. 155-171) }\end{array}$} & \multicolumn{2}{|l|}{ Saberes acadêmicos } \\
\hline & & $\begin{array}{l}\text { Saberes baseados na } \\
\text { experiência }\end{array}$ \\
\hline & & Rotinas e guias das ações \\
\hline & & Teorias implícitas \\
\hline \multirow{7}{*}{$\begin{array}{lr}\text { Shulman } & \text { apud } \\
\text { Garcia } & (1997: 1997: \\
93-114) & \end{array}$} & \multicolumn{2}{|l|}{$\begin{array}{l}\text { Conhecimento dos } \\
\text { conteúdos }\end{array}$} \\
\hline & \multicolumn{2}{|l|}{$\begin{array}{l}\text { Conhecimento pedagógico } \\
\text { gera }\end{array}$} \\
\hline & \multicolumn{2}{|l|}{$\begin{array}{l}\text { Conhecimento pedagógico } \\
\text { do conteúdo }\end{array}$} \\
\hline & \multicolumn{2}{|l|}{$\begin{array}{l}\text { Conhecimento dos fins e } \\
\text { dos propósitos educativos }\end{array}$} \\
\hline & \multicolumn{2}{|l|}{ Conhecimento do currículo } \\
\hline & & $\begin{array}{l}\text { Conhecimento do contexto } \\
\text { educativo }\end{array}$ \\
\hline & & $\begin{array}{l}\text { Conhecimento dos alunos e } \\
\text { das suas características }\end{array}$ \\
\hline \multirow[t]{4}{*}{$\begin{array}{l}\text { Elbaz apud Pacheco } \\
\text { (1995) }\end{array}$} & $\begin{array}{l}\text { Conhecimento dos } \\
\text { conteúdos escolares }\end{array}$ & \\
\hline & Conhecimento da instrução & \\
\hline & \multicolumn{2}{|l|}{ Conhecimento de si próprio } \\
\hline & $\begin{array}{ll}\text { Conhecimento } & \text { do } \\
\text { desenvolvimento } & \text { do } \\
\text { currículo } & \end{array}$ & \\
\hline
\end{tabular}


Conhecimento do contexto do ensino

Fonte: ARAÚJO, Marciano V. de. Baseado dos estudos de Leme (2006)

O quadro mostra os conhecimentos dos docentes de acordo as formações recebidas. Segundo Oliveira (2010): "a atração de profissionais para o ingresso na carreira docente é um dos primeiros entraves para a formação inicial em nosso país".

A pesquisadora em questão, quer mostrar que a transformação dos educandos depende de uma boa formação dos docentes, pois, são eles os transformadores dos indivíduos que frequentam uma instituição de ensino.

É esse pensamento que desejamos levar para o quadro de docentes do município pesquisado para com eles, se sobressaia na prática de suas didáticas dentro do processo de ensino e aprendizagem reforçado com as formações de professores recebidas.

Notoriamente, já se tornou discussão trivial de que a qualidade da educação depende de haver pertinência e sintonia entre fatores essenciais como investimentos em estrutura física, pedagógica e tecnológica, porém, o que não se questiona mais é a importância da competência dos profissionais que atuam na área, pois, são os atores principais do processo de ensino e aprendizagem.

Ao tratarmos sobre a formação docente no Brasil, colocamos vários fatores envolvidos para uma educação qualificativa em nosso país, abaixo, com dados fornecidos pelo INEP, em seu site, colocaremos uma tabela com informações sobre matrículas de graduações no Brasil de 2002 a 2013 nas regiões brasileiras. 
Tabela 3 - Matriculas absolutas em cursos de graduaçäo presenciais e crescimento de 2001 a 2013

\begin{tabular}{|c|r|r|r|r|c|}
\hline & \multicolumn{1}{|c|}{2002} & \multicolumn{1}{c|}{2006} & \multicolumn{1}{c|}{2010} & \multicolumn{1}{c|}{2013} & Crescimento 2002-2013 \\
\hline Brasi & 3.479 .913 & 4.676 .646 & 5.449 .120 & 6.152 .405 & $76,80 \%$ \\
\hline Norte & 190.111 & 280.554 & 352.358 & 423.565 & $122,80 \%$ \\
\hline Nordeste & 542.409 & 796.140 & 1.052 .161 & 1.287 .552 & $137,38 \%$ \\
\hline Sudeste & 1.746 .277 & 2.333 .514 & 2.656 .231 & 2.903 .089 & $66,24 \%$ \\
\hline Sul & 677.655 & 854.831 & 893.130 & 962.684 & $42,06 \%$ \\
\hline Centro-0este & 323.461 & 411.607 & 495.240 & 575.515 & $77,92 \%$ \\
\hline
\end{tabular}

Fonte: Elaborado por autora a partir de dados do INEP

Fonte: Autor.

Com a aprovação da Lei de Diretrizes e Bases da Educação Nacional - LDB, em 1996 e do PNE - Plano Nacional de Educação, em 2001, a formação docente foi contemplada em capítulos próprios.

As citadas Leis trazem ações implementadoras com funções das determinações e prazos que interferem radicalmente no perfil do docente e no sistema educacional em todas as modalidades de ensino.

A formação do docente e sua condução de sala de aula qualificadamente é um dos objetivos da LDB em seu artigo 62, pois esse estabelece a formação mínima para o exercício do magistério. Vejamos esse Art.

A formação de docentes para atuar na educação básica far-se-á em nível superior, em curso de licenciatura, de graduação plena, em universidades e institutos superiores de educação, admitida, como formação mínima para o exercício do magistério na educação infantil e nas quatro primeiras séries do ensino fundamental, a oferecida em nível médio, na modalidade Normal (LDB, 1996, Art. 62).

Podemos verificar que nos últimos anos, segundo dados do MEC, há um desenvolvimento significativo de novas instituições e cursos, promovendo uma 
dinâmica intensa pelo acesso à formação de docentes em nosso país, fato que contradiz informações colocadas em nosso primeiro capítulo onde colocamos que os cursos de magistérios eram os menos procurado.

Perceber na história educacional brasileira, retratando a realidade do profissional para atuar na educação, fatores que Ihes são desfavoráveis, vejamos: tem acontecido um longo e contínuo processo de desvalorização dos governos e da sociedade, esse fato é comprovado pelo comportamento desrespeitoso dos educandos no ambiente escolar para com o docente.

Em função do fato acima citado, o professor tenta relevar sua desvalorização e exercer com maestria sua docência, mas é desmotivador para esse profissional a falta de prestigio e os baixos salários que Ihes são oferecidos, sem falar na evasão e rotatividade de docente titulado que teve um crescimento, esse fato abriu espaço para a contratação de professores leigos.

Esses leigos atuam sem a devida formação em algumas das regiões brasileiras. Indagamos: Quem perde com isso? Naturalmente que é a educação, pois, só através da legalidade de uma formação, docentes conseguirão transformar uma nação.

Ao mostrar nessa pesquisa a atual realidade educacional brasileira em referência a formação docente e suas prerrogativas legais e institucionais é que vem a problemática de pesquisarmos as questões da relevância da formação de professores já que através dela é que vem as inovações referente ao saber:

Assim indagamos: Por que os professores do município de Aquiraz não têm interesses nas formações dadas pelos técnicos da Secretaria de Educação? Constatamos que os técnicos tentam melhorar o processo educacional trazendo nas formações, muitas informações e estudos de teóricos relacionados ao processo educativo, pelo menos, é isso que percebemos ao participamos das formações de professores no citado município.

Ao descrevermos sobre observações realizadas nas formações do município pesquisado, para adquirirmos informações e relacionarmos a problemática levantada 
é que a seguir colocaremos a constituição histórica da formação superior docente no Brasil fundamentada em pesquisadores e documentos oficiais, com ela reforçaremos a vital importância das formações no exercício do docente em suas práticas pedagógicas.

Nossa pesquisa, reforça para a compreensão de métodos aliados a prática pedagógica que trarão desenvolvimento para o grupo estudantil do processo de ensino e aprendizagem e que as informações transmitidas nas formações de professores melhoram sua prática didática, levando-os a uma atualização necessária para a profissão que exerce.

Sabemos que a formação de professores no Brasil é permeada por vários períodos históricos, contamos um pouco no capitulo I, através dos estudos realizados constatamos que o desenvolvimento da educação superior demorou a ser implantado os primeiros cursos superiores, até o controle para autorização e funcionamento de faculdades e universidades, mas que, nos últimos anos houve um crescimento descontrolado desses em nosso país.

Queremos mostrar no desenvolvimento desse tópico algumas considerações para melhor entendimento do tempo e espaço, como já mencionamos, da trajetória da educação superior brasileira e sua importância na formação docente no território brasileiro, detalharemos sua criação e evolução posteriormente.

Vimos que a criação dos primeiros cursos superiores ocorreu com a transferência da família real portuguesa para o Brasil, no limiar do século XIX, esses primeiros cursos foram nas áreas de: medicina, engenharia e jurídica.

\section{CONSTITUIÇÃO HISTÓRICA DA FORMAÇÃO SUPERIOR DOCENTE NO BRASIL}

Para entendermos a educação superior de um modo global é necessário colocarmos um breve histórico, a evolução, os números, as leis e normas que regem a educação superior e, como acontece o processo de formação docente nas instituições de ensino 
superior brasileiras, fatos importantes para relacionarmos ao currículo e as práticas docentes.

Nosso estudo nos levou a seguinte informação: a educação superior brasileira e seu desenvolvimento, como mencionado, é permeada por momentos que vão desde a demora na implantação dos primeiros cursos superiores em nosso país.

Seu controle para autorização e funcionamento das novas faculdades e universidades, haja vista o crescimento descontrolado dos últimos anos da população, sendo necessário criação de mais cursos superiores.

Entendemos que a problemática do processo de formação docente entre teoria e prática pedagógica não se trata de um problema pontual, nem mesmo simples é bem mais complexa do que pensamos. Para fundamentar esse pensamento vejamos o que nos mostra Trojan (2008) dentro da historicidade dessa relação:

Historicamente, a relação entre teoria e prática no processo de formação docente tem se apresentado como um processo de difícil solução. Ainda que se busque a prática como fundamento da teoria e meio de conhecimento da realidade, as práticas de ensino em geral se mostram como meros campos de aplicação da teoria (TROJAN, 2008, p. 30).

Percebemos nessa citação que se faz necessário refletirmos sobre algumas considerações para melhor localizar no tempo e no espaço, a trajetória da educação superior brasileira e sua importância na formação docente de nosso país relacionada ao currículo e sua prática pedagógica, já que são processos intrinsicamente ligados.

Para Pimenta e Lima (2006): "é preciso afastar a compreensão da prática de ensino, como sendo a parte pratica do curso de formação docente". Vemos no pensamento das autoras que é preciso haver um estreitamento da relação entre teoria e prática, com ele, uma qualidade no que se refere o processo de ensino e aprendizagem, assim formar qualificadamente nosso grupo de estudantis. Para as atoras o processo de formação é: 
[...] o papel das teorias é o de iluminar e oferecer instrumentos e esquemas para análise e investigação, que permitam questionar as práticas institucionalizadas e as ações dos sujeitos, e ao mesmo tempo, se colocar elas próprias em questionamento, uma vez que as teorias são explicações sempre provisórias da realidade (PIMENTA; LIMA, 2006, p. 12).

Falar da historicidade da formação docente é lembrar o que disse Freire (1996) ao expressar sobre a educação como transmissora de conhecimentos e aquisição de consciência do seu papel dentro da sociedade. Freire (1996) diz que:

O ensinar não se limita apenas em transmitir conhecimentos, senão também no desenvolvimento da consciência de um ser humano inacabado em que o ensinar se torna um compreender a educação como uma forma de intervir na realidade da pessoa e do mundo (FREIRE, 1996, p. 54).

De acordo com Demo (2000) pesquisador do papel do professor como transformador do contexto educacional ele menciona que o professor é o sujeito da educação que aprende a aprender para assim transmitir o que aprendeu dentro do contexto educacional que atua. Esse autor ressalta que:

A pedra de toque da qualidade educativa é o professor visto como alguém que aprende a aprender, alguém que pensa, forma-se e informase, na perspectiva da transformação do contexto em que atua como profissional da educação (DEMO, 2000, p. 36).

Vemos no pensamento de Demo a importância do professor como profissional da educação sendo mediador da transformação dos educandos no que diz respeito ao cumprimento de seus direitos e deveres. Para mostrar a formação docente com seus aspectos normativos e as características da profissionalização além da relação entre a formação e a profissionalização colocaremos os caminhos legais. 
Ressaltaremos as últimas décadas do século $\mathrm{XX}$ onde acontecia um conjunto de movimentos sociais se mobilizando em prol de uma educação voltada para a transformação social e buscamos no texto constitucional de 1988, a firmação de atendimento aos anseios da sociedade civil, ele assegurou a educação como um direito social, como um direito de todos e como um dever do Estado e da família. No capítulo III, Art. 205, a Constituição Federal Brasileira (CFB), ressalta que:

Art. 205. A educação, direito de todos e dever do Estado e da família, será promovida e incentivada com a colaboração da sociedade, visando ao pleno desenvolvimento da pessoa, seu preparo para o exercício da cidadania e sua qualificação para o trabalho (CF, 1988, Art. 205)

Importante ressaltar que o Art. 206 respalda os princípios do ensino educacional como meio de transformação do indivíduo dentro da sociedade da qual faz parte. Vejamos esses princípios na CF, capítulo III, art. 206:

Art. 206. O ensino será ministrado com base nos seguintes princípios:

I - Igualdade de condições para o acesso e permanência na escola;

II - Liberdade de aprender, ensinar, pesquisar e divulgar o pensamento, a arte e o saber;

III - Pluralismo de ideias e de concepções pedagógicas, e coexistência de instituições públicas e privadas de ensino;

IV - Gratuidade do ensino público em estabelecimentos oficiais;

V - Valorização dos profissionais da educação escolar, garantidos, na forma da lei, planos de carreira, com ingresso exclusivamente por concurso público de provas e títulos, aos das redes públicas; (Redação dada pela Emenda Constitucional nㅜㅜ 53, de 2006)

VI - Gestão democrática do ensino público, na forma da lei; 
VII - Garantia de padrão de qualidade.

VIII - Piso salarial profissional nacional para os profissionais da educação escolar pública, nos termos de lei federal. (Incluído pela Emenda Constitucional oㅜ 53, de 2006) (BRASIL, 1988, CF, Art. 206).

Nela também tem a discussão sobre a necessidade da formação do professor em múltiplas dimensões pessoal, histórica, política e social. Na LDB - Lei de Diretrizes e Bases da Educação - 9394, de 20 de setembro de 1996, entre outros aspectos, dispôs de forma específica sobre a formação dos profissionais da educação. Vamos verificar a antiga orientação no Art. 61 que diz:

Art. 61. A formação de profissionais da educação, de modo a atender aos objetivos dos diferentes níveis e modalidades de ensino e as características de cada fase do desenvolvimento do educando, terá como fundamentos:

I - A associação entre teorias e práticas, inclusive mediante a capacitação em serviço;

II - Aproveitamento da formação e experiências anteriores em instituições de ensino e outras atividades.

Art. 62. A formação de docentes para atuar na educação básica far-se-á em nível superior, em curso de licenciatura, de graduação plena, em universidades e institutos superiores de educação, admitida, como formação mínima para o exercício do magistério na educação infantil e nas quatro primeiras séries do ensino fundamental, a oferecida em nível médio, na modalidade Normal. (BRASIL, LDB, 1996).

Os artigos só mostram que a educação deve estar acima de tudo, pois, através dela é que o país se desenvolve, precisamos que as formações dos profissionais da educação tenham uma significação para a pratica docente, assim, a didática que eles apliquem aos docentes os formarão 
qualificadamente, os artigos mostram ainda que ao se formarem, os docentes estarão preparados para atuarem nas modalidades de ensino da educação infantil e nas quatro primeiras series do Ensino Fundamental.

Após a colocação desse Art. passamos para o ano de 2002, onde o CNE - Conselho Nacional de Educação, instituiu as Diretrizes Curriculares Nacionais para a Formação de Professores da Educação Básica, em nível superior, Curso de Licenciatura, de graduação plena. Em seu artigo 9, percebemos a articulação entre três termos de: formação e profissional ou ainda exercício profissional. Vejamos esse artigo:

A autorização de funcionamento e o reconhecimento de cursos de formação e o credenciamento da instituição decorrerão de avaliação externa realizada no locus institucional, por corpo de especialistas direta ou indiretamente ligados à formação ou ao exercício profissional de professores para a educação básica, tomando como referência as competências profissionais de que trata esta Resolução e as normas aplicáveis à matéria (CNE, 2002).

Chegamos ao ano de 2009, em 30 de janeiro do referido ano, foi publicado no DOU Diário Oficial da União a Política Nacional de Formação de Profissionais do Magistério da Educação Básica, esse é um período de tantas aprovações de normas ligadas as formações de professores, vemos tentativas de melhoramento do sistema educacional.

Refletindo sobre as colocações constatamos que o Documento do Conselho Nacional de Educação, destaca a importância do docente no processo educativo da escola e de sua valorização profissional, como a formação continuada, essa como componente essencial da profissionalização docente (BRASIL, 2009).

Mas, o que vemos é que em nossa atualidade, essa valorização não existe, e que o sistema educacional precisa de efetivação das normas determinadas nas Leis aprovadas sobre formação docente. 
Também no ano de 2009, a Lei 12.014 alterou o artigo 61da LDB, a mudança tinha como finalidade distinguir as categorias dos trabalhadores que devem ser considerados profissionais da educação, a alteração ocorreu no dia 06 de agosto e passou a vigorar com a seguinte redação:

[...] consideram-se profissionais da educação escolar básica os que, nela estando em efetivo exercício e tendo sido formados em cursos reconhecidos, são:

I - Professores habilitados em nível médio ou superior para a docência na educação infantil e nos ensinos fundamental e médio;

II - Trabalhadores em educação portadores de diploma de pedagogia, com habilitação em administração, planejamento, supervisão, inspeção e orientação educacional, bem como com títulos de mestrado ou doutorado nas mesmas áreas;

III - Trabalhadores em educação, portadores de diploma de curso técnico ou superior em área pedagógica ou afim (BRASIL, LDB, 2009a).

Sabemos que o maior questionamento por parte dos profissionais da educação é a sua desvalorização, ao contar a historicidade da formação do docente, chegamos ao ano de 2010 onde as Diretrizes Curriculares Nacionais Gerais para a Educação Básica, no seu parágrafo primeiro do artigo 57 da Resolução no 04 de 13 de julho e Parecer no 7/2010 está entre os princípios nacionais da educação, ele assim redigido e trata da valorização do docente. Vejamos:

$\S 1^{\circ}$ - A valorização do profissional da educação escolar vincula-se a obrigatoriedade da garantia de qualidade e ambas se associam a exigência de programas de formação inicial e continuada de docentes e não docentes, no contexto do conjunto de múltiplas atribuições definidas para os sistemas educativos, em que se inscrevem as funções do professor (CNE, 2010). 
A constante desvalorização para com o magistério, nos leva a uma análise das políticas de formação docente, essas apresentam dilemas, e, ao mesmo tempo se tornam grandes desafios para quem escolhe se formar professor. Os desafios mais visíveis colocaremos no quadro abaixo:

Quadro 15: Desafios da Formação Docente

a) fragmentação e dispersão das iniciativas, justificadas pela chamada "diversificação de modelos de organização da Educação Superior";

b) descontinuidade das políticas educacionais;

c) burocratismo da organização e funcionamento dos cursos no qual o formalismo do cumprimento das normas legais se impõe sobre o domínio dos conhecimentos necessários ao exercício da profissão docente;

d) separação entre as instituições formativas e o funcionamento das escolas no âmbito dos sistemas de ensino;

e) o paradoxo pedagógico expresso na contraposição entre teoria e prática, entre conteúdo e forma, entre conhecimento disciplinar e saber pedagógicodidático (Cf. Capítulo IX do livro "A pedagogia no Brasil: história e teoria", Capítulo IX, SAVIANI, 2008a, p. 119- 123);

f) jornada de trabalho precária e baixos salários.

Fonte: Poíesis Pedagógica - V.9, N.1 jan/jun.2011; pp.07-19

Percebemos nesses desafios uma implicação para a abertura de novas perspectivas com características que se contrapõem simetricamente aos desafios acima apresentados. Em nosso pensamento, as perspectivas prováveis seriam as apresentadas por Saviani (2008) quando descreveu: "A Pedagogia no Brasil: História e teoria". Vejamos essas perspectivas segundo o autor no quadro abaixo:

Quadro 16: Novas Perspectivas para a Educação

a. Contra a fragmentação e dispersão das iniciativas

b. Contra a descontinuidade das políticas educacionais 


\section{c. Contra o burocratismo da organização e funcionamento dos cursos,}

d. Contra a separação entre as instituições formativas e o funcionamento das escolas,

\section{e. Contra as várias formas de manifestação do paradoxo pedagógico,}

Fonte: (CFB. "A pedagogia no Brasil: história e teoria", Capítulo X, p. 125-132, SAVIANI, 2008a);

Nessa perspectiva, um dos aspectos que fortaleceu o Processo de Formalização da formação de professores foi a migração da sociedade camponesa europeia para a cidade, no período da Revolução Industrial no século XVII, XVIII, na Inglaterra.

Nesse período houve a necessidade da formalização e massificação da educação, que se manifestou pelo meio da criação de instituições escolares, com o intuito do letramento básico da população, essa ideia é fundamentada no pensamento de Saviani (2008). Saviani ressalta que:

A necessidade da formação docente já fora preconizada por Comenius, no século XVII; e o primeiro estabelecimento de ensino destinado à formação de professores teria sido instituído por São Batista de La Salle, em 1684, em Reims [...] (SAVIANI, 2008, p. 07)

Saviani mostra sobre a massificação da educação para a população menos favorecido, ascendeu-se com a finalidade de preparar a população para o mercado de trabalho, tão famosa era do tecnicismo, pois o país necessitava de mão-de-obra.

Essa mudança trouxe a necessidade de criar um sistema que viesse formar um conjunto de sujeitos encarregados de transmitir aos seus futuros alunos a instrução voltada para a produção, fato que favoreceria as indústrias que se expandiam.

Sobre essa era, Tanuri (2000) reforça esse pensamento acima colocado quando diz uma citação enfatizando que escolas que formavam docentes, estavam preocupadas em preparar esses profissionais para utilização de um método, segundo o autor: 
Antes que se fundassem escolas especificamente destinadas à formação de pessoal docente, encontra-se nas primeiras escolas de ensino mútuo - instaladas a partir de 1834 - a preocupação de não somente ensinar os professores as primeiras letras, mas de prepará-lo, instruindo-os do domínio do método (TANURI, 2000, p. 63).

Vamos nos deportar para o processo histórico da educação, esse possuía fatos que demonstraram como o contexto do educando foi totalmente rejeitado. Rejeitados quando foram considerados comparativamente a uma "folha em branco" até a sua chegada à escola.

Esse era o pensamento do conceito da teoria empirista, era o famoso ensino tradicional, nele, todo e qualquer conhecimento seria adquirido por meio da transmissão do professor, ou seja, nessa época o professor era considerado o mentor da sabedoria, os alunos não se manifestavam, ouviam e não questionavam.

Vemos assim que, os conhecimentos eram padronizados e dessa forma, naturalmente que o ensino conservava o modelo apresentado onde o aluno deveria se adequar a ele, da mesma forma que o professor não tinha autonomia para refletir sobre sua prática pedagógica, pois os modelos já eram definidos.

Esse modelo permaneceu durante um longo período histórico, visão equivocada, e assim, foram modificados os estudos das causas da má aprendizagem e consequentemente da formação social dos envolvidos no sistema educacional da época em questão.

Além disso, demonstram que o sistema educativo necessita de estudos, de embasamento científico e expansão dos seus resultados que viessem atender os objetivos traçados pelos cursos de formação docente.

Desta maneira, nos reportamos à formação de professores como uma possibilidade que pode proporcionar esta apropriação, pois, quem direcionará a realização de fato nas escolas são os próprios professores, assim, grupo de professores precisam estar 
constantemente em formações continuadas para melhoria de suas didáticas em sala de aula.

Como tudo que acontecia no mundo servia de modelo para o Brasil, vejamos o que o MEC no ano de 2005 nos forneceu dados estatísticos de que nenhuma outra fase da história de nosso país foi tão crescente a frequência das pessoas nas escolas, nas faculdades e universidades. Vejamos informações do MEC no quadro abaixo sobre número de matriculas no ensino médio:

Tabela 04: № de Matriculas no Ensino Médio

\begin{tabular}{|l|l|l|}
\hline Ano & Modalidade de Ensino & $\%$ \\
\hline 2001 & Ensino Médio & 8,4 milhões \\
\hline 2003 & Ensino Médio & 2 milhões \\
\hline 2005 & Ensino Médio & 58,9 milhões \\
\hline
\end{tabular}

Fonte: ARAÚJO, Marciano V. de Baseado nos dados fornecidos pelo MEC

A historicidade da formação superior no Brasil passa por constantes reformulações educacionais como vimos no decorrer da descrição desse trabalho, o quadro acima mostra a modalidade que faz a transição do educando do nível de ensino médio para o superior.

Falar de formação docente no Brasil nos reportamos ao pensamento de Libâneo (2001), esse autor em seu livro "Arte de Formar-se" diz que a formação docente é um investimento pessoal de busca de conhecimento, assim, para poder ensinar, o professor precisa estar imbuído de conhecimentos que advém por meio da formação que se vai profissionalizando pela pratica cotidiana.

Portanto, a capacitação do indivíduo para o trabalho docente se constitui em um ato educativo de criatividade e inovação. Esse pensamento, vai de novo ao encontro do discurso de Libâneo que ressalta sobre o desenvolvimento pessoal sendo traçado pelo próprio sujeito e que o educador deve ter o compromisso de transformar a sociedade em que ele exerce sua profissionalização, Libâneo (2001) diz que: 
Formar-se é tomar em suas mãos seu próprio desenvolvimento e destino num duplo movimento de ampliação de suas qualidades humanas, profissionais, religiosas e de compromisso com a transformação da sociedade em que se vive [...] é participar do processo construtivo da sociedade [...] na obra conjunta, coletiva, de construir um convívio humano e saudável (LIBANIO, 2001, pp. 13-14).

$\mathrm{Na}$ transcrição sobre a formação docente, percebemos que há uma cumplicidade entre os teóricos e essa formação, pois, a profissionalização se dispõe e se complementa na trajetória docente. Continuaremos o assunto no próximo tópico, descrevendo sobre os conhecimentos abordados na formação docente.

Portanto, eles estão presentes na prática educativa inter-relacionada e integrada, seja por meio de pesquisas de grupos ou de atividades afins que proporcionam uma ampliação de conhecimentos junto aos docentes que estão em constantes formações.

\section{CONHECIMENTOS ABORDADOS NA FORMAÇÃO DOCENTE}

Sabemos que no início do século XXI a prioridade da educação brasileira está pautada na formação inicial e continuada de professores, com esses fatores necessários para que os conteúdos da educação superior de professores para a educação básica, ministrada no Brasil tenha mudanças significativas, assim haverá uma qualificação no sistema educacional.

Com pressuposto de reconhecimento que a formação inicial é apenas um componente de uma estratégia que leva conhecimento e enorme profissionalização ao professor de educação básica, a formação é indispensável para a implementação de política de melhoria desse profissional.

As estruturas educacionais propõem a criação de um sistema nacional de certificação de competências docentes e a priorização da área de formação de professores nas políticas de incentivo, com efeito de incitar o desenvolvimento e financiamento do docente. 
Percebemos a urgência de reformulação da teoria e da prática da formação de professores no Brasil que já deu passos significativos nos anos 80,90 e nos tempos atuais para universalização do acesso ao ensino fundamental obrigatório. Vejamos alguns desses passos no quadro abaixo:

Quadro 17: Passos para Universalizar o Ensino Fundamental

\section{Melhorou o fluxo de matriculas;}

\section{Investimento da qualidade da aprendizagem do nível escolar;}

\section{Aumento do número de crianças de 6 anos ao sistema educacional;}

\section{Expansão do Ensino Médio.}

Fonte: ARAÚJO, M. V de. Baseado nos dados do MEC

Vemos nos passos traçados pelo MEC uma preocupação quanto a melhoria do ensino fundamental com a democratização do acesso e qualidade da educação básica provocada num contexto de uma modernização econômica, e, acima de tudo, pelo fortalecimento dos direitos da cidadania e disseminação das tecnologias da informação que impactam nas expectativas educacionais ao ampliar o reconhecimento da importância da educação na sociedade que tem no conhecimento um fator de desenvolvimento da população do Brasil.

Sabemos que o professor é o protagonista do sistema educacional diante das práticas educativas que exerce e as recebeu em sua formação profissional, sendo assim, ele é capaz de construir a si próprio e a todo momento repensar criticamente como estar exercendo sua prática diante das experiências cotidianamente vivenciadas.

Sendo assim, a formação do docente se constrói a cada dia e ele deve estar constantemente em formação. Vilela (2000) descreve o professor situando-o no processo de identidade da categoria docente da seguinte maneira:

[...] um profissional cuja competência vai além da aplicação correta de métodos de ensino e de materiais institucionais e do domínio de um conhecimento a ser transmitido ao aluno. O professor é um ator social, 
com uma função social determinada e, portanto, diretamente responsável pelos processos educativos institucionais. É, pois, um dos sujeitos centrais do processo pedagógico, considerado em sua subjetividade, sua identidade, seus valores, seus saberes e habilidades (VILELA, 2000, p. 02)

Vemos na citação de Vilela que em sua prática docente, o professor coloca sua competência transmitindo os saberes adquiridos por meio das atividades cotidianas que exerce na escola em função de transformar o educando para que esse se enquadre dentro da sociedade da qual faz parte.

Para tratarmos do conhecimento recebido pelo professor em sua formação docente, é pertinente colocarmos que a historicidade de formação desse tem sido alvo de muitas políticas de formação continuada, essa assumindo uma importância primordial para prática desse profissional.

Essas formações vêm aliadas as reformas curriculares, implementadas pelos diferentes governos ao longo da formação do povo brasileiro na tentativa de dar qualidade ao ensino, principalmente o público.

Nos programas e cursos oferecidos na formação docente, esses trazem divulgação de maneiras de pensar e de organizar o ensino ministrado pelo docente formado, e que ele leve em consideração as inovações traçadas pelas secretarias de educação da qual estão filiados para que assim, atenda qualificadamente o discente com que venha lidar cotidianamente. Mas, devemos ressaltar que a organização do tempo escolar, não são considerados como inserido em condições reais.

Analisando que a pratica docente envolve a constante reelaboração dos saberes que adquiri nas instituições onde se forma e que suas decisões pessoais em situações concretas, inusitadas, com que ele, docente se depara no âmbito da sala de aula, claro que, se faz necessário que esteja em formação cotidianamente. 
Portanto, percebemos que a prática pedagógica se torna formativa, pois, forma o professor a partir do confronto, da ressignificação dos saberes presentes nessas práticas que ministra no ambiente que desenvolve sua docência.

Tardif (2002) ressalta que levando em consideração o papel formativo das práticas pedagógicas, devemos valorizar a constante tradução dos saberes docentes em função da prática exercida dentro do ambiente escolar. Segundo Tardif (2002)

Os saberes docentes são oriundos de fontes sociais diversas (família, escola, universidade), adquiridos em tempos sociais diferentes (tempo de infância, da escola, da formação profissional, do ingresso na profissão, da carreira), mas também são pragmáticos, pois estão diretamente ligados tanto ao trabalho, quanto à experiência profissional e à pessoa do professor (TARDIF, 2002, p. 104,105).

Mais uma vez, constatamos que as formações de professores são de fundamental importância para sua prática como fortaleceu a citação acima de Tardif, pois, professor que não participa de constantes formações ficam alheios as reformulações do sistema educacional em prol da qualidade de ensino.

A definição de professor e a prática utilizada é definida por muitos autores de maneira divergente uma das outras, mas, as ideias desses autores mostram semelhanças quando dizem que cada docente constrói sua identidade quando transmitem conhecimentos aos discentes a partir das formações recebidas.

Um desses autores, Bernadete A. Gatti (2003) define o professor como ser que transmite cotidianamente seu conhecimento através das metodologias aplicadas em sala de aula exercendo um papel de formação social dos discentes conhecedores de seus direitos e deveres. Segundo a autora:

É preciso ver os professores não como seres abstratos, ou essencialmente intelectuais, mas, como seres essencialmente sociais, com suas identidades pessoais e profissionais, imersos numa vida grupal na qual partilham uma cultura, derivando seus conhecimentos, 
valores e atitudes dessas relações, com base nas representações constituídas nesse processo que é ao mesmo tempo, social e intersubjetivo (GATTI, 2003, p. 196).

A visão de ${ }^{14}$ Gatti é muito parecida com a de Saviani, professores devem exercer função social dentro da escola que é o ambiente ideal para formação de cidadãos conscientes de direitos e prática de seus deveres.

Compreendemos que o professor na prática de sua profissão forma sua identidade individual e coletiva abordando os conhecimentos adquiridos durante sua formação docente, ou seja, se relaciona os saberes adquiridos na trajetória de vida, na vivência particular, saberes advindos de suas práticas pedagógicas cotidianamente junto aos seus discentes.

Portanto, a formação de professores vem dos saberes provenientes de uma interação entre sujeitos e a produção histórica social a ser aplicada aos educandos na prática docente do profissional que atua na sala de aula.

Quando falamos de formação de professores nos deportamos para o município sujeito da pesquisa com o quadro de profissional da educação atuando em Aquiraz tentando superar as dificuldades que aparecem em sala de aula constantemente, mas, respaldados em estudos e muita leitura dos conhecidos teóricos já citados no decorrer de nossa dissertação. Pimenta (1999) considera que a construção da identidade docente está vinculada aos saberes da docência, para a autora são constituídos conforme o quadro abaixo:

Quadro 18: Saberes Docentes segundo Pimenta (1999)

a) pelos saberes da experiência (influência dos vários professores ao longo da vida escolar dos docentes; experiência socialmente acumulada; socialização no cotidiano docente); 
b) pelo conhecimento adquirido nas instituições formadoras (educação como processo de humanização pela aquisição do conhecimento, por professores e alunos, numa perspectiva de inserção social crítica e transformadora);

c) pelos saberes pedagógicos (constituídos da intima vinculação entre formação teórica e prática docente).

Fonte: ARAUJO, M. V. de. Baseado nos estudos de Pimenta (1999)

No quadro Pimenta ressaltou experiência, conhecimento e saberes pedagógicos fatores primordiais para um bom saber docente para professores.

\section{FASES DO PERCURSO FORMATIVO DOCENTE}

Das referencias utilizadas para fundamentação desse trabalho, constatamos que a profissão docente no Brasil passou por vários períodos históricos se configurando como um processo de formação permanente e de desenvolvimento pessoal e profissional do professor compreendendo não apenas os conhecimentos $e$ competências, mas também a formação de sua identidade no cotidiano exercício de docência.

Notoriamente percebemos a necessidade de compatibilizar o desenvolvimento do professor com o desenvolvimento organizacional da escola, um dos autores pesquisados sobre percurso formativo docente e o processo de formação do professor foi Day (1999), esse autor traçou seis princípios para atender o processo de formação do professor que são os colocados no quadro a seguir:

Quadro 19: Processo de Formação do Professor segundo Day (1999)

I - O desenvolvimento do docente é contínuo, se realizando ao longo de toda vida;

II - Deve ser autogerido, sendo, contudo, da responsabilidade conjunta do professor e da escola 
III - Deve ser apoiado e dispor dos recursos materiais e humanos necessários à sua concretização

IV - Deve responder aos interesses do professor e da escola, embora nem sempre em simultâneo

V - Deve se configurar como um processo credível

$\mathrm{VI}$ - Deve ser diferenciado, de acordo com as necessidades dos professores, designadamente as especificas de sua etapa de desenvolvimento profissional

Fonte: ARAÚJO, M. V. de. Baseado nos dados dos estudos de Day (1999)

Por estarmos desenvolvendo uma pesquisa qualitativa e documental, utilizamos aplicação de questionários a colegas docentes e ao analisarmos seus relatos de vida profissional, compreendemos que a formação para ser um professor é um processo que se inicia muito antes de entrar na profissão de docente.

A prática docente e a didática a se aplicar se revelam das influências das experiências escolares, das relações familiares, profissionais e sociais vivenciadas em momentos diferentes do percurso de sua vida até a decisão de ser professor.

Ao pesquisarmos sobre a formação docente, encontramos informações de que ela recebe uma significativa contribuição da teoria da complexidade proposta por Morin (2002) com os fenômenos avaliados em seu processo, por diferentes e não apenas pelo fato isolado de querer ser professor. $\mathrm{O}$ autor propõe um paralelo com a formação docente, que não pode ser um produto final de um centro acadêmico.

Podemos assim, ressaltar que a formação de professores concebe o processo como uma produção que passa por diversas ordens dos conhecimentos e das experiências vivenciadas cotidianamente. Sobre esse pensamento, Pacheco e Flores (1999) apontam quatro fases que influenciam a ação docente, vejamos essas fases no quadro abaixo: 
Quadro 20: Fases que Influenciam a Ação Docente

1) A fase de Pré-treino, experiências enquanto alunos escolares;

2) A formação inicial, período que além de outras aprendizagens, também proporciona as primeiras atuações como professor;

3) A iniciação, que corresponde aos primeiros anos de exercício de seu ofício; 4) A formação permanente que se encontram os professores experientes.

Fonte: ARAÚJO, M. V. de. Baseado nos estudos Pacheco e Flores (1999)

Cada fase explicitamente fomenta uma real importância no percurso formativo do docente, o período do Pré-treino é o mais demorado que o sujeito passa para construir sua referência de ser um professor, mas, com certeza, esse período é bastante significativo, pois, é nele que se concebe a primeira impressão sobre a docência.

Podemos dizer que essa fase é um dos pontos que poderá motivar a escolha do sujeito para exercer a função de professor, pois, seus olhares estão voltados para os vários exemplos que observaram durante sua vivência, avaliando-os para uma análise do seguimento que realmente o auxiliar no emprego de sua docência.

Quando inicia sua docência, o professor se depara com diversidades em sala de aula, mas, essas contribuem para ampliação que ele (professor) atue em campos por desconhecidos não repassados em sua formação, assim, se ver lidando com a saúde quando aplica atividades físicas que levam ao fortalecimento muscular, além de atuar no campo esportivo quando aplica dinâmicas recreativas e a atuação mais importante no campo da educação escolar quando transmite conhecimento sistematizado aos educandos.

Esse pensamento está fundamentado na citação de Borges e Derbiens (2005) quando ressaltam que: "[...] colocam em evidenciar a orientação plural, ao mesmo tempo individual e social, que de certa forma orienta a escolha e as experiências préprofissionais [...] (BORGES e DERBIENS, 2005, p. 171). Esses fatores fazem parte da fase de Pré-treino, retrataremos a seguir a relação na próxima fase. 
Temos como segunda fase a formação inicial ou estágio que ocupa um lugar de suma importância na identidade profissional, pois, nesse momento o sujeito se aproxima dos princípios educativos de como ensinar, ou seja, com o propósito de ensinar algo a alguém e o preparar para vida. Respaldamos esse pensamento na citação de Cesário (2008) que diz:

[...] entendemos que a formação inicial ocupa um lugar importante, mas, não exclusivo no processo de desenvolvimento profissional do professor, uma vez que fornece ao futuro profissional as bases para a construção de conhecimentos pedagógicos. Além disso, a formação inicial compõe o começo de sua socialização profissional e a assunção de princípios e regras práticas necessárias à sua ação pedagógica (CESARÁRIO, 2008, p. 62).

Nessa fase podemos identificar algumas potencialidades que são construídas de acordo com a prática educativa que o professor assume, segundo Mizukami (2002) essas são identificadas como:

"[...] responsáveis por gerar marcos de referência, esquemas cognitivos capazes de instruir, orientar, clarificar, favorecer, esquemas cognitivos capazes de instruir, orientar, clarificar, favorecer o melhor entendimento da prática docente". (MIZUKAMI; REALI, 2002, p.228).

Devemos ressaltar que a fase formativa inicial do professor segundo Ribeiro (1999) traz momentos de desenvolvimento de competências e pode ser retratada como formação permanente ou aprendizagem permanente dos professores, o autor diz que:

A ideia de formação permanente ou aprendizagem permanente dos professores traz em si a formação inicial e continuada como dois momentos de um mesmo processo de desenvolvimento de competências profissionais (RIBEIRO apud PACHECO \& FLORES, 1999, p. 127). 
Consideramos dessa maneira que o professor ao dá início a seu estágio curricular, começa com ele sua primeira socialização devido à aproximação com o campo em que irá desenvolver sua didática pedagógica, seu ensino aos educandos. Esse pensamento vem reforçado no que diz Marcelo (1998) que ressalta essencialmente o contínuo processo de desenvolvimento do professor. Ele diz que:

A formação inicial deve ser entendida sob a perspectiva de indicar e propor dispositivos com esse propósito, da mesma forma em que a iniciação ao ensino (professores nos primeiros anos de ensino) deve ser entendida como parte integrante do contínuo processo de desenvolvimento profissional (MARCELO, 1998, p.34).

Consequentemente entendemos que o processo de desenvolvimento formativo do professor se torna essencial em sua prática pedagógica como estudiosos da área de formação de professores tão bem ressaltaram e foram colocados nesse trabalho investigativo, um desses autores, Pimenta (2005) diz que o certificado de professor exerce um grau de importância, segundo o autor:

Este processo é essencial para a Formação Inicial, o estágio e as disciplinas que compõem o currículo de curso, são obrigatórias para se obter o certificado de conclusão, ou seja, são vinculados em mesmo grau de importância (PIMENTA, 2005, p 156)

Reforçando o pensamento de Pimenta, para falar da fase de formação inicial, constatamos que três elementos estão envolvidos nessa etapa: o estagiário, os formadores e o contexto escolar que deve favorecer amplamente a construção do conhecimento em conjunto interligado, no intuito de melhorar a qualidade do ensino e repercutir na valorização da educação e do profissional que nela se envolve no processo de ensino e aprendizagem no Brasil.

Outro autor que define a fase inicial como base para a profissionalização do professor é Silva (2004), essa autora retrata esse período como determinante na concepção do docente em relação ao desempenho de suas funções. Segundo a autora: "[...] o 
professor deve ter uma sólida formação de base e estar disponível para uma formação contínua e continuada, desligada de uma lógica de oferta e procura individual" (SILVA, 2004, p. 110).

Vemos no pensamento da autora que o professor não deva se contentar apenas com sua graduação, seu certificado, pois, ela serve apenas de base para sua profissionalização como docente, ele deve estar disponível para uma constante e atualizada formação, assim estará apto a exercer qualificadamente sua função de professor.

Acreditamos assim que, no período da formação inicial, o professor configura sua identidade profissional e a consolida, traçando, portanto, suas expectativas e perspectivas educacionais construídas ao longo do curso de formação docente. Claro que essa fase de construção do conhecimento possibilita ao docente exercer as primeiras operações concretas na escola e enfatizar sua aprendizagem.

Para descrever a terceira fase denominada de iniciação, devemos dizer que ela corresponde aos primeiros anos de exercício docente e que se diferencia significativamente da etapa em que estava estagiando, isso porque, nesse momento deixa de ter o apoio dos orientadores, e passa a interagir com o contexto escolar, o currículo e tem a liberdade de agir de acordo com a sua aprendizagem e organização.

Para Tardif (2008), essa fase para o professor se constitui nos primeiros anos de sua carreira docente, sendo necessário uma adaptação rápida do meio estudantil que irá atuar. Esse autor ressalta que:

[...] assegura a prática da profissão o conhecimento destes objetoscondições insere-se necessariamente num processo de aprendizagem rápida: é no início da carreira (de 1 a 5 anos) que os professores acumulam, ao que parece, sua experiência fundamental (TARDIF, 2008, p.51).

A citação de Tardif mostra que a experiência vivenciada cotidianamente pelo docente é fundamental e transformadora para a maneira pessoal em que irá lecionar, porem 
se faz necessário emergencialmente que sua adaptação com a realidade de seu trabalho ocorra de maneira gradual a sua atuação, pois, docência não pode ser alinhavada, tão pouco acabada com as experiências de seus primeiros aos de atuação e sim continuadamente devem ser renovados seus conhecimentos.

Vemos ainda que a formação inicial de professores se corresponde com a extensão e a profundidade perante os princípios que orientam a reforma da educação básica e as diretrizes traçadas para a docência junto aos educandos quando inicia sua profissionalização.

Portanto, constatamos que a formação inicial possibilita ao professor, a construção de conhecimentos que norteiam suas ações pedagógicas, através dela, é fornecido subsídios de saber argumentar, escolher e desenvolver sua didática de ensino de maneira autônoma.

É pertinente ainda saber que é preciso aproximaras instruções de maneira que venham favorecer aos futuros professores competências docentes necessárias para que ele ensine e os alunos aprendam de acordo com os objetivos e diretrizes pedagógicas traçadas para o desenvolvimento qualificado dos educandos da educação básica.

\section{FORMAÇÃO PERMANENTE/CONTINUADA}

Chegamos a fase que conclui esse capítulo sobre formação docente no Brasil, onde a escola se adéqua as constantes reformas educativas que são desencadeadas pela transformação da sociedade ocorridas pelas inovações tecnológicas e cientificas, de maneira que levam a alterações das relações sociais, levando os docentes a sentirem necessidades de procurarem outros modos de formação que atenda a clientela assistida por ele.

Nesse contexto, percebemos que realmente se faz necessária a formação continuada por parte do professor, uma vez que eles precisam estar atualizados e em contato 
com as modificações sugeridas para o sistema educacional nos diferentes períodos históricos da educação brasileira.

Ao propormos uma investigação sobre formação de professores, queríamos no fundo, nos renovar diante de nossas práticas didáticas, que estivessem fundamentadas nas alterações educacionais que afetam nossa sociedade em diferentes aspectos como: políticos, culturais, sociais e econômicos.

Os fatos mencionados acarretam alterações das ${ }^{15}$ concepções e na ação docente, levando o professor a procurar diferentes cursos de capacitação profissional/formação continuada, devendo ser investigado as finalidades e objetivos inclusos nessas para melhoria de sua docência.

Sabemos que grande parte das propostas educativas são advindas do pressuposto de que o professor é o único responsável, tanto pela busca de sua capacitação como pelo resultado satisfatório do sistema educacional. Segundo Almeida (1999), vários fatores impedem que a educação seja repassada de maneira verdadeiramente qualificada, diz ainda que:

[...] desqualificação do trabalho do professor e sua desvalorização profissional. A ele são impostas condições de trabalhos deficientes e salários irrisórios, obrigando-o a uma atuação sem significado (ALMEIDA, 1999, p. 255).

Substancialmente a formação continuada não pode ser planejada e ministrada somente com intuito de preencher lacunas do conhecimento que o professor tenha necessidade, ou simplesmente treinar esse profissional para aplicar um programa novo de ensino.

Entendemos que as duas formas mencionadas: conhecimento e treinamento apenas reduzem às estratégias, aos meios para ensinar, não proporcionam reflexões sobre conceitos, nem são consideradas as próprias ações do professor. Entendemos que a formação continuada de um docente deve ser vigorada de acordo com os fatores legalizados nas leis educacionais, e, acima de tudo, em um entendimento da 
conjuntura educacional. A Lei de Diretrizes e Bases da Educação Nacional, LDBEN 9394/96, afirma que:

A formação continuada é direito de todos os profissionais da educação, que trabalham em qualquer estabelecimento de ensino, uma vez que contribui para a progressão funcional baseada na titulação, e na qualificação dos saberes do professor, que resulta igualmente na melhoria das aprendizagens de seus alunos (BRASIL, LDBEN, 96).

Para entendimento da Lei, devemos compreender o significado do termo: formação continuada, em nosso entender, ele está atrelado à ideia de continuidade da necessidade constante de reflexão na formação para o exercício profissional como docente.

Mas, como o próprio nome diz, o docente precisa de uma constante formação, ao concluir a inicial, os professores são pressionados pelo contexto social a continuarem seus estudos com a finalidade de galgar pontos em seus currículos pessoais e assim, conseguir um espaço no mercado de trabalho. Para Larossa (2004), a educação é:

A educação é práxis reflexiva, a experiência se envolve nessa ação de pensar sobre a própria ação com os conhecimentos construídos anteriormente, por essa razão ao falarmos da formação docente estamos nos concentrando em conhecimentos inerentes também a atuação em sala de aula (LAROSSA, 2004, p. 151).

Vemos na citação de Larossa que o docente ao entrar na sala de aula precisa estar consciente de sua prática, saber a que tipo de sujeito está sendo formado, o conhecimento que adquiri na formação recebida no curso de realizado.

$\mathrm{Na}$ formação de professores o principal elemento a ser estudado, não pode ser as regras, as estratégias, mas sim, os conceitos, as teorias que orientam essas ações, pois, ao reconhecer e identificar sua ação docente dentro de uma perspectiva que venha promover uma educação de sujeitos reflexivos. 
Toda formação continuada é baseada na concepção do docente ter uma ação e reflexão crítica, em que, o professor possa relacionar os conhecimentos de sua trajetória acadêmica e os construídos na sua prática cotidiana de sala de aula. Segundo Tardif (2008) há uma perspectiva importante para uma significativa formação continuada, ele diz que:

[...] a partir deles que os professores julgam sua formação anterior ou sua formação ao longo da carreira. É igualmente a partir deles que julgam a pertinência ou o realismo das reformas introduzidas nos programas ou nos métodos. Enfim, é ainda a partir dos saberes experienciais que os professores concebem os modelos de excelência profissional dentro de sua profissão (TARDIF, 2008, p. 48).

Tardif (2008) ressalta que a prática do docente deve ser organizada a partir de sua vivência atrelada aos aspectos afetivos, normativos e existenciais. Segundo Tardif (2008):

Ele aborda sua prática e a organiza a partir de sua vivência, de sua história de vida, de sua afetividade e de seus valores. Seus saberes estão enraizados em sua história de vida e em sua experiência do ofício de ser professor. Portanto, eles não são somente representações cognitivas, mas possuem também dimensões efetivas, normativas e existenciais. Eles agem como crenças e certezas pessoais a partir das quais o professor filtra e organiza sua prática. (TARDIF, 2008, p.233)

Por tudo descrito sobre a formação continuada de professores, refletimos que a origem dos conhecimentos, e do saber docente se faz necessário uma contemplação sobre a complexidade envolvendo os diferentes momentos da formação.

Percebemos que cada fase, ou etapa, transmite influência para que o sujeito se transforme, se modifique pela sua reflexão da ação docente. O conhecimento é transmitido e construído pelo processo de ensino e aprendizagem, no instante que em meio a situação de reflexão do docente que analisa criticamente a sua atuação, 
porque esse docente não é mais um conhecimento que recebeu na formação acadêmica, ele é a implementação de todos os conhecimentos na prática docente.

\section{CAPÍTULO}

\section{CURRÍCULO: CONSTRUÇÃO, IMPLEMENTAÇÃO E AVALIAÇÃO}

Para falar de currículo é constatar como é estruturada a organização curricular da Educação Básica. Devemos considerar que o currículo escolar é uma necessidade permanente hoje e sempre, não apenas em um momento determinado frente a uma questão pontual.

Devemos ter conhecimento das teorias curriculares que tiveram e tem maior expressão nas escolas brasileiras. Salientamos que a ação docente necessita constatar de como acontece o desenvolvimento das escolas a partir das teorias curriculares que podem ser evidenciadas por meio das análises dos modelos ou estruturas curriculares, que apresentam de forma concreta as respectivas epistemologias regentes, na qual, enfatizam suas diferenças e finalidades.

As leituras nos deram um conhecimento de que a maioria das escolas nacionais são compostas de currículos disciplinares, assim como também, a formação dos professores, além do currículo, abordaremos a avaliação desse, e a formação continuada, quais as contribuições dessa reflexão, o que, para que, como, porque se avaliar educandos dentro do sistema educacional.

Objetivamente precisamos de uma organização curricular que seja capaz de atender aos anseios e necessidades de formação de nossos educandos, sejam eles, crianças ou jovens, e, Ihes assegurar a qualidade de ensino dentro do sistema educacional.

$\mathrm{Na}$ contemporaneidade quando falamos em qualidade de ensino, precisamos levar em conta que se trata de uma concepção mutável, de acordo com o período em vivência. Entendemos que debater currículo e qualidade do ensino, significa pensar e repensar o conceito de qualidade na atual época que vivemos e acima de tudo, dos pilares de uma organização curricular entrelaçada com este conceito. 
Entendemos ainda que, a leitura e a escrita continuam sendo a base do currículo, o alicerce do processo educativo, pois, sem leitura e a escrita os educandos não conseguem sequer acompanhar as demais disciplinas. As disciplinas mencionadas devem ser pensadas em sua unilateralidade.

\section{TEORIA E DESENVOLVIMENTO CURRICULAR}

Nossas leituras nos levaram a descobertas da existência de diversas teorias que se encontram ligadas aos contextos históricos e as teorias educacionais, constatamos assim que, o percurso dos estudos sobre currículo, quais são seus objetivos, como forram constituídos na escola estão amplamente ligados ao tema em pesquisa.

Segundo Mccutcheon (1982) o papel da teoria curricular tem a necessidade de estar fundamentada nas decisões epistemológicas, para ele:

[...] as decisões epistemológicas correspondem a um conjunto organizado de análises, interpretações e compreensões dos fenômenos curriculares em que descreve e compreende os conhecimentos curriculares, de modo a oferecer subsídios para suas melhorias (MCCUTCHEON, 1982, p. 18).

Vemos assim na citação do autor a correspondência da epistemologia com conhecimentos adquiridos a ser repassados aos discentes dentro das interpretações e compreensões dos currículos aplicados nas instituições de ensino.

Outra percepção que temos é que a proposta original do currículo escolar para idealizar conteúdos e fazer prescrição, esse conteúdo vem com o propósito de conduzir o percurso dos ensinamentos do docente quando esse evidencia sua analise a sua etimologia, essa se define segundo Goodson (2008): "[...] palavra latina Scurrere, correr, e refere-se a curso" (GOODSON, 2008, p. 31).

Analisando a visão de Goodson, vemos que o contexto e a construção social não são relevantes, de forma que a "definição da realidade" é posta firmemente por técnicos 
que esboçavam e definiam a sua operacionalização, dada de forma pronta e acabada aos professores em sua formação pedagógica.

Salientamos assim que, antes do currículo existir, havia meios de sistematizar o conhecimento, esse tinha a finalidade de levar os alunos a ler, escrever, ${ }^{16}$ operacionalizar as quatro operações matemáticas e que conseguissem sua formação disciplinada de acordo com os interesses sociais e políticos com base estruturante dos conteúdos aplicados.

Não podemos deixar de destacar que a disciplina segundo o dicionário se trata de obediência ao conjunto de regras e normas que são estabelecidos por determinado grupo. Também pode se referir ao cumprimento de responsabilidades específicas de cada pessoa. Mas para Chervel (1990), disciplina seria:

A análise do termo disciplina evidência essa colocação, assim, "no seu uso escolar, o termo "disciplina" e a expressão "disciplina escolar" não designam, até o fim do século XIX mais do que a vigilância dos estabelecimentos, a repressão das condutas prejudiciais à sua boa ordem (CHERVEL, 1990, p. 178).

Vemos na afirmação de Chervel que a palavra disciplina denota uma intenção diferente da que podemos dizer atualmente que configura como sinônimo de matéria, ela tinha como propósito formar sujeitos civilizados a servir a sociedade.

Mas, se pensarmos na concepção de Paulo Freire dentro do processo de leitura e escrita relacionada a disciplina onde o sujeito aprende dando sentido às palavras, que deve ser uma ferramenta para ler o mundo, para (re)interpretar a realidade, e inserirse nela, ou seja, para Paulo Freire o currículo e a disciplina devem estar dentro do contexto de vivencia do sujeito para que assim se desenvolva plenamente.

Devemos também ver os estudos da história da origem do currículo, com ela, se amplia o interesse e o campo de investigação das ciências, já que, qualquer análise sobre o campo curricular está interligada ao desenvolvimento da educação. Segundo Pacheco (2006): 
O campo curricular situa-se, em primeiro lugar, nas Ciências da Educação, por meio das Ciências Sociais, e só depois no objeto e metodologia que caracterizam como espaço autônomo (PACHECO, 2006, p. 248).

O pensamento de Pacheco, mostra que toda e qualquer pesquisa se realizam, a fim de, contrair o modelo de currículo prescritivo, em que a transmissão dos conteúdos fica enfatizada, sem questionamento de sua origem ou ideologia contida nos cursos de formação docente.

Quando procuramos definições da organização escolar e currículo, encontramos na pesquisa de Goodson (2008) o seguinte:

Assim, os conflitos em torno da definição do currículo escrito proporcionam uma prova visível, pública e autêntica da luta constante que envolve as aspirações e objetivos de escolarização (GOODSON, 2008, p. 17).

Assim vemos, na citação de Goodson que o resultado de uma investigação sobre escolarização esbarra em algumas dificuldades, começando pelo conceito do currículo e consequentemente na sua elaboração e implementação dentro das instituições educacionais, pois, ele deve estar elaborado de acordo com os anseios e objetivos a serem alcançados.

Para reforçar o pensamento de Goodson que mencionou dificuldades para elaboração e implementação do currículo, buscamos nos estudos de Pacheco três áreas de dificuldades por ele colocadas em seus estudos de (2006), onde menciona a história do currículo escolar, no momento da elaboração e desenvolvimento do planejamento. Para Pacheco (2006) as áreas de dificuldades do currículo seriam:

Quadro 21: Dificuldades da Elaboração e Implementação do Currículo segundo Pacheco 
Primeira dificuldade reside na terminologia: Didática, Didática Geral, Didática Específica, Currículo, Desenvolvimento Curricular, Organização e Desenvolvimento Curricular, Teoria Curricular, Teoria e Desenvolvimento Curricular (PACHECO, 2005, p. 07)

Segunda dificuldade se relaciona com a edificação de um campo epistemológico específico, cuja emergência e consolidação se verifica no contexto da Formação de Professores (PACHECO, 2005, p. 07).

Terceira dificuldade se refere ao percurso histórico, diz respeito às escolas de pensamento e as distintas teorias que influenciaram o currículo brasileiro nas décadas de 1920 e 1930 quando ocorreram em nosso país importantes transformações políticas, econômicas e culturais (PACHECO, 2005 p. 08).

Fonte: ARAÚJO, M. V. de. Baseado nos estudos de Pacheco (2005)

Vimos na primeira dificuldade mencionada nos estudos de Pacheco uma infinidade de denominações, mas, nas pesquisas utilizadas em nosso estudo, elas mostraram que existem ainda alguns complementos como: Grade Curricular, Programas Escolares, Projeto Político Pedagógico. De todos mencionados, atualmente, os mais usados são: Currículo e Projeto Político Pedagógico. Pacheco ressalta ainda em seus estudos que:

A segunda dificuldade está relacionada com a edificação de um campo epistemológico específico, cuja emergência e consolidação verificam no contexto da formação de professores (PACHECO, 2005, 07).

Portanto, percebemos na citação do autor que, na constituição de departamentos direcionados aos estudos sobre currículos, a serem entendidos como ferramentas de trabalho indispensáveis para docentes e pedagogos, e na ressignificação dos seus próprios currículos, pois estão diretamente ligados ao desenvolvimento de seu trabalho pedagógico.

Quanto a terceira dificuldade, Pacheco ressalta ainda que: "A influência norteamericana era forte, principalmente de autores associados ao pragmatismo. Havia também influência europeia associada à Escola Nova". (PACHECO, 2005, p. 08) 
Para o autor mencionado, o currículo norteado pela perspectiva do pragmatismo, delegava a função da elaboração aos especialistas, esses deveriam criar currículos específicos a cada habilidade, além de incluir a criação das avaliações, para que assim, fosse realmente moldada a aprendizagem e o desenvolvimento curricular era considerado como uma mecânica, com padrões a serem seguidos, não se levava em conta a clientela recebida, e sim, o currículo a ser seguido.

Mas, depois dos estudos baseados no pragmatismo, veio a inserção dos estudos realizados pelas outras áreas das ciências humanas, com elas, foi possível averiguar todas as dificuldades encontradas ao se planejar o currículo percebendo a necessidade à constituição de uma teoria crítica de currículo, segundo Pacheco (2005) são advindas das:

[...] orientações teóricas que tem sua origem em Kant, Hegel, e Marx, a sua sistematização em Horkheimer, por causa da sua relevância, atualmente tornou-se presente nas diversas áreas do conhecimento (PACHECO, 2005, p. 91).

Para Pacheco (2005) a teoria de currículo crítica se configura na capacidade de olhar para as possibilidades de transformação da prática, para ele, baseado em dois princípios estruturantes:

Quadro 22: Princípios Estruturantes do Currículo segundo Pacheco

Primeiro: a orientação para emancipação e pensamento crítico, que está imersa as investigações no campo de disputa de poder.

Segundo: concretização de uma identidade, que diante de tantas culturas e concepções teóricas se expande a outros setores que não seja tão escolar, como aos centros de formação de professores.

Fonte: ARAÚJO, M. V. de. Baseado nos estudos de Pacheco (2005)

Percebemos nos princípios do autor que devem ocorrer discussões desses, na formação do professor, seja ela, inicial ou continuada, sobre questões enredadas na 
complexidade da teoria e da abstração do currículo. Por isso, as funções que o currículo cumpre como expressões do projeto político cultural e da socialização, são realizadas por meio de seus conteúdos, de seu formato e das práticas que gera em torno de si.

\section{ORGANIZAÇÃO CURRICULAR NO BRASIL E OS MODELOS CURRICULARES}

É pertinente o currículo para educação e que ele vem sendo formado e definido no decorrer dos tempos, as primeiras preocupações com o currículo no Brasil vêm desde os anos 20, e até a década de 1980, nosso currículo foi marcado pela transferência instrumental das teorizações americanas. Segundo Lopes; Macedo (2002):

Essa transferência centrava na assimilação de modelos para a elaboração curricular, em sua maioria de viés funcionalista, e era viabilizada por acordos bilaterais entre o governo brasileiro e norte-americano do programa de ajuda à "América" (LOPES; MACEDO, 2002, p. 13).

A citação mostra que um currículo baseado em modelos de outros para ser aplicado em nosso território, seria necessário um planejamento, no Brasil a legalidade interna dele ocorreu num período de oito anos para ser constituído.

Sabemos que Documentos Oficiais relacionados a educação como PCNs e RCNEI, embora não se constituam como obrigatórios, foram elaborados pelo governo brasileiro, representado pelo MEC, em 1988 com a finalidade de apresentar à comunidade escolar o cumprimento do Art. 210 da Constituição Federal, esse Art. determina que é dever do Estado para com a educação fixar:

[...] conteúdo mínimos para o Ensino Fundamental, de maneira a assegurar a formação básica comum e respeito aos valores culturais e artísticos, nacionais e regionais (BRASIL, 2007, p.05. E). 
Na construção do PPP, de acordo com a LDB 9394/96 dentro das orientações dos PCNs que determinam irrevogavelmente a composição de uma base nacional comum na educação básica que:

§ 10 Integram a base nacional comum: a) Língua Portuguesa; b) Matemática; c) conhecimento do mundo físico, natural, da realidade social e política, especialmente do Brasil, incluindo-se o estudo da História e das Culturas Afro-Brasileira e Indígena; d) a Arte, em suas diferentes formas de expressão, incluindo-se a música; e) a Educação Física; f) o Ensino Religioso (BRASIL, 2010, p. 66 b, grifo nosso).

Outro ponto que devemos levantar é o de que, planejamento escolar deve ser autônomo para todos os membros com ele envolvido nos aspectos como: a escolha do modelo e o motivo de sua escolha, a viabilidade e críticas existentes, esses aspectos vêm possibilitado na LDBEN 9394/96 que registra em seu Art. $2^{\circ}$ sobre o Projeto Político Pedagógico que:

$\S 2^{\circ}$ Cabe à escola, considerada a sua identidade e a de seus sujeitos, articular a formulação do Projeto Político Pedagógico com os planos de educação - nacional, estadual, municipal -, o contexto em que a escola se situa e as necessidades locais e de seus estudantes, (BRASIL, 2010, p. 73 b).

O Artigo mostra que o PPP deve levar em conta o contexto da escola e as necessidades apresentadas pelos alunos e acima de tudo, sua elaboração tenha autonomia de escolha, assim a estrutura curricular deve ter um significado instituído na organização curricular existindo uma predominância do equilíbrio entre sociedade, o educando e o saber estruturado levando em conta os seguintes elementos:

- a) cultura; b) contexto social; c) visão de mundo; d) políticas públicas; e) teorias educacionais; f) concepção do processo de ensino-aprendizagem; g) objetivosfinalidades, conteúdo específico; h) experiências de aprendizagens; i) estratégias e meios de ensino; j) avaliação. 
Legalmente o currículo deve levar em consideração os elementos mencionados, razão que leva a modelos recorrentes, com objetivos de analisar e verificar suas críticas e superar as dificuldades encontradas no processo de ensino-aprendizagem. Segundo Ribeiro (1998) os modelos de currículos são:

Quadro 23: Modelos de Currículo segundo Ribeiro

a) O modelo baseado em disciplinas: é dominante nas escolas brasileiras, se caracteriza segundo Ribeiro (1998) a autores que apontam ser o modelo mais lógico e eficaz; cabem aos especialistas disciplinares o estabelecimento de tal estrutura, e a participação e determinação do método.

b) O modelo baseado em núcleos de problemas/transdisciplinares: Essa perspectiva representa uma ruptura com o modelo curricular por disciplina, que correlaciona e fundi as áreas disciplinares, aproximando aos problemas atuais, do ponto de vista sociocultural entre outros, a passagem para esse modo se deu pelos estudos interdisciplinares, preocuparam-se com o elo entre as várias áreas do saber, e utiliza como técnica além do trabalho individual os trabalhos em grupo, para isso precisa-se de um professor com saberes amplos, por essa razão defende uma formação mais geral

c) Modelo baseado em situações e funções sociais: tenta aproximar os conhecimentos das causas sociais, quotidianas em que os alunos se defrontam ou vem a defrontar, para isso promove a instrumentalização por meio dos estudos das matérias com resolução dos problemas que envolvem as atividades sócias comunitárias.

d) Modelo centrado no educando: Apresentam modalidades diversas, currículo baseado em atividade e na experiência da criança, movimento criado pela escola e classes abertas, em que o currículo deve estar estabelecido em função direta aos interesses dos educandos.

e) outros modelos de organização curricular: que em rigor representa mais princípios metodológicos de construção de planos de ensino, divididos em dois exemplos, o primeiro baseia-se em processos cognitivos colocados por áreas de 86 saberes, reside em produzir o máximo potencial de transferência 
de aprendizagem e na consolidação da aprendizagem permanente. $O$ segundo modelo estrutura-se em torno das funções e competências determinadas, no estabelecimento de perfil funcional, e sua capacidade de resolução por meio da sequência lógica do conhecimento, com objetivos comportamentalistas em virtude do desempenho e característica do modelo behaviorista.

Fonte: ARAUJO, M. V. de. Baseado nos estudos de Ribeiro (1998)

Os vários modelos estruturados por Ribeiro (1998) nos levam a pensar em um modelo curricular adequado com condições de execução da pratica pedagógica relacionado a realidade dos educandos com requisitos em um conjunto de caminhos para se repensar a formação dos professores, na composição do grupo de ensino, pelo pensamento de Ribeiro, talvez seja este o real motivo que muitos currículos não chegarem ainda a ter condições de serem implantados.

Analisando os modelos acima colocados, podemos compreender a organização dos currículos das escolas públicas brasileiras, e, da maioria das escolas particulares, essas possuem uma organização por meio de disciplinas ou matérias, colocadas de forma progressiva nas seriações, com disciplinas especificas de cada área de conhecimento.

A compreensão da organização curricular é de suma importância para nosso objeto de pesquisa, pois assim, podemos entender como ocorre muitos currículos de formação de professores que ainda estão estruturados pela racionalidade/técnica, restrita em áreas de conhecimento. Mas, segundo Pimenta, os estudos ministrados nas formações de professores são de modelo formativo, ele diz que:

[...] a formação dos profissionais não mais se dê nos moldes de um currículo normativo que primeiro apresenta ciência, depois sua aplicação [...]", com a separação entre os conhecimentos acadêmicos e a realidade, desta forma, negam a formação de professores constituída no modelo tradicional, em que ainda se mantêm uma cultura dividida, 
restrita a conhecimentos isolados, fragmentados (PIMENTA, 2006, p. 19).

Na citação Pimenta deixa claro a importância do currículo na formação de professores e que ele não pode nem deve ser fragmentado e acima de tudo, deverá estar relacionado com as vivencias da clientela, pois, esse modelo de currículo não favorece a uma educação integral do sujeito devendo a fragmentação do conhecimento ser superada.

Para acabar com a questão levantada sobre currículo fragmentado, a LDB 9394, de 20 de dezembro de 1996, estabelece no Art. 26 uma abertura da liberdade dada às escolas. Vejamos este Artigo:

Os currículos do ensino fundamental e médio devem ter uma base nacional comum, a ser complementada, em cada sistema de ensino e estabelecimento escolar, por uma parte diversificada, exigida pelas características regionais e locais da sociedade, da cultura, da economia e da clientela (BRASIL, LDB, 93/94/96).

Esse Art. mostra que o currículo deve estar diversificado com características regionais e locais da sociedade, da cultura, da economia e da clientela a ser atendida. Encontramos ainda nesse Documento outra citação sobre currículo, sua complexidade e rotinas, essa vem com indagações sobre suas condições concretas, sua história, seu retorno e sua organização interna.

Com a perspectiva de atender aos desafios postos pelas orientações e normas vigentes, é preciso olhar de perto a escola, seus sujeitos, suas complexidades e rotinas e fazer as indagações sobre suas condições concretas, sua história, seu retorno e sua organização interna. Torna-se fundamental, com essa discussão, permitir que todos os envolvidos se questionem e busquem novas possibilidades sobre currículo: o que é? Para que serve? A quem se destina? Como se constrói? Como se implementa? (BRASIL, 2007, p. 06.). 
A LDB na perspectiva de dar plena liberdade as escolas, articula o modelo interdisciplinar dentro da estrutura de disciplinas, assim, propõe uma menor fragmentação dos conhecimentos, e, correlaciona os problemas sociais a educação dos educandos. Porém, o Art. 17 das DCNs da educação básica apresentam inerente aos níveis fundamental e médio, e como projetos que lhes permitam lidar com o conhecimento e a experiência. Vejamos esse Artigo:

Art. 17. No Ensino Fundamental e no Ensino Médio, destinar-se-ão, pelo menos, $20 \%$ do total da carga horária anual ao conjunto de programas e projetos interdisciplinares eletivos criados pela escola, previsto no projeto pedagógico, de modo que os estudantes do Ensino Fundamental e do Médio possam escolher aquele programa ou projeto com que se identifiquem e que Ihes permitam melhor lidar com o conhecimento e a experiência (BRASIL, 2010, p. 66 b).

Esse Art. nos leva a entender que a interdisciplinaridade no currículo implica em admitir que em cada situação existam variáveis interferindo simultaneamente na aprendizagem, sendo elas vindas da própria realidade, e delegar correlações, e, contextualizações aos alunos se torne inviáveis pela complexidade da ação.

Como objeto de pesquisa está interligado as formações de professores, devemos dizer que sistema educacional para ministrar uma educação de qualidade, o currículo deve levar em conta a realidade da sociedade e sua cultura, devemos dizer também que seu sucesso depende de uma gestão democrática.

Para sucesso da educação, seu desenvolvimento necessita de ser avaliado, pensado com ação coletiva de todos os sujeitos da escola que tenham clareza quanto aos aspectos de ordem profissional e curricular e devem os professores acima de tudo conhecerem os aspectos abaixo colocados no quadro: 
Quadro 24: Aspectos de Conhecimentos dos Professores para uma Educação de Qualidade

a) conhecer os princípios e as finalidades da educação, além do reconhecimento $\mathrm{e}$ análise dos dados indicados pelo índice de Desenvolvimento da Educação Básica IDEB e/ou outros indicadores, que complementem ou substituam estes, e da mesma forma conhecer suas limitações não sendo concebida como avaliação final;

b) apresentar um projeto político pedagógico concebido e assumido coletivamente pela comunidade educacional, em que são respeitadas as múltiplas diversidades e a pluralidade cultural;

c) Apoiar a riqueza da valorização das diferenças manifestadas pelos sujeitos do processo educativo, em seus diversos segmentos, respeitados o tempo e o contexto sociocultural; d) Interpretar os "padrões de qualidade" estipulados pelo governo, e verificar quais as relevâncias em seus apontamentos (BRASIL, 2007).

Fonte: ARAÚJO, M. V. de. Baseado nas informações do CNE (2010)

Portanto, compreendemos que o currículo deve estar em ação nas instituições considerando a abertura para as mudanças necessárias, uma vez que ele se modifica conforme as reflexões e análises, onde o professor se utiliza de forma direta em suas aulas o conhecimento e as avaliações sejam exercidos.

Nossa pesquisa fundamentada nos documentos mais importantes para a educação registrou a organização curricular no Brasil e os modelos deles executados nas escolas. Discutimos e registramos o currículo estruturado pelo modelo disciplinar, devido ser esse adotado no sistema educacional do município de Aquiraz.

Nossa pesquisa nos mostrou que os currículos das escolas de Aquiraz são construídos levando em consideração os conhecimentos gerais de todos os professores, segundo informações desses profissionais, eles são também individuais e compreendem cada um possui características singulares, com conhecimentos 
específicos a serem ensinados, e se organizam de acordo com a realidade de cada grupo de estudante.

Os mesmos profissionais ao serem investigados através de questionários, mencionaram que além de levar em conta a realidade dos educandos pela sua fase de aprendizagem, cabe a eles seguir os aspectos políticos e reorganizar o que serão ministrados em suas aulas, conforme seus planejamentos pedagógicos.

Portanto, concluímos esse tópico constatando a importância da organização curricular com uma gestão democrática, sua elaboração e implantação para se ter uma educação de qualidade, e, daremos continuidade falando da avaliação curricular.

\section{AVALIAÇÃO DO CURRÍCULO E A FORMAÇÃO CONTINUADA}

Ao descrevermos sobre currículo, sua organização, elaboração e implementação, percebemos sua importância e relação com a avaliação como pertencente ao processo educativo, intrínseco a ação docente que por sua vez atribui sentido e significado em todos os procedimentos por ele realizados dentro da instituição educacional.

Para compreendermos o que seja avaliação, buscamos a teoria construtivista, construída nos estudos de Hoffman (2010), ela completa o currículo e sua ligação ao processo de avaliação. Segundo o autor:

Minhas investigações teóricas sobre avaliação configuram-se hoje duas direções (não ambivalentes). Em primeiro lugar, na análise dos princípios inerentes a uma proposta construtivista de educação (a partir da teoria psicogenética de Jean Piaget), coerente com uma pedagogia libertadora, conscientizadora das diferenças sociais e culturais (HOFFMANN, 2010, p.21).

Percebemos que a perspectiva do avaliar segundo o autor, exerce uma função dialógica e interativa promovendo seres com moral e intelectualmente críticos e ativos a serem inseridos no contexto sócio político levando em consideração seus acertos e 
seus erros para que através deles construam conhecimento com a finalidade de atuarem na realidade que vivenciam.

Levando em conta o princípio mencionado, os professores do município de Aquiraz elaboram seus objetivos e instrumentos com intuito de verificar suas atuações no ambiente escolar, vemos assim, a preocupação desses profissionais com 0 desempenho dos educandos e a importância que dão ao sistema de avaliação aplicado para comprovar o conhecimento adquirido.

Nossa pesquisa focada na formação de professores buscou referenciar os fatores que a envolve, citamos no decorrer de nossa dissertação as teorias educacionais apresentando concepções sobre o que seja a avaliação, desta maneira, elas possuem intenções políticas, econômicas e sociais, estabelecidas de acordo com os objetivos propostos pelo sistema governamental. Assim, percebemos que cada período tem sua historicidade e influência na formação docente e na elaboração e implementação do currículo escolar.

Portanto, de certo modo, a ação docente é alterada, assim como o seu modo de pensar, agir na sala de aula e seus ensinamentos devem estar de acordo com o que Ihe é orientado nos diferentes períodos de formação como educador.

Ao buscarmos significados e tipos de avaliações adotadas no sistema educacional brasileiro, encontramos a informação de que a avaliação na educação estar apresentada em três campos os quais colocaremos no quadro a seguir:

Quadro 25: Campos de Avaliação na Educação

\section{Na avaliação do sistema escolar, ou do conjunto das escolas de uma rede escolar, como meio de apuração da educação pelos municípios, estados e nação,}

2. Nas avaliações dos professores durante o processo de ensinoaprendizagem; 


\section{A outra manifestação da avaliação é da própria instituição como um todo, na qual o protagonismo é do coletivo dos profissionais que trabalham e conduzem um processo complexo de formação na escola,}

Fonte: ARAÚJO, M. V. de. Baseado nas informações do MEC (2010)

Cada avaliação colocada no quadro acima tem sua importância e está relacionada a um determinado objetivo, a primeira é a principal responsabilidade do poder público, porém é um instrumento questionado pela falta das observações qualitativas e serem provas padronizadas e quantitativas, estamos falando no caso da Prova Brasil ${ }^{17}$, entre outras que são aplicadas aos nossos educandos para verificação de sua aprendizagem.

A segunda, é utilizada para verificação da aprendizagem dos estudantes, onde o professor tem um protagonismo nas respostas por eles expressas, estas servem para analisar o desenvolvimento dos conhecimentos aplicados por eles. Já a terceira é a avaliação da própria escola como um todo, nela o protagonismo é do coletivo envolvendo os profissionais que nela trabalham e conduzem um processo complexo de formação na instituição guiados por um PPP coletivo, existindo assim, a necessidade de análise do próprio currículo.

Após descrevermos os três tipos de avaliações, constatamos que as ações devem ter o mesmo princípio norteador para aprendizagem dos educandos, dessa forma, eles não são isolados e trazem a necessidade de estarem em regime de permanente interação, respeitando os objetivos de forma que se obtenha legitimidade.

Sendo assim, elencamos a avaliação do currículo e o processo de formação continuada, foco desse capítulo como análise do currículo e ao mesmo tempo faz averiguação das próprias práticas pedagógicas do professor e sua formação docente.

Para Hoffmann (2010) a compreensão da avaliação é correspondente à teoria adotada e estruturada no currículo que está intrinsecamente atrelada ao objetivo e a finalidade almejada. Esse autor afirma que: 
A avaliação é a reflexão transformada em ação. Ação, essa, que nos impulsiona a novas reflexões. Reflexão permanente do educador sobre sua realidade, e o acompanhamento de todos os passos do educando na sua trajetória de construção do conhecimento. (HOFFMANN, 2010, p.17)

A afirmação mostra que apesar da avaliação ser correspondente à teoria adotada e estruturada ao currículo, como mencionado acima, possuem funções diferentes, mas, não tem conceitos opostos, ou seja, estão ligados aos passos do educando na trajetória da aquisição de seu conhecimento.

Por tudo que descrevemos, podemos entender que a construção e avaliação do projeto curricular escolar está em constante elaboração e é inacabada, é o que diz Pacheco e Morgado (2002) quando afirmam que:

A decisão curricular jamais está terminada, a decisão curricular não é linear, é fundamental conciliar decisões, a decisão curricular é algo dinâmico que está e, permanente movimento, pois, sendo a escola um espaço de desenvolvimento coletivo e individual, com a (re) construção de saberes, de normas, de atitudes e valores; que possui uma autonomia e compromisso social (PACHECO; MORGADO, 2002. p.15)

Compreendemos na citação dos autores que a elaboração e avaliação do currículo, depende da capacidade dos professores de construírem esse projeto levando em conta a análise do contexto educativo em que estão inseridos seus educandos e fazerem com que sejam conhecidos e aceitos pela comunidade escolar onde aplicam sua didática. Segundo os autores acima mencionados:

A partir do trabalho quotidiano na escola, o professor recolhe informações muito diversas em relação aos seus alunos e que, obrigatoriamente, formaliza em registros estruturados. Os critérios que são decididos e avaliados pelos professores, pois a avaliação não é jamais um receituário de propostas que os novos mentores de 
engenharia Tyler lana nos fazem supor (PACHECO e MORGADO, 2002. p.46 e p. 48)

Podemos salientar que a citação mostra estratégias que contribuem para a coleta de informações e tratamento de dados sociocultural da comunidade escolar onde sua análise dar subsídios para o planejamento e escolha dos objetivos que farão o ensino do educador mais significativo e que não há uma única maneira de avaliar.

Já as Diretrizes Curriculares Nacionais da Educação Básica, salienta que se deve ter uma formação continuada para que de fato o currículo seja o orientar das ações docente. Vejamos o que diz seu Art. VII:

VII - preveja a formação continuada dos gestores e professores para que estes tenham a oportunidade de se manter atualizados quanto ao campo do conhecimento que thes cabe manejar, trabalhar e quanto a adoção, a opção da metodologia didático-pedagógica mais própria as aprendizagens que devem vivenciar e estimular, incluindo aquelas pertinentes as Tecnologias de Informação e Comunicação (TIC) (BRASIL, 2010, p.45 b).

Mas, ressaltamos que esse tipo de formação continuada de construção de conhecimento não foi abordado em nosso trabalho e que não basta ser conferida na lei a segurança para que se tenha um processo permanente de qualidade, o professor deve buscar sua permanente qualificação para que assim, esteja atualizado e dê qualidade a sua didática pedagógica.

Sendo assim, pensar sobre a construção, desenvolvimento e avaliação curricular, é se envolver em diversas indagações, na abordagem dos conhecimentos adquiridos nas formações de professores, sendo ela, inicial ou continuada para que se tenha qualidade educacional dentro de um processo educativo.

Portanto, a formação continuada contempla no Projeto Político Pedagógico a abrangência dos assuntos da atualidade e pertinentes aos conhecimentos escolares, porém, não podemos negar o fato de eles devem estar estruturados no próprio 
currículo e não apenas de acordo com que o professor por si só deseja implantar em sua sala de aula, vemos assim, a importância das formações continuadas para atualização da pratica pedagógica.

Concluímos esse capítulo compreendendo que os currículos presentes nas escolas e nas suas teorias pedagógicas mostram um importante significado: eles não são conteúdos prontos a serem ensinados aos alunos, e sim uma elaboração e seleção de conhecimentos e práticas produzidas em contextos concretos, em dinâmicas sociais, políticas, culturais e pedagógicas.

\section{PROCEDIMENTOS METODOLÓGICOS DA PESQUISA}

Chegamos ao quarto capítulo, nele descreveremos a tipologia metodológica da pesquisa realizada para fundamentação de nossa dissertação que tem como foco a importância das formações contínuas de professores relacionadas ao desenvolvimento didático pedagógico dos docentes do município de Aquiraz.

Como narrado na introdução desse trabalho, é de cunho qualitativo, documental e fundamentado em uma exploração participativa que se deu para averiguação das concepções dos professores sobre os saberes experienciais desses, diante disso, temos que mostrar as relações do docente com o ambiente em que atua, assim como o discurso que utiliza em sua profissão pedagógica.

Sendo assim, nos remetemos a necessidade de utilizar uma metodologia construída de diferentes formas de investigação, isso se dar pelo fato de que esta pesquisa apresenta como objetivo o aspecto formativo, de modo a contribuir para a avaliação do grupo de estudo em que os participantes estão vinculados ao foco de investigação, formações de professores.

Outro fator relevante a ser ressaltado é o de que esta pesquisa estar vinculada a proposta de "formação continuada" adotada pela Secretaria de Educação do município de Aquiraz respaldado no pensamento de Palma (2005) que menciona: 
O enfoque crítico-dialético será adotado como abordagem em nosso projeto, pois, apresenta uma situação de rompimento com determinadas visões paradigmáticas, ao mesmo tempo tem o propósito de oferecer por superação, um contraponto epistemológico das formas tradicionais de cunho positivistas, propondo o enfoque crítico dialético, que utiliza também os métodos qualitativos dentre os quais se destaca a pesquisa ação, que está sendo desenvolvida dentro do grupo de estudo (PALMA, 2005, p. 16).

No pensamento do autor encontramos a metodologia adequada para desenvolvimento do objeto de pesquisa, pois, estamos investigando as visões paradigmáticas e as relacionar a prática pedagógica dos professores do município supracitado, além de investigarmos a ação do currículo presente no desenvolvimento profissional desses docentes utilizados como grupo de estudo, sendo assim, nossa pesquisa é de ação, observação e pequena ${ }^{18}$ intervenção.

Para fundamentar o pensamento que esta pesquisa se trata de uma construção com base nos princípios de Pesquisa-ação, buscamos o conceito de Kincheloe (1997) que afirma:

A pesquisa-ação, que é crítica, exonera os elementos positivistas de racionalidade, objetividade e de verdade absoluta, e que deve pressupor a exposição entre valores pessoais e práticos, porque ela não quer apenas compreender ou descrever o mundo que investiga, mas transformá-lo, devendo gerar um processo de reflexão crítica coletiva (KINCHELOE, 1997, p. 74).

Podemos assim, constatar que realmente estamos desenvolvendo uma pesquisaação, e que os estudos dos pesquisadores colocados nos três primeiros capítulos fundamentaram nosso foco de pesquisa, além de que, esse quarto só irá fortalecer a ideia de que a pratica docente necessita de continuas formações para transmissão de conhecimentos renovados e repassados aos discentes assistidos. 
Pertinente dizer que nossos procedimentos metodológicos foram construídos levando em conta a consideração do processo histórico da formação continuada dos sujeitos da pesquisa que pegamos como grupo de estudo, assim, descreveremos os motivos que levaram a Secretaria de Educação promover constantes formações de professores objetivando uma melhoria do sistema educacional do município de Aquiraz.

Essa pesquisa teve início quando nos matriculamos no curso de mestrado, no ano de 2014, ao recebermos os seminários aplicados mensalmente, o pensamento sobre o tema foi se aprofundando, no ano de 2016, delimitamos definitivamente o tema a ser pesquisado após desenvolvermos o Projeto de Pesquisa analisado por um professor de metodologia do trabalho cientifico.

Certamente que enfrentamos várias barreiras para descrição desse trabalho, mas, estávamos convictos e começamos a separar os teóricos que o fundamentaria e como seria desenvolvido no município do qual o pesquisador faz parte, assim, procuramos a Secretaria de Educação para solicitar seu consentimento de o desenvolver.

Outro fato é que queríamos partilhar com os colegas de profissão o conhecimento sobre currículo, didática pedagógica e a importância das formações.

\section{PROBLEMA DA PESQUISA}

Ao definirmos o objeto de pesquisa, procuramos a problemática que se relacionasse a ele e que nos servisse de motivação para uma pesquisa cientifica. Ao conversarmos com colegas participantes das formações de professores, percebemos algumas insatisfações, com bases nessas, organizamos os passos a serem tomados para realização dessa dissertação de mestrado a ser defendida.

Verificamos que havia no município de Aquiraz, urgência de se construir um currículo didático pedagógico que favorecesse ao desempenho escolar satisfatório dos educandos do citado município. 
Outro fator que deveríamos verificar seria a participação dos docentes na organização, elaboração e implantação de um currículo que melhorasse significativamente o desempenho desejado, a fim de se garantir a legitimidade desse projeto audacioso que precisava da participação ativa dos docentes.

Primeiro passo tomado foi procurarmos a Secretaria de Educação, lá conversarmos com o responsável pela Secretaria, levamos ao conhecimento desse, nosso projeto de pesquisa, esse foi plenamente aceito, e começamos a traçar os passos seguintes, escolha do local e sujeitos de nosso foco de pesquisa.

Ao entrarmos em contato com os sujeitos da pesquisa, acordamos com eles, encontros mensais, esses seriam quando os docentes participassem das formações de professores na Secretaria de Educação para que fizéssemos nossas observações de como eram dadas e como eram recebidas pelos professores.

A partir desses passos, escolhemos a literatura sobre o assunto em pesquisa abrangendo a carreira profissional dos professores como: formação docente, epistemologia docente, teorias/abordagens da educação sobre o processo de ensinoaprendizagem, teoria curricular, construção de currículo, avaliação, conflitos interpessoais, conteúdo específico, esses plenamente descritos nos primeiros capítulos de nosso trabalho.

Após a escolha da literatura, começamos a elaboração de questionários com perguntas abertas e fechadas que seriam utilizadas sistematicamente.

Assim, definimos nossa problemática com indagações pertinentes relacionadas as formações de professores como: Que saberes se constrói com as formações de professores? Quais suas origens? De que maneira os docentes se apropriam dos saberes e os transformam em conhecimento e os articulam na prática pedagógica conhecendo os currículos e os utilizam?

Mediante a problemática levantada, traçamos meios de prosseguirmos com nosso trabalho e fundamentar a importância das formações de professores, organização, construção e implantação de um currículo, sendo ele um meio e o próprio modo de 
refletir e promover uma formação continuada dos professores do município de Aquiraz.

Relevante observar que à medida que os planejamentos da pesquisa iam sendo colocados em práticas, surgiam dúvidas e questionamentos por parte do grupo observado levando-nos a constantes avaliações da proposta elaborada para sistematização de nossa pesquisa.

Procuramos depoimentos dos professores sobre as formações, eles testemunharam que todo início de ano letivo, existe uma ${ }^{19}$ semana pedagógica, nela são discutidas mudanças necessárias no currículo, essas fortalecem o objetivo inicial de (re) significar os conhecimentos dos professores, estes fundamentais para execução de ensinamentos por parte dos docentes aos discentes matriculados no município em pesquisa.

Assim, podemos constatar que o município valoriza o conhecimento renovado dos professores, pois, o processo de formação ocorreu durante todos os meses que nos encontramos com o grupo em pesquisa, elas foram pautadas em artigos, livros presentes na literatura, mantendo um vínculo com as teorias educacionais, teorias de currículo e análise do modelo adotado no município.

Após muitas discussões, o grupo de professores reconheceu a necessidade de se ter como orientação uma teoria crítica da educação para que os educandos recebam uma educação de qualidade.

Percebemos que no início dos contatos, os professores mostravam insatisfação em participar das formações de professores, mas, aos poucos, foram modificando seu pensamento em relação a sua participação nas formações continuadas, pois, viram que os formadores traziam visões baseadas em inovações propostas em documentos oficiais e pesquisas de currículo, didática e pratica pedagógica.

Assim, percebemos que a problemática levantada seria fácil de solucionar, após as observações, traçamos nossos objetivos e as medidas a serem tomadas e começamos, como primeiro passo: elaboramos um oficio de solicitação para participar 
das formações de professores, projeto da Secretaria de Educação, iniciamos a estruturação das perguntas que aplicaríamos aos sujeitos da pesquisa, esboçamos nossos pensamentos e a agenda a ser seguida nesse trabalho dissertativo.

$\mathrm{Na}$ execução de nosso primeiro passo, ao chegarmos na Secretaria de Educação com nosso ofício, fomos bem recebidos e nos mostraram as propostas do projeto das formações traçadas por esse órgão, a ideia era maravilhosa, assim, não entendemos o real motivo dos professores mostrarem resistências e insatisfação para participarem das formações.

O Projeto formulado pela Secretaria de Educação tem a seguinte estrutura: o grupo de professores do município são divididos por series/anos, uma vez por mês cada grupo vai à Secretaria de Educação para participar de uma formação continuada, essa é direcionada por um formador com orientações do nível que os professores atuam, assim, mantem dentro de cada grupo: temas, subtemas, assuntos e objetivos que orientem o planejamento das aulas desse grupo de professores.

Portanto, nosso projeto de pesquisa só viria reforçar a excelência do projeto de formação adotado pela Secretaria de Educação, precisávamos apenas motivar os docentes para sua participação e mostrar que era de suma importância sua participação para a criação e implantação de currículo que viesse qualificar sua didática pedagógica em sala de aula.

Assim, escolhemos um grupo para participação em nossa investigação num total de doze professores: 04 da pré-escola, 04 do ensino fundamental I e 04 do ensino fundamental II, conversamos e prontamente aceitaram participar de nosso trabalho.

\section{OBJETIVO GERAL}

Para traçar objetivos de uma pesquisa empírica fundamentados na importância do currículo, didática e avaliação de um sistema educacional precisamos conhecer o significado dos conceitos dessas palavras relacionadas a qualidade da educação. 
Antes da elaboração de nossos objetivos, fundamentamos esses conceitos em Documentos Oficiais e estudos de teóricos de suma importância para o processo de ensino e aprendizagem.

Sabemos agora que, o desenvolvimento curricular é uma formalização no âmbito da educação ou da formação profissional dos processos de construção, implantação e avaliação de ensino-aprendizagem nos sistemas educativos ou de formação profissional com implícita a as melhorias permanentes ao nível teórico ou pratico de um currículo elaborado e implantado e esse passa por cinco fases que são: 1) analise; 2) projeto; 3) seleção; 4) formalização; 5) avaliação (revisão/melhorias).

Baseados nessas fases, elaboramos nosso objetivo como sendo: identificar e analisar os conhecimentos que os professores têm para construir seus currículos em um processo de formação continuada e como estes repercutem na sua ação pedagógica.

O projeto de formação continuada implantado no município de Aquiraz tem como temática a formação inicial e desenvolvimento profissional contínuo de professores interagindo possibilidades de pesquisa, ensino e discussão de currículo e práticas didáticas aplicadas no processo de ensino-aprendizagem.

Ao procurarmos informações sobre as formações de professores, nos comunicaram que havia um projeto foi construído por técnicos educacionais, e, é coordenado por grupo de professores designados para ministrar as formações com propósito de gerar benefícios para professores e educandos que fazem parte do sistema educacional de Aquiraz.

Dentro desse processo de formações do município, participam professores da préescola, fundamental I e II em diferentes datas separadas por níveis e as formações dadas pelas pessoas determinadas pela Secretaria de Educação. 


\section{OBJETIVOS ESPECÍFICOS}

A partir do objetivo traçado para a pesquisa junto aos docentes do município de Aquiraz, procuramos identificar a importância das formações para o grupo de estudo que escolhemos como sujeitos.

No decorrer da descrição desse trabalho percebemos fatores que influenciam a atuação didática docente do citado município, queríamos indagar por exemplo, se as formações que recebem são baseadas nos currículos definidos pela Secretaria de Educação e se estão fundamentados pela legislação em vigor. Sendo assim, traçamos nossos objetivos específicos trazendo indagações sobre saberes:

- Identificar os saberes docentes e suas origens;

- Perceber a apropriação dos docentes e seu conhecimento sobre currículo e prática docente;

- Analisar a articulação dos professores em relação elaboração de currículo e sua prática em sala de aula;

- Encontrar relação entre currículo e prática pedagógica e se os docentes adquirem seu saber do próprio fazer docente ou se é baseado nas formações recebidas pela Secretaria de Educação em seu projeto de "Formação Contínua;

- Indagar sobre a reflexão do docente quanto sua prática pedagógica para análise de um sistema de avaliação adotada pelo município pesquisado.

Ao colocarmos nossos objetivos podemos perceber que os saberes dos docentes do grupo de estudo são oriundos das experiências de seus trabalhos cotidianos alicerçando assim, as suas práticas e competências profissionais e a constante busca de conhecimento sobre currículo e pratica pedagógica, essas renovadas com as constantes formações de professores adotadas pelo município de Aquiraz na busca de qualidade de ensino do município supracitado.

Dessa forma, podemos destacar a importância das práticas pedagógicas docentes na construção da identidade do professor, aqui entendidas como um lugar onde se produzem saberes adquiridos pela reflexão prática, por meio das atividades cotidianas 
de ensino ministrado aos educandos e, acima de tudo, os docentes precisam das formações para uma prática docente de qualidade.

\section{METODOLOGIA}

A metodologia de pesquisa que aplicamos foi norteada pela teoria crítica, com uma abordagem participativa, com a vinculação de diferentes procedimentos de coleta de informações, sendo eles: questionário, observação das aulas e entrevista feita pelo pesquisador aos professores do referido município que aceitaram participar de nosso trabalho.

Dessa maneira, os professores escolhidos são dos seguintes níveis/serie/ano: préescola, Ensino Fundamental I e Ensino Fundamental II, todos participam do Projeto de Formação ministrado pela Secretaria de Educação do município pesquisado, esse tendo como propósito, construir e implementar um currículo vinculado a área de atuação do docente para que haja qualidade de ensino nas escolas municipais contemplando a Educação Infantil e o Ensino Fundamental I e II.

Os recursos financeiros para o projeto de formação são disponibilizados pela Secretaria de Educação, ele é ministrado por professores que compõem o quadro da Identidade citada, as formações acontecem uma vez por mês, no dia que é destinado ao planejamento escolar dos docentes, assim, eles se deslocam da escola para a Secretaria de Educação e passam o dia em Formação.

Nosso grupo de estudo é composto por 12 professores: 04 da Educação Infantil, 04 do Fundamental I e 04 do Fundamental II, informamos que participamos das formações dos 12, que aconteceram em dias diferentes, observamos e após estas observações elaboramos os questionários aplicados a esse grupo de estudo. Segue quadro relacionando os docentes que são nomeados por letra e número como modo de preservação de suas identidades: 
Quadro 26: Perfil dos Professoras Sujeitos da Pesquisa. Aquiraz - 2016.

\begin{tabular}{|l|l|l|}
\hline Professores & Modalidade de atuação & Quantidade de participantes \\
\hline $\mathbf{P}_{\mathbf{1}}, \mathbf{P}_{\mathbf{2}}, \mathbf{P}_{\mathbf{3}}, \mathbf{P}_{\mathbf{4}}$ & Educação Infantil & 04 \\
\hline $\mathbf{P}_{\mathbf{5}}, \mathbf{P}_{\mathbf{6}}, \mathbf{P}_{\mathbf{7}}, \mathbf{P}_{\mathbf{8}}$ & Ensino Fundamental I & 04 \\
\hline $\mathbf{P}_{\mathbf{9}}, \mathbf{P}_{\mathbf{1 0}}, \mathbf{P}_{\mathbf{1 1}}, \mathbf{P}_{\mathbf{1 2}}$ & Ensino Fundamental II & 04 \\
\hline
\end{tabular}

Fonte: ARAUJO, M. V. de. Escolha da participação o pesquisador

Constatamos que as formações geram aprendizagens aos docentes e possibilitam uma continuidade de ensino qualificado em sua prática pedagógica.

Podemos certificar que ao realizarmos esse trabalho baseado em pesquisas, envolvendo uma iniciação cientifica contribuindo para um campo fértil a indagações merecedoras de serem investigadas para promoção de novos conhecimentos para uma prática pedagógica de qualidade pautada no currículo e avaliação dos educandos do município tomado para investigação do tema abordado.

Nosso trabalho durante sua organização, passou por várias etapas, seu início se deu quando nos matriculamos no curso de mestrado e escolhamos o tema a ser pesquisado, durante o curso escrevemos artigos sobre temas diversos, mas todos relacionados a educação, didática pedagógica e abordagens metodológicas.

Podemos dizer que o curso nos trouxe uma mudança de olhar referente a prática docente e possibilitou a verificação da importância das formações continuadas para o processo de ensino-aprendizagem do município escolhido como campo de nossa observação, estrutura e sistematização desse trabalho.

O local escolhido para coleta de dados foi a Secretaria de educação, nela ocorre as formações de professores e o grupo de pesquisa a frequenta, vimos nelas uma constante avaliação do currículo, abordagens e tendências pedagógicas e que os gestores estão preocupados com a qualidade de ensino, outro fator que percebemos foi a insatisfação dos professores quanto a sua valorização, motivo que os levam a não quererem participar dessas formações. 
Como mencionamos, este trabalho passou por várias etapas como: observação, aplicação de questionários, entrevistas, sendo assim, além da secretaria, utilizamos como campo de pesquisa as escolas de atuação do grupo de pesquisa, após as leituras de pesquisadores do tema, sistematizamos as informações obtidas nos questionários, essas colocaremos posteriormente.

Tivemos um total de 12 participações nas formações sendo: 04 de educação infantil, 04 de ensino fundamental I e 04 de ensino fundamental II, observamos 09 aulas: 03 em cada sala das modalidades mencionadas, aplicamos questionários aos 12 professores que formaram o grupo de pesquisa, quantidade igual de entrevistas, além desses passos, realizamos várias pesquisas bibliográficas e consultas à documentos oficiais sobre educação e sua legislação.

\section{NATUREZA DA PESQUISA}

Quando escolhemos o grupo de pesquisa, começamos a fazer uma rigorosa observação nos campos de atuação desse, começamos com a solicitação à Secretaria para realização de nosso trabalho, depois, a participação nas formações, dentro delas escolhemos os participantes, a eles aplicamos questionários, entrevistas e solicitamos permissão para observar suas aulas.

A maior dificuldade foi reunir os professores selecionados em um único momento, por esse motivo, as perguntas de nosso questionário foram estruturadas em categorias, após a análise das respostas, sistematizamos às de forma específica. A seleção do grupo de participação se deu por serem professores efetivos e o critério principal, todo grupo participa do projeto de formações da secretaria de educação.

Pertinente descrever o propósito de averiguação da carreira profissional dos professores participantes e seus pensamentos sobre considerações a respeito da formação continuada e consequentemente da implementação curricular, assim, construímos um conjunto de perguntas com função de nortear a estrutura dos questionários e entrevistas. Seguimos o pensamento de Richardson (2008) que diz: 
O questionário oferece algumas vantagens, ele permite obter informações de um grande número de pessoas simultaneamente ou em um tempo relativamente curto (RICHARDSON, 2008, p.205).

O pensamento desse autor mostra que o questionário traz informações que possam fundamentar uma pesquisa, pois, um grupo de pessoas respondem diversificadamente as perguntas aplicadas, nelas eles deixam seus pensamentos e ponderações.

O questionário aplicado ao nosso grupo de pesquisa combinou perguntas abertas e fechadas, somando um total de 10 questões onde o método aplicado foi o direto, entregue em mãos aos sujeitos da pesquisa e registrado o dia da devolução.

Ao entregar o questionário, explicamos o que constava no termo de livre esclarecimento, solicitamos a participação de todos os escolhidos para o grupo de pesquisa, colocamos para eles o critério de seleção, ficamos felizes com o percentual de aceitação num total de $100 \%$ dos que foram escolhidos.

Como mencionamos anteriormente, além do questionário, realizamos observações, pois, consideramos que a observação é um referencial significativo e necessário porque faz parte da articulação dos conhecimentos dos professores durante as suas aulas baseados em:

Quadro 27: Significação das Observações dos Sujeitos da Pesquisa

\section{a) são baseados em ações não faladas;}

b) seus atos e expressões são corporais são relevantes.

Fonte: ARAUJO, M. V. de. Baseado nas observações de sala

Das observações tiramos a conclusão de que não é suficiente fazer perguntas, é necessário observar o que eles fazem e como relacionam seus conhecimentos à medida que põem em prática aos seus discentes, ou seja, suas experiências. 
Buscando o objetivo para realizar a observação, encontramos uma explicação na citação de Watson-Gegeo (1988) que diz:

Um dos objetivos da observação, é de descrever e interpretar ou explicar o que as pessoas fazem em um determinado ambiente (sala de aula, por exemplo), os resultados de suas interações, e o seu entendimento do que estão fazendo, ou seja, por meio da observação continua das aulas e das reuniões podemos ressaltar elementos importantes para a análise dos saberes experienciais construídos pelos professores durante a construção e implementação do currículo (WATSON-GEGEO, 1988, p.576)

Devemos registrar que a observação de sala de aula não teve intuito de comparar a ação pedagógica entre os docentes do grupo de pesquisa, pois, compreendemos que cada sujeito em sua profissão possui uma forma de agir, vindo da sua trajetória de vida, e que esse processo formativo deve ser respeitado. Buscando um autor para fundamentar esse pensamento, encontramos a citação de Wielewicki, (2001) segundo esse autor:

Entender a construção do sujeito contribui no ato de tentar identificar o motivo pelos quais agem de determinada maneira, e sobre o que representam como papel do professor no contexto educacional. Portanto, talvez o grande trunfo da etnografia pós-moderna seja reconhecer que existem diferenças e que elas não precisam ser eliminadas (WIELEWICKI, 2001, p. 31).

Assim, durante as observações naturalmente que não interferimos nas aulas, assistimos 02 aulas em cada nível de ensino de cada professor e delas tiramos informações significativas para nossa pesquisa que relataremos no próximo tópico com os procedimentos utilizados em nossa pesquisa. 


\section{INSTRUMENTOS E PROCEDIMENTOS DA PESQUISA}

Como mencionado nossa pesquisa se utilizou de procedimentos diversificados para sua fundamentação, ressaltamos no tópico anterior a aplicação de questionários e a observação de sala de aula. Para fundamentar esse tipo de procedimento nos reportamos aos estudos de Basso (1999), que afirma sobre a observação:

A observação pode ser representada por meio de várias modalidades técnicas. Desta forma, a categoria empregada foi sistemática, isto é, quando planejada, estruturada (BASSO,1999, p. 85).

A citação mostra a importância da observação, além disso, que deve seguir técnicas para que não se perca as informações adquiridas com esse procedimento, no caso de nossa pesquisa, utilizamos um protocolo de observação que descreveremos nos apêndices.

Outro instrumento selecionado para sistematização de informações sobre o tema focal foi a entrevista aos sujeitos do grupo de estudo onde foi selecionado professores de modalidades de ensino diferentes, portanto, com diferentes opiniões e com o objetivo de obtermos relatos sobre os objetivos traçados para esse trabalho.

Este pensamento vem fundamentado nos estudos de Nishiiye (2009), segundo esse autor, os aspectos da entrevista apontam para:

Diante destes aspectos, vemos como procedente, pois, estudos anteriores apontaram uma divisão no grupo sobre a concepção do processo de ensino-aprendizagem (NISHIIYE, 2009, p. 85).

Para realização da entrevista, seguimos um roteiro semi-estruturados com questões mais próximo da realidade que os professores vivenciam nas formações continuadas ministrada no município de Aquiraz.

A entrevista possibilitou uma aproximação do pesquisador com o grupo de estudo dentro do contexto do objeto de pesquisa, ela foi gravada e será descrita em síntese, 
ela, com intuito de deixar o entrevistado expressar sua opinião sem nenhum tipo de constrangimento.

Assim utilizamos os métodos mencionados: questionários, entrevistas e observações das salas de aula dos sujeitos de nossa pesquisa e seu objeto.

\section{PROCEDIMENTOS METODOLÓGICOS}

Nosso procedimento metodológico ou metodologia utilizada no local de pesquisa, detalharemos nesse tópico, considerado o mais importante da pesquisa, pois, a partir dele, chegaremos as considerações finais com os resultados alcançados em relação ao objeto pesquisado: "Formação de Professor, Currículo e Práticas Pedagógicas no Município de Aquiraz"

Iniciaremos descrevendo como elaboramos a ficha de observação e os métodos em que foram respaldadas, essa ficha foi dividida em quatro procedimentos e três atitudes, esses serão mostrados nos quadros que se seguem:

Quadro 28: Procedimentos da Observação de Sala de Aula

\begin{tabular}{|l|l|}
\hline Procedimentos & Sigla utilizada \\
\hline Iniciativa Docente & I. Doc. \\
\hline Resposta Discente & R. Disc. \\
\hline Iniciativa Discente & I. Disc. \\
\hline Resposta Docente & R. Doc. \\
\hline
\end{tabular}

Fonte: ARAÚJO: M. V. de. “O próprio pesquisador” (2016)

Para cada categoria dos procedimentos utilizamos três tipos de atitudes descritas no quando abaixo e especificada posteriormente.

Quadro 29: Atitudes das Categorias da Observação

$\begin{array}{lll}\text { Categoria } & \text { Atitude }\end{array}$




\begin{tabular}{l|l|}
$\begin{array}{l}\text { Iniciativa } \\
\text { docente }\end{array}$ & Unilateral, Reflexiva, Espontânea. \\
\hline $\begin{array}{l}\text { Resposta } \\
\text { Docente }\end{array}$ & Negativa, Reflexiva, Indução \\
\hline $\begin{array}{l}\text { Iniciativa } \\
\text { Discente }\end{array}$ & Antecipação Negativa, Antecipação Reflexiva, antecipação \\
\hline $\begin{array}{l}\text { Resposta } \\
\text { Docente }\end{array}$ & Sem Consideração, Receptiva. \\
\hline
\end{tabular}

Fonte: ARAÚJO: M. V. de. “O próprio pesquisador” (2016)

Para entendimento do procedimento e atitudes utilizados na observação, podemos respaldar que as aulas dos professores sujeitos de nossa pesquisa, eram baseadas nos parâmetros dentro das atitudes que descreveremos a seguir.

- Iniciativa Docente: Unilateral (indutiva): nela somente o professor se expressa, a aula era um monologo; Reflexiva: quando o professor promovia a contextualização do conteúdo por meio de questionamento e inquietação dos educandos; Espontânea: no momento em que não há intenção por parte do professor de ensinar um conteúdo, age sem planejamento algum durante a aula.

- Resposta Discente: negativa: quando o aluno se recusava a participar das atividades propostas, essa atitude em quase todos os níveis foi observada pelo pesquisador; Reflexiva: a partir das problematizações propostas pelo professor, os discentes pensaram e responderam de maneira coerente, essa atitude percebida somente em algumas turmas; Indução: os discentes completavam as palavras ditas pelo docente ou apenas as reproduziam.

- Iniciativa Discente: Antecipação Negativa: os educandos mesmo antes do professor colocar a proposta do que seria realizado, havia uma negação em realiza-la; Antecipação Reflexiva: quando o discente argumentava algo que iria estudar mesmo antes do professor questioná-lo; Antecipação Espontânea: quando o aluno sugeria algum tipo de atividade antes do professor propor, normalmente eles gostavam muito de realizar essas atividades. 
- Resposta Docente: percebemos que sem consideração, o professor não dava a mínima atenção so discente, foram poucas vezes que observamos essa atitude; Receptiva: observamos na maioria das observações de sala que o docente atendia a todos os alunos considerando o que o educando fazia, falava a respeito da colocação dele e tentava contextualizar o pronunciamento do estudante.

Analisando o resultado de nossa sistematização perante as ${ }^{20}$ observações acima relacionadas, podemos dizer que as informações obtidas foram de grande importância para percebermos que os professores que participam das formações, a maioria aproveita as didáticas nelas sugeridas e que dão resultados significativos e a minoria que não as utilizam, suas aulas são monótonas e não despertam interesse dos educandos.

Portanto, podemos dizer que com as informações obtidas tanto nos questionários que detalharemos posteriormente, como nas observações já descritas anteriormente e as entrevistas realizadas, esses métodos trazem uma análise dos conteúdos expostos no início de nossa pesquisa e a sistematização dessas informações estão correlacionadas com o tema escolhido e que norteia essa investigação.

\section{DADOS COLETADOS E ANÁLISE DAS INFORMAÇÕES DOS QUESTIONÁRIOS APLICADOS}

O segundo instrumento utilizado em nosso procedimento metodológico foi a aplicação e análise de questionários centrados em quatro temas principais e as informações coletadas foram colocadas em categorias que encontramos nas respostas dos professores e nas referências teóricas utilizadas.

Ressaltamos que para manter o anonimato dos sujeitos da pesquisa, eles serão representados por números e letras em todas as aparições dessa pesquisa. Os temas principais utilizados no questionário aplicado estão no quadro abaixo: 
Quadro 30: Temas Utilizados nos Questionários

a) Carreira docente com os dados pessoais e profissionais;

b) Conhecimentos sobre a construção do currículo;

\section{c)Desenvolvimento curricular;}

d)Auto avaliação e avaliação do currículo.

Fonte: ARAÚJO, M. V. de. Baseado nas respostas dos professores (2016)

A temática da (a) carreira docente com dados pessoais e profissionais dos sujeitos da pesquisa foi composta por dez perguntas, sendo, oito fechadas e duas abertas, no quadro a seguir colocaremos a escala e identificação dos professores:

Quadro 31- Escala e Identificação dos Sujeitos da Pesquisa. Aquiraz - 2016.

\begin{tabular}{|c|c|c|c|c|}
\hline Professores & Idade & Formação & $\begin{array}{l}\text { Anos de } \\
\text { Docência }\end{array}$ & $\begin{array}{l}\text { Tempo de Atuação } \\
\text { no município }\end{array}$ \\
\hline $\mathbf{P}_{1}$ & 51 & $\begin{array}{l}\text { Pedagogia, } \quad \text { ESP: } \\
\text { Port. /lng. }\end{array}$ & 27 anos & 14 anos \\
\hline $\mathbf{P}_{2}$ & 36 & $\begin{array}{l}\text { Pedagogia, Esp:Port. } \\
\text { / Gest. }\end{array}$ & 07 anos & 04 anos \\
\hline $\mathbf{P}_{3}$ & 33 & $\begin{array}{l}\text { Pedagogia Esp: mat. / } \\
\text { Ciênc. }\end{array}$ & 05 anos & 04 anos \\
\hline $\mathbf{P}_{4}$ & 39 & Pedagogia, educ. Inf. & 10 anos & 04 anos \\
\hline $\mathbf{P}_{5}$ & 43 & $\begin{array}{l}\text { Pedagogia, Educ. } \\
\text { Esp. }\end{array}$ & 15 anos & 08 anos \\
\hline $\mathbf{P}_{6}$ & 53 & $\begin{array}{l}\text { Curso Ed. Física/ } \\
\text { Educ. Esp. }\end{array}$ & 18 anos & 14 anos \\
\hline $\mathbf{P}_{7}$ & 40 & $\begin{array}{l}\text { Pedagogia, } \\
\text { curso/Libras }\end{array}$ & 17 anos & 08 anos \\
\hline $\mathbf{P}_{8}$ & 34 & $\begin{array}{l}\text { Pedagogia, Esp: Geo. } \\
\text { / Hist. }\end{array}$ & 10 anos & 04 anos \\
\hline
\end{tabular}




\begin{tabular}{|l|l|l|l|}
\hline $\mathbf{P 9}$ & 32 & $\begin{array}{l}\text { Educação esp. / 04 anos } \\
\text { Educ. Inf. }\end{array}$ & 03 anos \\
\hline $\mathbf{P}_{\mathbf{1 0}}$ & 31 & $\begin{array}{l}\text { Pedagogia, Educ. 02 anos } \\
\text { Rel. / Artes }\end{array}$ & 1 ano \\
\hline $\mathbf{P}_{11}$ & 42 & $\begin{array}{l}\text { Pedagogia, Educ. Inf. 13 anos } \\
\text { / Espec. }\end{array}$ & 08 anos \\
\hline $\mathbf{P}_{\mathbf{1 2}}$ & 36 & $\begin{array}{l}\text { Pedagogia, mat. / 05 anos } \\
\text { Cienc. / Esp. }\end{array}$ & 06 meses \\
\hline
\end{tabular}

Fonte: ARAÚJO, M. V. de. Baseado nos dados fornecidos pela Secretaria de Educação (2016)

Podemos ver no quadro acima que a idade dos professores varia de 31 a 51 anos, isso demonstra um grupo bem diversificado na faixa etária e sua carreira profissional professores iniciantes e experientes.

As informações adquiridas mostraram que esse grupo passou por formação inicial com currículos e orientações diferentes para os cursos de formação de professores, talvez seja o motivo de termos observado didáticas diversificas na aplicação de suas aulas.

A experiência vivenciada por esse grupo é bastante diversificada, mas, alguns estão no início de sua profissionalização docente, tiveram suas formações em instituições particulares, alguns na mesma instituição, segundo disseram em suas entrevistas, esse fato, de certa maneira nos faz inferir que possuem uma formação inicial no mesmo contexto cultural e institucional.

Outro fator percebido nas entrevistas com o grupo foi a evidência de fatos e aprendizagens em comum no momento em que analisaram e discorreram sobre sua formação inicial. Esse fato de certa forma possibilita verificar uma troca de relatos em comum como as críticas e indicadores de avanços de seus conhecimentos na atualidade. 
Apesar de constatarmos que o grupo de pesquisa contém professores com vários anos de atuação, outros iniciando, o ensino das áreas profissionais com essa formação especifica são concursados na rede municipal recentemente, pois, o maior tempo de atuação nesse é de quatro anos.

O quadro 31 nos mostrou que os professores possuem pós-graduação na área da educação, o que podemos deduzir que com elas buscaram atualizar seus conhecimentos docentes, ou seja, estão interessados na carreira profissional docente para dar qualidade as didáticas aplicadas nos níveis de sua atuação.

Quando indagamos ao grupo de estudo sobre formações continuadas, a maioria do grupo mencionou se manifestou favorável a elas, pois quem participa, segundo os professores abre um leque de possibilidades de ampliação de conhecimentos em uma infinidade de aspectos. Esse pensamento é fundamentado nos estudos de Imbernon (2010) que diz:

A formação continuada docente se encontra em alguns grandes eixos, entre eles consiste na a troca de experiências entre iguais para tornar possível a atualização em todos os campos de intervenção educativa e aumentar a comunicação entre os professores (IMBERNON, 2010, p.50).

Podemos constatar que a citação acima intensifica a importância da formação continuada tão bem ressalta em várias partes desse trabalho, além de fortalecer os conhecimentos e renová-los, dar uma qualidade ao processo de ensinoaprendizagem.

Por fim, os professores testemunharam também que embora seja cansativa as formações do projeto da Secretaria de Educação, trazem melhorias para suas práticas didáticas, o que demonstra uma confiança e interesse por parte da maioria dos professores do município de Aquiraz, pois, a participação deles é voluntaria, ou seja, não são obrigados delas participarem. 
Partiremos agora para análise do segundo tema abordado no questionário aplicado: (b) "Conhecimentos sobre a Construção do Currículo", quando utilizamos esse tema, estávamos pensando na melhoria que traria para a coleta de dados das informações do objeto de pesquisa referente ao tema currículo.

Assim, fizemos a seguinte pergunta: As formações de professores recebidas no projeto da Secretaria de Educação colaboram em sua atuação profissional? As respostas sistematizadas colocaremos no quadro abaixo:

Tabela 05: Contribuições das Formações para a atuação profissional de docência

\begin{tabular}{|l|l|l|l|}
\hline Categoria & Professores & $\begin{array}{l}\text { No de } \\
\text { respostas }\end{array}$ & $\%$ \\
\hline $\begin{array}{l}\text { Contribuiu com o processo de ensino- } \\
\text { aprendizagem e estruturação dos }\end{array}$ & $\mathrm{P}_{09} ;$ & $33,33 \%$ \\
$\begin{array}{l}\text { conteúdos } \\
\text { Contribuiu na mudança de concepção }\end{array}$ & 04 & \\
$\begin{array}{l}\text { da Educação, e na fundamentação } \\
\text { teórica }\end{array}$ & $\mathrm{P}_{07} ;$ & 02 & 16,66 \\
\hline $\begin{array}{l}\text { Colaborou com o relacionamento com } \\
\text { os demais professores }\end{array}$ & $\mathrm{P}_{02}, \mathrm{P}_{08}$ & 02 & 16,66 \\
\hline $\begin{array}{l}\text { Não contribuiu por compreender que } \\
\text { atua somente com conceitos já } \\
\text { conhecido (repetição nas formações) }\end{array}$ & & 02 & 16,66 \\
\hline $\begin{array}{l}\text { Não participa das formações, pois, } \\
\text { entrou no município esse ano }\end{array}$ & $\mathrm{P}_{10} ; \mathrm{P}_{12}$ & 02 & 16,66 \\
\hline
\end{tabular}

Fonte: ARAÚJO, M. V. de. Baseado na sistematização das respostas dos professores sujeitos da pesquisa

Das respostas dadas pelo grupo de estudo vimos que a categoria mais evidente foi a da especificidade docente em que 04 professores afirmaram que as formações contribuíram com o processo de ensino-aprendizagem, juntamente com a questão 
curricular, com sua estruturação dos conteúdos que aplicam em suas práticas pedagógicas nas modalidades de ensino que atuam esse grupo correspondem a $33,33 \%$ do grupo de estudo.

Vimos que os demais professores se dividiram nas demais respostas respondendo que as formações favoreceram diretamente ao conhecimento das concepções sobre a área de sua atuação, contribuindo assim, na mudança de suas aulas por meio de sua fundamentação teórica dois professores assim se manifestaram correspondendo a $16,66 \%$ dos sujeitos da pesquisa.

Outro grupo de dois professores relatou que o relacionamento com os demais colegas ficou bem melhor, graças as formações, pois a amizade entre eles foi consolidada e houve a troca de experiências que os ajudou na melhoria de suas didáticas pedagógicas, esse grupo corresponde a $16,66 \%$ dos professores.

Por fim, temos mais dois grupos que mencionou sobre as formações o seguinte, disseram que em nada contribui para sua pratica pedagógica participar delas, pois são enfadonhas e repetitivas, estes grupos são compostos por dois professores correspondendo a 16,66\% cada, devemos ressaltar que dois desses professores relatou que não participam das formações por que estão fazendo parte dos profissionais efetivos somente no ano em curso, e que, pretendem participar no próximo ano.

Ao discorremos sobre esse tópico sobre conhecimentos e construção do currículo, ressaltamos que os discursos dos professores pesquisados eram sobre seu modo de ensinar centrado no processo de ensino-aprendizagem, na estruturação dos conteúdos e suas aplicabilidades.

De acordo com as respostas obtidas nos questionários, buscamos um respaldo teórico para as colocações dos professores, encontramos apontamentos de Pacheco; Flores, 1999 , p. 19-20, estudos sobre conhecimentos, os autores ressaltam tipos de conhecimentos como: 
Quadro 32: Tipos de Conhecimentos para os Professores

\section{Conhecimento dos conteúdos;}

\section{Conhecimento pedagógico geral}

Conhecimento pedagógico do conteúdo;

\section{Conhecimento do currículo;}

\section{Conhecimento dos fins e dos propósitos educativos.}

Fonte: ARAÚJO, M. V. de. Baseado nos estudos de Pacheco; Flores 1999, p. 19-20

Salientamos que os conhecimentos abordados no quadro acima são fundamentados nos estudos dos autores mencionados e de Tardif (2002) que coloca:

Os conhecimentos produzidos com a prática profissional no momento que estão atuando em sala de aula, no momento que dão indicativos de que isso existiu ao salientarem ter modificado sua compreensão sobre o próprio pensamento da área, ou seja, das propostas educativas e da teoria que os orientam (TARDIF, 2002, p. 17).

Segundo o autor, os conhecimentos, contudo, não foram expostos diretamente pelos professores, eles estão envolvidos com sua prática, mas, se escondem, eles seriam: conhecimentos do contexto educativo; conhecimento dos alunos e das suas características.

Para aprofundamento do conceito de conhecimentos que envolve a carreira docente perguntamos aos pesquisados o seguinte: Como os conhecimentos foram abordados na construção do currículo a ser aplicado em suas práticas pedagógicas?

Procurávamos com essa indagação entender como os entrevistados apontam como os conhecimentos adquiridos foram abordados em suas práticas pedagógicas, a sistematização dessa será colocada no quadro que se segue e que demonstra a real participação dos docentes na construção do currículo, com uma mobilização de conhecimentos de diversas ordens como: 
Quadro 33: Diversas ordens de conhecimentos docentes

\section{Modo de sua atuação em sala de aula}

\section{Organização didática do conteúdo a ser aplicado}

Conhecimentos adquiridos em suas experiências docentes

Identificação das dificuldades apresentadas pelos discentes

Facilidade em dar sugestões praticas a serem utilizadas

Fonte: ARAÚJO, M. V. de. Baseado nos estudos de Tardif (2002, p. 39)

Ao sistematizarmos as respostas dos participantes da pesquisa sobre as abordagens que têm sobre conhecimentos envolvidos na construção do currículo a ser aplicado em sala de aula, constatamos que esses apontaram diversas ordens como se segue na tabela 06 , a seguir;

Tabela 06: Abordagens dos Conhecimentos na Construção do Currículo

\begin{tabular}{|l|l|l|l|}
\hline Categoria & Professores & $\begin{array}{l}\text { No } \\
\text { respostas }\end{array}$ & $\%$ \\
\hline $\begin{array}{l}\text { Sugestão na postura do professor } \\
\text { (atuação pedagógica) }\end{array}$ & $\mathrm{P}_{02}$ & 01 & $8,33 \%$ \\
\hline $\begin{array}{l}\text { Organização didática dos conteúdos } \\
\text { a serem aplicados }\end{array}$ & $\mathrm{P}_{03} ; \mathrm{P}_{04} ; \quad \mathrm{P}_{06} ;$ & 05 & $41,66 \%$ \\
\hline $\begin{array}{l}\text { Sugestões vindas de suas } \\
\text { experiências }\end{array}$ & $\mathrm{P}_{07}$ : $\mathrm{P}_{05}, \mathrm{P}_{08 ;}$ & 02 & $16,66 \%$ \\
\hline $\begin{array}{l}\text { Identificação das dificuldades ao } \\
\text { ensinar }\end{array}$ & $\mathrm{P}_{01} ; \mathrm{P}_{11}$ & 02 & $16,66 \%$ \\
\hline $\begin{array}{l}\text { Não opinou apenas observou, pois, } \\
\text { iniciou no ano em curso no município }\end{array}$ & $\mathrm{P}_{10} ; \mathrm{P}_{12}$ & 02 & $16,66 \%$ \\
\hline
\end{tabular}

Fonte: ARAÚJO, M. V. de. Baseado na sistematização das respostas dos professores sujeitos da pesquisa 
As respostas dadas pelos professores, mostraram que os conhecimentos adquiridos estão realmente interligados, refletem na sua forma de atuar em sala de aulas plenamente e na construção do currículo a ser aplicado.

Mostraram também que são vários aspectos envolvendo uma convergência e necessidade de crescimento profissional, identificando nesses aspectos de convergência a construção do currículo para um foco de necessidade dos saberes para formalização de um documento utilizado pela escola, o chamado PPP.

Diante dessa constatação de construção curricular, os sujeitos da pesquisa mobilizaram diretamente seu repensar em suas atuações com seus alunos nos diferentes níveis em que exercem seu magistério, assim, devem organizar os conteúdos para possibilitar uma motivação e aprendizagem de seus discentes.

Os sujeitos da pesquisa mostraram ainda que objetivos e finalidades devem estar interligados, pois assim, facilitam uma organização didática dos conteúdos aplicados, esse aspecto apareceu de forma expressiva em suas respostas. Os fatores mais favoráveis colocados pelos docentes, foi a necessidade de uma orientação de coordenação pedagógica em relação ao currículo elaborado com suas participações.

Pelas respostas dadas a indagação acima, podemos sistematizar as respostas com uma análise simples: didática pedagógica tem várias interligações, mas acima de tudo, a elaboração e implementação de uma grade curricular adaptada ao meio de vivencias dos educandos é primordial.

Outro fator importantíssimo é o da participação dos educadores nas renovadas formações, essas tão necessárias para a qualificação de uma educação que transforme os educandos que assistem.

Não podemos deixar de mencionar a relevância que assume o conteúdo na prática didática dos educadores, nossa pesquisa contou com professores de modalidades divergentes, mas, com uma visão de qualidade para a educação, mesmo sem a real valorização que merecem. 
Passamos agora a dissertar sobre outro tema abordado no questionário aplicado: (c) O Desenvolvimento do Currículo, nessa temática colocamos perguntas que se refere diretamente com a prática ao desenvolvimento de um currículo que contou com a participação de todos que fazem parte da instituição educacional.

Nesse tema colocamos a manifestação para a intervenção do docente diante de seus planejamentos. Assim, fizemos a seguinte pergunta: Como foi a introdução da proposta pedagógica de ensino desse município no seu dia a dia, aplicada nas turmas que leciona na escola em que se encontra lotado? A sistematização das respostas dos professores, colocaremos na tabela a seguir:

Tabela 07: Introdução da Proposta Pedagógica de Ensino do Município de Aquiraz

\begin{tabular}{|l|l|l|l|}
\hline Categoria & Professores & $\begin{array}{l}\text { No de } \\
\text { respostas }\end{array}$ & $\%$ \\
\hline $\begin{array}{l}\text { Teve dificuldade, mas posteriormente } \\
\text { foi aceita }\end{array}$ & $\mathrm{P}_{03,} \mathrm{P}_{05} ; \mathrm{P}_{06} ;$ & 05 & $41,66 \%$ \\
\hline $\begin{array}{l}\mathrm{P}_{07} ; \mathrm{P}_{09} \\
\text { andamento das aulas }\end{array}$ & $\mathrm{P}_{02} ; \mathrm{P}_{04} ;$ & 02 & $16,66 \%$ \\
\hline $\begin{array}{l}\text { O ensino dos alunos se tornou mais } \\
\text { interessantes, pelo fato do ensino não }\end{array}$ & $\mathrm{P}_{11}$ & 01 & $8,33 \%$ \\
\hline $\begin{array}{l}\text { estar centrado na prática } \\
\text { Considera que não foi introduzida }\end{array}$ & $\mathrm{P}_{01} ; \mathrm{P}_{08}$ & 02 & $16,66 \%$ \\
\hline $\begin{array}{l}\text { Não opinou apenas observou, pois, } \\
\text { iniciou no ano em curso nesse } \\
\text { município }\end{array}$ & $\mathrm{P}_{10} ; \mathrm{P}_{12}$ & 02 & $16,66 \%$ \\
\hline
\end{tabular}

Fonte: ARAÚJO, M. V. de. Baseado na sistematização das respostas dos professores sujeitos da pesquisa

Como podemos constatar, na tabela 06, a maioria das respostas dadas pelos docentes, total de 05 , afirmaram que a proposta pedagógica, no início teve dificuldade de aceitação pela maioria dos professores, mas que depois, foi aceita plenamente, os 
demais, as respostas foram potencialmente igualitárias onde grupos de 02 professores opinaram e apenas 01 dos professores afirmou que o ensino dos alunos se tornou mais interessante pelo fato do ensino não estar centrada na pratica.

Vemos ainda na tabela que 02 professores não opinaram, disseram que entraram no município apenas no em curso, pouco tempo para constatar a eficiência ou não da proposta pedagógica, das formações e implantação de um currículo. Nas conversas trocadas na entrevista que tivemos com os sujeitos da pesquisa, percebemos que a proposta pedagógica facilita o andamento das aulas, isso por haver planejamento.

Os estudos realizados nas formações se tornaram mais interessantes, no início dessas tiveram dificuldades para aceitá-las, mas, depois as aceitaram plenamente sem nenhuma resistência, pois perceberam que só traziam referências a ser aplicadas nas didáticas pedagógicas aplicadas nas modalidades de ensino.

Nossas discussões sobre papel social da escola, nos levaram a entender que a escola necessita deixar de ser um local de implementação de decisões curriculares, pois essas são definidas por terceiros e sim, ela deve passar a ser o próprio local de construção do currículo, pensamento a esse respeito não é recente e vemos a fundamentação a respeito, nos estudos de Pacheco e Morgado (2002), segundo os autores:

As formas de exercer o controle sobre o currículo, da prescrição para sugestão é essencial. Porém, como isso acontece, quais as dificuldades encontradas e como superá-las pouco se tem registro (PACHECO e MORGADO, 2002, p. 24)

Analisando essa citação, vemos um contexto em que a construção do currículo deve ser realizada pelo próprio grupo de professores, só eles são capazes de verificar quais as reações e modificar a compreensão do currículo, o que ele gera dentro do contexto na modalidade de ensino que atuam.

Agora, ao discorrermos sobre o início da inserção do currículo, percebemos que ele significa mais do que a execução de uma lista de conteúdo, pois, ao construí-lo, ele 
foi discutido e planejado em conjunto por todos que compõe a instituição educacional e suas ações são pensadas para beneficiar o processo de ensino-aprendizagem.

Sendo assim, a introdução de um currículo contempla a avaliação dos saberes construídos na discussão dos envolvidos no processo de aprendizagem dos educandos e o que eles venham compreender com a didática aplicada em suas práticas docentes.

Portanto, a análise de tudo que percebemos durante a construção de nosso trabalho com a aplicação dos questionários, observação de sala de aula e entrevistas, vimos incertezas, duvidas, insegurança relatadas pelos professores sujeito da pesquisa, sendo eles, o currículo e as formações, estavam transformando seu modo de ensinar, o conteúdo a ser aplicado, e ao mesmo tempo em que promovem uma mudança no contexto que atuam.

Como discorremos anteriormente, usamos temas e categorias nos questionários aplicados e o último foi da Auto avaliação e avaliação do currículo, nessa categoria queríamos salientar a visão dos professores e como eles vêem a avaliação do currículo implantado no município de Aquiraz, assim indagamos: Você identifica e verifica alguma diferença em suas aulas com os alunos e na escola, após implantação do currículo?

A essa indagação sistematizamos as respostas dos doze professores sujeito da pesquisa e as colocaremos na tabela abaixo:

Tabela 08: Indagação sobre diferenças nas aulas após implantação do currículo no Município de Aquiraz

\begin{tabular}{|l|l|l|l|l|}
\hline Categoria & Professores & $\begin{array}{l}\text { No de } \\
\text { respostas }\end{array}$ & $\%$ \\
\hline $\begin{array}{l}\text { Sim, uma relação positiva tanto por } \\
\text { parte dos alunos como pelo } \\
\text { professorado. }\end{array}$ & $P_{03,} P_{05} ; P_{06} ;$ & 04 & $33,33 \%$ \\
\hline
\end{tabular}




\begin{tabular}{|l|l|l|l|}
\hline $\begin{array}{l}\text { Verificou uma aprendizagem } \\
\text { significativa por parte dos alunos }\end{array}$ & $\mathrm{P}_{02} ; \mathrm{P}_{04} ;$ & 02 & $16,66 \%$ \\
\hline $\begin{array}{l}\text { Não, nenhuma diferença } \\
\begin{array}{l}\text { Não consegue apontar diferenças pelo } \\
\text { pouco tempo de atuação }\end{array}\end{array}$ & $\mathrm{P}_{11}, \mathrm{P}_{01} ; \mathrm{P}_{08}$ & 03 & $25 \%$ \\
\hline $\begin{array}{l}\text { Não opinou apenas observou, pois, } \\
\text { iniciou no ano em curso nesse } \\
\text { município }\end{array}$ & $\mathrm{P}_{12}$ & 02 & $16,66 \%$ \\
\hline
\end{tabular}

Fonte: ARAÚJO, M. V. de. Baseado na sistematização das respostas dos professores sujeitos da pesquisa

Analisando o quadro com as respostas dadas pelos professores, vimos que as mais expressivas foram as de que houve mudanças por parte dos professores e dos alunos com a implantação de um currículo elaborado por todos que compõem o sistema educacional do município investigado, isso devido ao sistema estar mais organizado pelas áreas de conhecimentos, esta afirmação foi apontada por 06 professores, juntando os dois primeiros grupos.

Assim, constatamos que o currículo adotado possibilitou uma aprendizagem mais significativa por parte dos estudantes, mas, para que o professor venha promover uma transformação real dos discentes é necessário que antecipe e planeje o seu ensino, com a melhor maneira de se abordar o conteúdo a ser repassado. Esse pensamento fundamentamos na citação de MIZUKAMI (1986) que diz:

O professor deve criar condições para que, juntamente com os alunos, consciência ingênua seja superada e que estes possam perceber as contradições da sociedade e grupos em que vivem (MIZUKAMI, 1986, p. 99).

Percebemos na citação que o pensamento do autor é de que se conseguirmos ver as diferenças e as exemplificarmos teremos garantia de que mudanças positivas venham acontecer. 
Os demais professores, na junção dos três últimos grupos, alegaram não terem percebido nenhuma diferença na aplicação de suas didáticas pedagógicas com a implantação do currículo, porém, devemos registrar que as argumentações geradoras das respostas dos docentes são de causas diferentes, vejamos: os professores; 01 , 08, 09, 10, e 11, afirmaram que não notaram diferenças em suas atuações, por ensinarem em ordem "pratica".

Essa afirmação, de certo modo, estive presente nas respostas dos três últimos grupos, contudo, nossa análise é que fica demonstrado o não entendimento do que seria a proposta da formação continuada ministrada pelo grupo de professores da Secretaria de Educação do município de Aquiraz.

Portanto, esses grupos desconsideram o que recebem de informação nas formações recebidas, dizem não terem usufruído de nada, por não terem a instrução, estratégias definidas e prontas a serem aplicadas, do modo que eles informaram operarem na área "pratica" com seus alunos. Assim, buscamos a citação de IMBERNON (2010) que afirma exista, com atitudes como essa, necessidade de:

Se abandonar o conceito obsoleto de que a formação de professor é a atualização científica didática e psicopedagógico do professor para adotar um conceito de formação que consiste em descobrir, organizar, fundamentar, revisar e construir a teoria (IMBERNÓN, 2010, p. 51).

É pertinente afirmar que ao pensar sobre formação de professor significa ir além de ações concretas, é acima de tudo, mobilizar os conhecimentos sobre a docência em si, e todos os aspectos e conceitos que a envolve, é isso que vemos na afirmação acima.

Já na afirmação do professor 12 que não quis opinar pelo fato de ter entrado no município no ano em curso, esse afirmou na entrevista que começou a ministrar suas aulas com base na formação recebida e não tem como comparar as ações executadas antes e depois da implantação do currículo. 
Assim, concluímos a análise da aplicação dos ${ }^{21}$ questionários aos sujeitos da pesquisa e a sistematização das respostas obtidas e suas porcentagens.

\section{PEQUENA ANÁLISE DA FICHA DE OBSERVAÇÃO}

No início de nossa descrição sobre procedimentos metodológicos, narramos sobre as observações de sala de aula, para realizar essa etapa de nossa pesquisa, elaboramos uma ficha, essas nos orientariam na realização de nossa observação de sala de aula.

Assim, estabelecemos algumas considerações para a análise das observações das aulas, foram elas:

Quadro 34: Considerações da ficha de observação

\section{Realizar observações de aulas nas turmas dos sujeitos da pesquisa}

Considerar a finalidade do planejamento do professor

Observar a sequência de ensino do mesmo conteúdo

Identificar a relação com o processo de ensino-aprendizagem

Verificar a relação do conteúdo estabelecido pelo currículo municipal nas aulas ministradas pelos docentes observados

ARAÚJO, M. V. de. Baseado na elaboração da ficha de observação

Após traçarmos as considerações, construímos a tabela 09 descrevendo as ações arquitetadas nas aulas em que praticamos as observações, nela colocaremos a soma total dos professores sujeitos da pesquisa com os seus respectivos procedimentos na prática docente de sala de aula. Vejamos essa tabela: 
Tabela 09: Observação das Aulas dos Sujeitos da Pesquisa

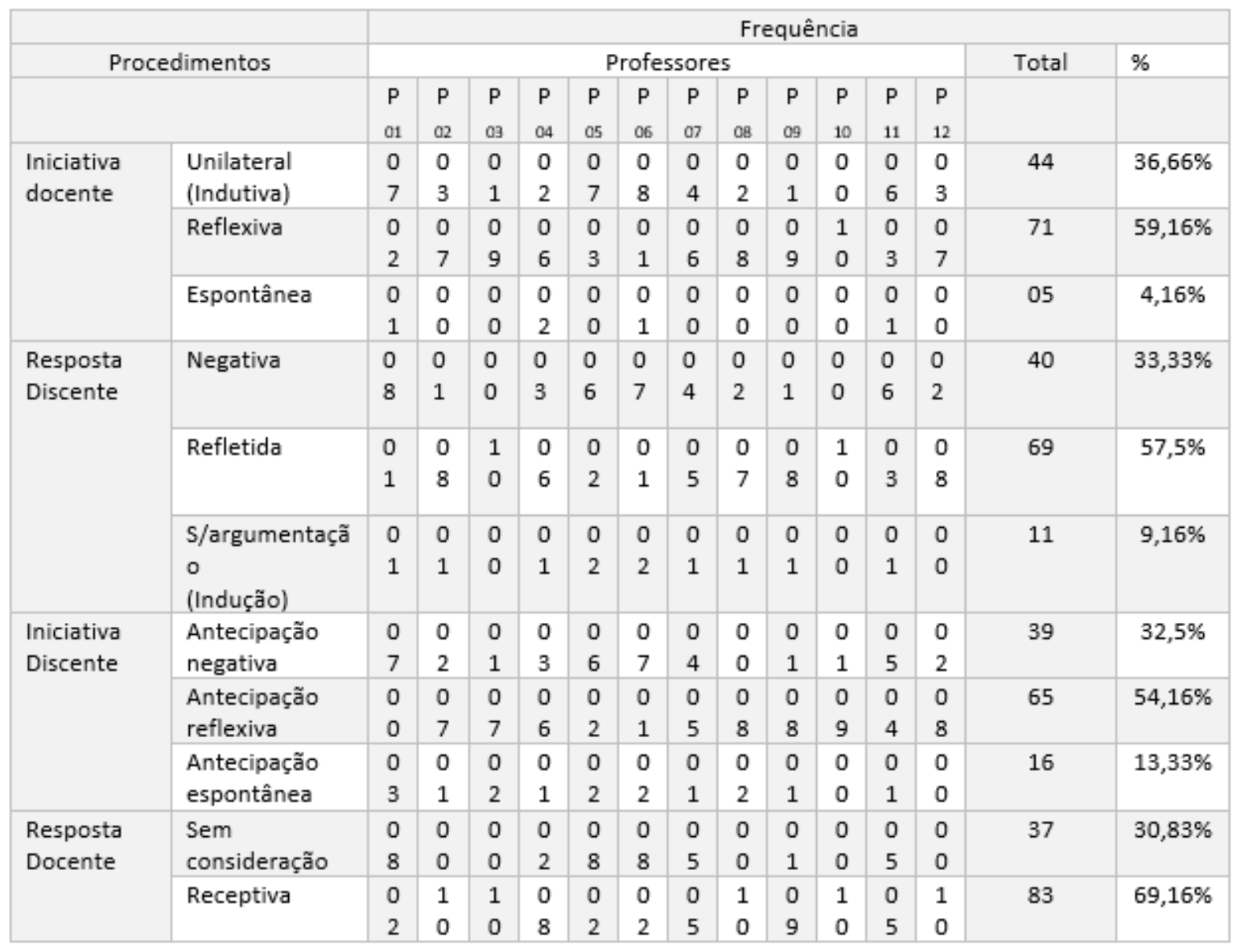

Fonte: ARAÚJO, M. V. de. Baseado na sistematização das observações dos professores sujeitos da pesquisa

Analisando a tabela acima colocada com as frequências dos procedimentos utilizados pelos professores observados, podemos averiguar a aproximação e o distanciamento entre eles, e assim, os dividir em três grupos:

Tabela 10: Análise dos Procedimentos dos Professores em suas aulas

\begin{tabular}{|l|l|l|l|}
\hline Procedimentos & Professores & Total & $\%$ \\
\hline Maior $\mathbf{n}^{\circ}$ de intervenções reflexivas & $\mathrm{P}_{02,} \mathrm{P}_{03}, \mathrm{P}_{08}, \mathrm{P}_{09}, \mathrm{P}_{10}$, & 06 & $50 \%$ \\
& $\mathrm{P}_{12}$ & & \\
\hline
\end{tabular}




\section{\begin{tabular}{|l|l|l|l} 
Em fase de transição ainda como & $P_{04}, P_{07}$ & 02 & $16,66 \%$
\end{tabular} unilateral \\ Maior ação unilateral \\ $P_{01}, P_{05}, P_{06}, P_{11}$ \\ 04 \\ $33,33 \%$}

Fonte: ARAÚJO, M. V. de. Análise das ações dos professores durante as observações (2016).

A sistematização de nossa observação nos leva a constatação que $50 \%$ dos professores tem procedimento de ações reflexivas em suas aulas, tanto em sua docência como nas respostas dos discentes, observamos ainda que $16,66 \%$ desses, estão em fase de transição para a mesma ação e que 33,33\% continuam em ações unilaterais, ou seja, adotam aulas tradicionais onde os alunos não se envolvem nas aulas ministradas por esses professores.

É satisfatório vermos que a ação reflexiva dar um somatório de 50\% e que esse grupo de professores está prestes a aumentar por contar com 16,66\% em transição, o que demonstra que houve tentativas de promover neles uma participação ativa nas aulas por parte do primeiro grupo, assim, a partir de suas intervenções podem desencadear em seus alunos ações correspondentes e qualificadas para a aprendizagem total deles.

A constatação de transformações por parte dos professores sujeitos de nossa pesquisa é considerável, percebemos que suas participações nas formações oferecidas pelo município, aos poucos, estão dando a esses, uma visão de didáticas transformadoras a serem aplicadas em suas aulas, e assim, os educandos possam se envolver plenamente no processo de ensino-aprendizagem.

Notório é que os professores estão em um processo de mudança devido o panorama geral demonstrar que as ações no coletivo já são superiores a uma tendência educacional reflexiva e transformadora procurando a todo momento uma resposta dos discentes e que esta seja plenamente argumentativa.

Louvamos o esforço do município de Aquiraz no que se refere a ministrar uma educação igualitária e qualificada envolvendo todos que fazem parte da educação. 


\section{ANÁLISE DA ENTREVISTA}

A entrevista como discorremos anteriormente foi o terceiro elemento utilizado como metodologia de nossa pesquisa, a estruturamos pelo método do "grupo focal", ou seja, entrevistamos 12 professores escolhidos a serem: observados, entrevistados e responderem questionários.

Assim, estruturamos um protocolo com temas e objetivos pré-estabelecidos que serviriam de orientação as perguntas que realizaríamos, e, posteriormente faríamos uma análise das respostas e as sistematizaríamos em tabelas. Utilizamos os mesmos temas utilizados na aplicação dos questionários com perguntas diferentes. Relembrando, os temas foram:

- a) Fases da carreira docente;

- b) Conhecimentos sobre a construção do currículo;

- c) Auto avaliação e avaliação do currículo.

Partindo para o primeiro tema, nossa primeira pergunta se relacionava à formação individual dos professores e as fases da carreira docente. Indagamos: Você recorda de algum professor, ou de um contexto escolar/familiar que o motivou a escolher sua profissão de docente?

Verificamos pequenas semelhanças nas histórias narradas pelos professores, mesmo não tendo eles citado um fator que os tenham influenciado na decisão de escolher a profissão de professor, foram unânimes quando referenciaram as aulas recebidas, com vivencias, em sua maioria, eram aulas espontâneas, descaracterizadas como área de conhecimento.

Contudo, disseram que suas aulas hoje não são iguais às que tiveram em sua formação. Sistematizamos suas respostas conforme mostrada na tabela a seguir: 
Tabela 11: Fatores para a Escolha Profissional de Docência

\begin{tabular}{|c|c|c|c|}
\hline Categoria & Professores & $\begin{array}{l}\text { № de } \\
\text { respostas }\end{array}$ & $\%$ \\
\hline $\begin{array}{l}\text { Trajetória de seus Estudos e } \\
\text { identificação com a docência }\end{array}$ & $\begin{array}{l}\mathrm{P}_{03} ; \mathrm{P}_{05} ; \mathrm{P}_{06} ; \mathrm{P}_{09} \\
\mathrm{P}_{10}\end{array}$ & 05 & $41,66 \%$ \\
\hline $\begin{array}{l}\text { Identificação por um professor de } \\
\text { uma disciplina na faculdade }\end{array}$ & $\mathrm{P}_{04} ; \mathrm{P}_{07}$ & 02 & $16,66 \%$ \\
\hline $\begin{array}{l}\text { Satisfação de trabalhar com } \\
\text { crianças da educação infantil }\end{array}$ & $P_{02,} P_{08}, P_{12}$ & 03 & $25 \%$ \\
\hline $\begin{array}{l}\text { Encontrou facilidade para entrar na } \\
\text { profissão }\end{array}$ & $\mathrm{P}_{01} ; \mathrm{P}_{11}$ & 02 & $16,66 \%$ \\
\hline
\end{tabular}

Fonte: ARAÚJO, M. V. de. Baseado na sistematização das respostas dos professores sujeitos da pesquisa

Analisando as respostas podemos identificar um grupo maior com uma identificação para a docência, os demais grupos a outros fatores, na entrevistaram citaram também razoes para a motivação de escolha ao magistério como; experiências previas na adolescência, vivencias familiares, entre outros, assim, refletimos, os motivos que levam os sujeitos escolherem uma profissão são de fontes diversas e singulares.

Esse pensamento fundamentamos na citação de Borges e Desbiens (2005) que citam: "Algumas vezes ocorrem desvios, relacionados há certas circunstâncias de vida, que determinam ou influenciam o sujeito durante seu percurso" (BORGES; DESBIENS 2005, p. 171).

Em relação ao primeiro tema fizemos ainda outra pergunta: $O$ docente que atua há muito tempo na escola, possui conhecimentos diferenciados de um recém-formado?

As respostas dadas pelos professores foram sistematizadas da seguinte maneira por compreendermos que a carreira profissional do professor é configurada por várias 
etapas formativas, que em cada momento são priorizadas algumas formas de aprendizagem, vinculada de certa forma ao seu ensino.

Tabela 12: Conhecimentos Diferenciados pelo Tempo de Estar na Escola

\begin{tabular}{|l|l|l|l|}
\hline Categoria & Professores & $\begin{array}{l}\text { No } \\
\text { respostas }\end{array}$ & $\%$ \\
\hline $\begin{array}{l}\text { Vivenciar o contexto estrutural, } \\
\text { administrativo da escola e as diferentes } \\
\text { realidades e como agir com essa } \\
\text { diversidade }\end{array}$ & $\mathrm{P}_{05} \mathrm{P}_{10} \mathrm{P}_{11}$ & 04 & $33,33 \%$ \\
\hline $\begin{array}{l}\text { Verificar a aprendizagem prolongada } \\
\text { dos alunos }\end{array}$ & $\mathrm{P}_{01} ; \mathrm{P}_{06}$ & 02 & \\
\hline $\begin{array}{l}\text { Melhorar a adequação das estratégias ao } \\
\text { ensino-aprendizagem }\end{array}$ & $\mathrm{P}_{02}, \mathrm{P}_{08}$, & 02 & $16,66 \%$ \\
\hline $\begin{array}{l}\text { Verificar na ação de outros professores } \\
\text { a ação diferente da sua }\end{array}$ & $\mathrm{P}_{03} ; \mathrm{P}_{11}$ & 02 & $16,66 \%$ \\
\hline $\begin{array}{l}\text { Conhecer melhor os aspectos da } \\
\text { profissão, direitos e poderes }\end{array}$ & $\mathrm{P}_{04} ; \mathrm{P}_{09}$ & 02 & $16,66 \%$ \\
\hline
\end{tabular}

Fonte: ARAÚJO, M. V. de. Baseado na sistematização das respostas dos professores sujeitos da pesquisa

Analisando as respostas colocadas na tabela acima, verificamos na maioria a consciência de que ficar a mais tempo em um estabelecimento de ensino favorece ao conhecimento estruturais, administrativo e aprendizagem prolongada dos alunos. $\mathrm{Na}$ citação de Porlán (1997 apud, Leme 2006, p. 27) uma fundamentação de que o conhecimento se aprofunda à medida que a prática se alonga. Segundo o autor:

“[...] há conhecimentos que são produzidos por meio da prática profissional, são saberes de natureza e conteúdos variados, porém, se justapõem no pensamento prático do professor" (PORLÁN, 1997 apud, LEME 2006, p.27). 
A citação do autor destaca o conhecimento sobre o contexto educativo e o conhecimento sobre os alunos e suas características, assim, a prática quando mais durável mais conhecimentos são adquiridos.

No segundo tema abordaremos os Conhecimentos sobre a construção do currículo, consideramos que no momento da construção de um currículo é inerente conhecer as teorias educacionais, e por meio desses estudos, devemos determinar uma delas para orientação e consciência de visão de mundo, da sociedade, da educação, de ensino e aprendizagem, entre outros fatores que compõem.

Após a escolha do modelo curricular em que os conceitos estão diretamente ligados à teoria educacional, a visão dele deverá ser disseminada aos professores que discutirão, construirão e implementarão o currículo, assim, questionamos aos professores: Vocês concordam com a teoria educacional constituída para orientar o currículo adotado no município? Sistematizamos as respostas e as colocamos na tabela abaixo:

Tabela 13: Concordância dos Professores com a teoria educacional escolhida para orientar o currículo

\begin{tabular}{|l|l|l|l|}
\hline Categoria & Professores & $\begin{array}{l}\text { No de } \\
\text { respostas }\end{array}$ & $\%$ \\
\hline $\begin{array}{l}\text { Considera que a construção do } \\
\text { currículo não foi imposta }\end{array}$ & $\mathrm{P}_{05} ; \mathrm{P}_{07} ;$ & 02 & $16,66 \%$ \\
\hline $\begin{array}{l}\text { Afirma que é imposto a implementação } \\
\text { do currículo }\end{array}$ & $\mathrm{P}_{01} ; \mathrm{P}_{06}$ & 02 & $16,66 \%$ \\
\hline $\begin{array}{l}\text { Apresenta } \\
\text { epistemológica uma confusão }\end{array}$ & $\mathrm{P}_{02}, \mathrm{P}_{08}, \mathrm{P}_{11}$, & 04 & $33,33 \%$ \\
\hline $\begin{array}{l}\text { Consideram que a elaboração do } \\
\text { currículo proporcionou uma construção } \\
\text { de conhecimento e saberes }\end{array}$ & $\mathrm{P}_{03} ; \mathrm{P}_{10}$, & $\mathrm{P}_{09}$, & 04 \\
\hline
\end{tabular}


Fonte: ARAÚJO, M. V. de. Baseado na sistematização das respostas dos professores sujeitos da pesquisa

Analisando a tabela e as respostas dos professores a entrevista prontamente gravada, constatamos que inicialmente eles se pronunciaram dizendo que o currículo foi estruturado no processo de construção coletiva por meio de discussões por todos os grupos que fazem parte da educação do município. Todavia os professores: $\mathrm{P}_{01}$; $\mathrm{P}_{06}$ disseram que o currículo foi imposto contradizendo a afirmativa da maioria dos colegas, pelo motivo, segundo eles, ter sido colocado como obrigatório para a rede municipal de educação do município.

Apesar das respostas mostrarem pequenas diferenças, é inerente dizermos que os princípios das teorias devem estar em constantes estudos, nesse sentido notamos uma unanimidade nas falas dos professores ao considerarem que a elaboração do currículo proporcionou uma construção de conhecimento e saberes.

Continuamos abordando a construção do currículo verificando quais conhecimentos foram construídos durante o processo de estruturação, construção e implementação do currículo. Indagamos: Algum conhecimento foi construído durante a elaboração do currículo? Qual (is) poderia(m) ser destacado(s)?

Tabela 14: Construção do Conhecimento na Elaboração do Currículo

\begin{tabular}{|l|l|l|l|}
\hline Categoria & Professores & $\begin{array}{l}\text { No } \\
\text { respostas }\end{array}$ & $\%$ \\
\hline $\begin{array}{l}\text { Concordam que houve a construção } \\
\text { do conhecimento e saberes }\end{array}$ & $\mathrm{P}_{03} ; \mathrm{P}_{04} \mathrm{P}_{09}$, & 04 & $33,33 \%$ \\
\hline $\begin{array}{l}\text { Sentem necessidade de estudar, } \\
\text { pesquisar, conhecer as formas }\end{array}$ & $\mathrm{P}_{01} ; \mathrm{P}_{06}$ & 02 & $16,66 \%$ \\
\hline $\begin{array}{l}\text { Sim o conhecimento do movimento } \\
\text { humano e corporal }\end{array}$ & $\mathrm{P}_{02,} \mathrm{P}_{08}, \mathrm{P}_{11}$, & 03 & $25 \%$ \\
\hline $\begin{array}{l}\text { O conhecimento da organização do } \\
\text { ensino aos educandos }\end{array}$ &, $\mathrm{P}_{05} ; \mathrm{P}_{07} ; \mathrm{P}_{12}$, & 03 & $25 \%$ \\
\hline
\end{tabular}


Fonte: ARAÚJO, M. V. de. Baseado na sistematização das respostas dos professores sujeitos da pesquisa

Vemos nas respostas dadas pelos professores que houve aquisição de conhecimento e esses foram significativos para melhoria profissional, desse modo, salientamos que construir um currículo requer dos professores a mobilização de todos os conhecimentos profissionais.

Sendo assim, devemos sistematizar o que de fato está presente em sua realidade, todavia se faz necessário o auxílio de conhecimentos científicos, e neste intuito, a formação continuada tem a capacidade de promover conhecimentos aos docentes.

Dessa forma, todos os professores testemunharam que houve uma construção significativa de conhecimento, da mesma maneira também, os docentes afirmaram que conseguiram verificar a necessidade de pesquisar, de estudar e se atualizar para haver qualidade das didáticas pedagógicas aplicadas.

Por tudo que discorremos sobre construção de currículo, além da sistematização das respostas dos docentes, entendemos que a situação de elaboração desse, deve ser colocado constantemente para discussão nas formações de professores para que eles analisem os reais objetivos constitutivos do projeto proposto pelo município.

Não devemos esquecer que o currículo deve ter relação real, ao mesmo tempo, oculto e oficial, estar plenamente vinculado ao processo educativo, sendo um único norteador da finalidade qualificada de ensino escolar.

Chegamos a última temática que utilizamos em nossa entrevista: Auto avaliação e avaliação do currículo, esta, vinculada aos tipos de avaliação que compreendemos estarem intrinsecamente interligadas; a avaliação pessoal da atuação do professor e a avaliação do currículo, em contexto geral, sem entrar nesse momento, conteúdo específico.

Por estarmos na etapa de conclusão da entrevista, indagamos aos sujeitos da pesquisa: Ao presenciarmos as reuniões da discussão de elaboração do currículo, 
verificamos que houve divergências quanto à quantidade de conteúdo e sua sequência, assim perguntamos, como isso interfere em suas aulas? Que valor atribui às sugestões dos colegas?

Tabela 15: Considerações das Opiniões sobre Currículo, divergências e conteúdo

\begin{tabular}{|l|l|l|l|}
\hline Categoria & Professores & $\begin{array}{l}\text { No de } \\
\text { respostas }\end{array}$ & \\
\hline $\begin{array}{l}\text { Identificou que o trabalho realizado } \\
\text { pelo grupo trouxe vários benefícios }\end{array}$ & $\mathrm{P}_{03}, \mathrm{P}_{04}, \mathrm{P}_{09}$, & 04 & $33,33 \%$ \\
\hline $\begin{array}{l}\text { Verificou que o currículo traz muito } \\
\text { conteúdo e que ainda está confuso }\end{array}$ & $\mathrm{P}_{01}, \mathrm{P}_{06}, \mathrm{P}_{05}$, & 04 & $33,33 \%$ \\
\hline $\begin{array}{l}\text { Considera as opiniões dos } \\
\text { professores como relevante }\end{array}$ & $\mathrm{P}_{02}, \mathrm{P}_{08,}, \mathrm{P}_{11}$, & 04 & $33,33 \%$ \\
\hline
\end{tabular}

Fonte: ARAÚJO, M. V. de. Baseado na sistematização das respostas dos professores Analisando as respostas na tabela acima, verificamos que há divergências de posicionamentos, mas, consideramos que diferenças de opiniões dentro de um grupo de estudo, são perfeitamente normais e aceitáveis. Porém é pertinente saber conviver com esses confrontos de ideias e os vincular aos seus conhecimentos e esse é um dos saberes que o professor possui e sabe discernir.

Constatamos assim que os professores entrevistados do grupo de estudo afirmaram que as diferenças trouxeram vários benefícios as suas práticas pedagógicas que conseguiram ter crescimento profissional durante o processo de estudo.

Mencionaram ainda que é importantíssimo manter discussão dentro do grupo envolvido no sistema educacional, mesmo havendo discordância entre os membros e que é possível pensar nas sugestões durante suas aulas, e até mesmo modificar seu modo de entender, sendo os resultados na maioria das vezes, positivo quando aplicado conteúdo discutido e colocado no currículo elaborado por todos. 
Percebemos que o principal ponto de divergência que apareceu nas discussões envolvia o elemento da quantidade de aulas, mas, o grupo chegou a uma conclusão em comum: concordaram que ainda há muito conteúdo e que esse poderia e deveria ser mais bem organizado para ser ministrado.

Portanto, concordaram que para elucidar a questão do conteúdo, realizariam reuniões para reformular o modo de apresentar o currículo, e quais os principais conteúdos que devem permanecer.

O que gerou essa relação entre a quantidade de conteúdo e número de aulas, se deu pelo relato do que seja a Interdisciplinaridade: Este princípio está expresso nas ações de alguns professores, e isso acarreta outro problema que também está ligado ao currículo. Abaixo colocamos a figura de um grupo de professores após o término de uma das formações ministrada em uma das escolas do município:

Figura 09: logomarca da Secretaria de Educação.

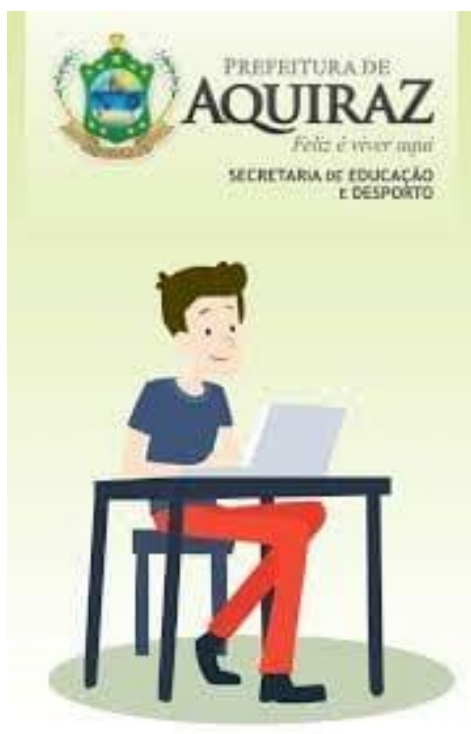

Fonte: ARAÚJO, M. V. de. Tirada do site da Secretaria de Educação 
Figura 10: grupo de professores após uma formação em uma das escolas do município

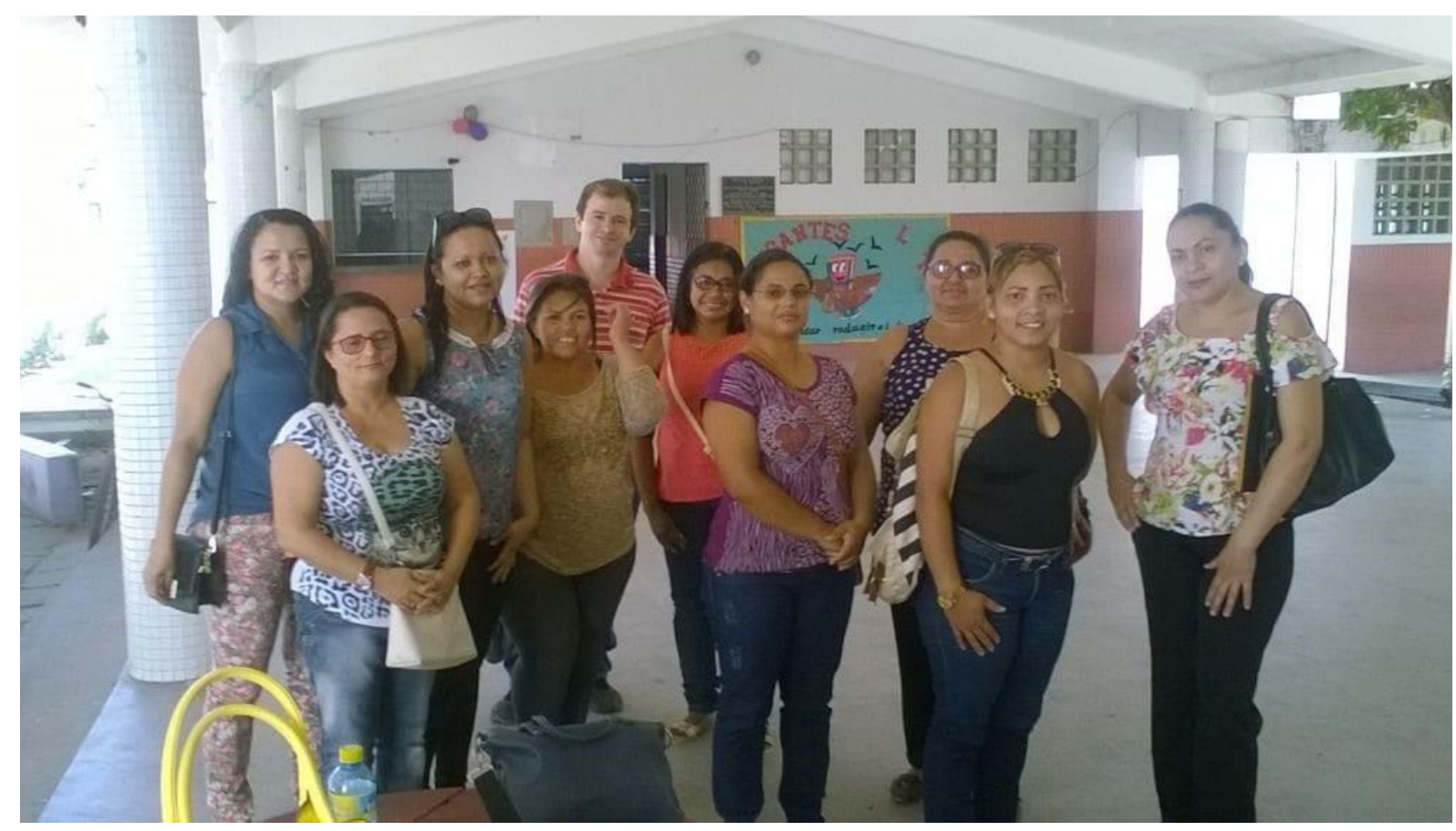

Fonte: ARAÚJO, M. V. de. Registro do Pesquisador

Nas formações que participamos com o consentimento da Secretaria de Educação, presenciamos discussões sobre planejamento das aulas dos professores, e a conscientização para que eles necessitam estar convictos de seus objetivos e escolha do conteúdo para não correr o risco de perder o foco de aprendizagem dos educandos, pois, ele deve ser relacionado em contexto nas aulas ministradas.

Durante a realização das etapas de nosso trabalho, vimos uma abertura do grupo de pesquisa para o diálogo, os professores tentam compreender o que é repassado nas formações e com elas melhorarem suas didáticas pedagógicas seguindo o currículo discutido, elaborado e implementado.

Para concluir nossa entrevista com o grupo de estudo, antecipamos a eles nossa última questão. O grupo se reuniu e dialogou sobre as dificuldades encontradas no processo de ensino e aprendizagem e ao retomarmos a entrevista, indagamos: A 
partir de suas aulas, você tem sugestão sobre algum tema para ser abordado pelo grupo? Os professores deram as sugestões colocadas na tabela a seguir:

Tabela 16: Sugestões de temas para estudo na formação de professor

\begin{tabular}{|l|l|l|l|}
\hline Categoria & Professores & $\begin{array}{l}\text { No } \\
\text { respostas }\end{array}$ & $\%$ \\
\hline $\begin{array}{l}\text { Estudar a Interdisciplinaridade e dos } \\
\text { temas transversais, cooperativismo }\end{array}$ & $\mathrm{P}_{03,} \mathrm{P}_{04}$ & 02 & $16,66 \%$ \\
\hline $\begin{array}{l}\text { Estudar mais sobre a avaliação } \\
\text { Organização do currículo pelo mapa } \\
\text { conceitual }\end{array}$ & $\mathrm{P}_{02}, \mathrm{P}_{08}$, & 02 & $16,66 \%$ \\
\hline $\begin{array}{l}\text { Divulgar os estudos do grupo, e o que se } \\
\text { tem feito }\end{array}$ & $\mathrm{P}_{05}, \mathrm{P}_{07}, \mathrm{P}_{12}$, & 03 & $16,66 \%$ \\
\hline $\begin{array}{l}\text { Organizar o currículo com os dias } \\
\text { letivos, estruturar os conteúdos com } \\
\text { margem de dias }\end{array}$ & $\mathrm{P}_{10,} \mathrm{P}_{09}$, & 02 & $25 \%$ \\
\hline $\begin{array}{l}\text { Troca de materiais e experiências de } \\
\text { ensino }\end{array}$ & $\mathrm{P}_{11}$ & 02 & $16,66 \%$ \\
\hline
\end{tabular}

Fonte: ARAÚJO, M. V. de. Baseado nas sugestões dos professores sujeitos da pesquisa

Ao concluirmos nossa entrevista, sistematizarmos as respostas registradas nos questionários e gravadas as respostas da entrevista e todas as anotações das observações de sala de aula, percebemos que o grupo de estudo não demonstrou receio de relatarem que ainda estão confusos e com dificuldades ao atuarem nas modalidades de ensino em que estão lotados no município de Aquiraz.

Mencionaram também que já identificaram sua necessidade de estudar mais sobre alguns saberes, e sugeriram que, no próximo encontro fosse tratado sobre: Interdisciplinaridade, cooperativismo e avaliação. Esses saberes, os professores 
alegaram serem fundamentais para sua intervenção profissional, uma vez que afeta diretamente o processo de ensino e aprendizagem.

Constatamos assim que, a relação do conteúdo pedagógico entre as diferentes disciplinas, requer que todos tenham consciência dos objetivos, o que cada matéria pretende repassar aos educandos, dessa forma, relataram o que cada docente irá contemplar em suas aulas na modalidade de ensino que atua.

É notório que o vínculo entre os conhecimentos ensinados aos alunos promove de acordo com as observações, a possibilidade de verificar o aumento da aprendizagem dos alunos, pela motivação e interação nos estudos traz vantagem para reconhecer que haverá interesse significativo em busca de crescimento cidadão.

\section{CONSIDERAÇÕES FINAIS}

Chegamos à etapa de conclusão de nosso estudo, nela estaremos discorrendo sobre os resultados desejados para o foco do objeto de pesquisa, formação de professor, currículo e práticas pedagógicas no município de Aquiraz.

Ao realizarmos o estudo sobre a formação continuada e o que a envolve dentro do processo de ensino e aprendizagem, consideramos elementos norteadores, entre eles a especificidade da disciplina no meio escolar, o contexto em que é realizado, a proposta do programa formador do município em estudo e o processo desencadeado com os conhecimentos abordados e construídos pelos grupos de professores.

Discorremos em nossa dissertação sobre temas de real importância para a educação e realizamos algumas indagações ao grupo escolhido como sujeito de pesquisa, esses responderam questionários, entrevistas e aceitaram nossa observação de sala de aula anteriormente estruturada, nesse sentido, indagamos temas como:

- Quais são os saberes e suas origens?

- De que forma os docentes se apropriam deles tornando-os conhecimentos?

- Como os articulam em suas práticas?

- Quais saberes são oriundos do próprio fazer docente, auto/reflexão? 
Para o tema em pesquisa, procuramos indicadores literários, encontramos vários estudos sobre este que utilizamos como literatura e os articulamos com os discursos dos professores escolhidos como sujeitos de nossa pesquisa.

Mostramos no decorrer de nosso trabalho os fatores que orientam a identidade docente que é constituída em um processo formativo profissional, esse se constrói desde sua vida enquanto aluno escolar, que foi definido como Pré-treino; depois, fase que gera as expectativas ao entrar no curso, chamada de Formação Inicial; a seguir, durante a graduação, nessa fase vem a intervenção por meio de estágio, denominado iniciação com os primeiros anos de exercício de sua profissão; e, por último, a formação permanente/continuada, considerado o docente como experiente por possuir mais de cinco anos de atuação como professor, essas fases foram especificamente detalhadas nos capítulos desse trabalho.

Nosso foco de investigação foi a Formação de Professor, mas, detalhamos o currículo, sua discussão, elaboração e implementação, detalhamos as práticas pedagógicas, tendências e abordagens educacionais e o projeto de formação de professor do município de Aquiraz.

Consideramos também que os conhecimentos transcendem as fases formativas de um docente, e se tornam um único conhecimento quando tem ação reflexiva frente a sua prática, na sua atuação profissional.

Certamente que em meio a ação se constrói o conhecimento tácito, esse construído frente a confronto, ao contexto, com a abstração de todos os demais saberes envolvidos no processo de ensino e aprendizagem que são: aprendizagem, currículo, avaliação entre outros, pois, o conhecimento da experiência não é mais um conhecimento do professor, mas sim, o resultado da união de todos os conhecimentos refletidos pela sua intervenção, sendo ele, individual e coletivo.

Quando refletimos e descrevemos sobre as questões que aparecem na formação e desenvolvimento do profissional de docência, destacamos duas grandes dimensões 
desse: profissionalização, essa com seus aspectos gerais da profissão e a profissionalidade com reflexão sobre sua especificidade ao ensino.

Entendemos que a formação de professor traça uma aliança entre a proposta de ensino e o currículo, assim a formação continuada é uma circunstância da construção, implementação e avaliação curricular.

Ao nosso ver, compreendemos que é a união de duas importantíssimas ações profissionais dos professores, uma vez que, possibilita a mobilização dos estudos pela análise de seu contexto, em junção com as produções atuais, ou seja, conhecimentos produzidos pelas pesquisas realizadas docentes.

Pertinentemente a formação atribui sentido e significado na aprendizagem do docente, ao mesmo tempo em que se altera o modo de ser/estar da educação na escola, (re) significando a concepção da área escolhida pelo professor perante os demais colegas, alunos e toda comunidade escolar. Falando do contexto histórico, esse demonstra como atendeu a diversos papeis no sistema educacional.

O papel histórico demostrado é devido à concepção que se tinha da área escolhida, tais como: historicidade, educacional, sociabilidade, espacial, entre outras. Ao refletirmos sobre esse ponto, nos vem questionamento: Quais os objetivos e finalidades da escola em nosso país? Por que os currículos escolares ainda mantem a margem algumas áreas a margem do processo educativo?

As questões levantadas, com certeza, motivam o sistema educacional à adoção de entendimento, nas posturas e atitudes equivocadas pelos gestores e professores das áreas de ensino, como por exemplo, a retirada de alunos das aulas por não cumprirem tarefas de outra disciplina como forma de punição, fato que não levará a aprendizagem ao aluno retirado.

Um dos Documentos Oficiais que trata da Educação brasileira é a LDBEN (93/94/94), esse documento foi utilizado em nossa pesquisa como referência literária, ele assegura a área das disciplinas como componente curricular, e, deve estar vinculada a todas as disciplinas. 
Sendo assim, é que se torna necessário conteúdo específico de cada disciplina a ser ensinado, mas, esses requerem pesquisas, análises sobre a discussão, construção, implantação e avaliação do currículo adotado nas instituições educacionais. Ao mesmo tempo em que contempla os estudos sobre as teorias curriculares, em que, a concepção de ensino aprendizagem deva estar em concordância com a teoria educacional assumida pelo docente.

A grande complexidade da problemática levantada em nosso estudo seria a aceitação do projeto da Secretaria de Educação de Aquiraz das formações de professores e a elaboração de um currículo unificado a ser utilizado nas instituições de ensino do citado município.

Para metodologia da pesquisa do objeto e da problemática levantada utilizamos diferentes procedimentos, sendo eles: entrega de questionários ao grupo de 12 professores escolhidos como sujeitos da pesquisa, observação de 10 aulas desses professores e entrevista previamente estruturada e marcada com o grupo de estudo realizada em uma das formações onde houve a participação do pesquisador. As perguntas foram articuladas e suas respectivas respostas sistematizadas.

As perguntas foram respectivamente selecionadas em quatro categorias e assim, facilitou a análise geral das respostas dos professores mostradas em tabelas, nelas verificamos aspectos iguais e diferentes nos dados dos três meios de coleta mencionados.

Como mencionamos as categorias estipuladas para os três instrumentos de coleta que serviram para fundamentação da parte principal dessa pesquisa e manter uma organização e facilidade de sistematização das respostas do grupo de pesquisa. As categorias foram:

- Carreira docente, com dados pessoais e profissionais;

- Conhecimentos sobre a construção do currículo;

- Desenvolvimento curricular (implantação);

- Auto avaliação e avaliação do currículo. 
Sabemos que ser professor implica em se tornar professor, ao mesmo tempo ter o direito de ensinar e possuir responsabilidade de entender a profissão docente como um processo que ocorre a cada momento, sendo assim, necessita de realizar constantemente reflexões críticas sobre sua própria atuação.

Pertinente que o docente seja processual e contínuo ao longo de sua vida, a isso denominamos de carreira docente, o processo de construção permanente de identidade profissional é necessário para a prática didática. A carreira docente, dos participantes foi investigada por meio da coleta de alguns dados como:

- Pessoais;

- Profissionais;

- Os meios de continuidade em seus estudos.

Em relação as respostas dadas pelo grupo de pesquisa aos procedimentos aplicados, sendo eles: questionários, entrevistas e observação em sala de aula, encontramos como respostas:

- Idade e tempo de carreira dos professores foram bem diversificados tendo idade de 51 com 27 anos de profissão e 31 anos com apenas dois anos de docência;

- Formações com e sem especialização.

Podemos inferir que tiveram uma graduação diferente, pela análise das propostas de mudanças, que modificaram os currículos de formação de professores das instituições superiores. Compreendendo a formação docente sendo muito além da formação inicial.

Percebemos no grupo de estudo uma abertura aos novos saberes, ficou evidente esse fato pelo modo como descreveram suas diferentes trajetórias históricas, cada docente, a princípio, apresentou um conjunto de objetivos ao escolher a profissão de docente, com modalidades de ensino diferenciada. Mesmo desvinculado do tempo de atuação, podemos verificar também nas observações uma diferença grande na ação docente. 
O município de Aquiraz promove uma grande rotatividade de professores nas 43 escolas existentes nesse, a tabela elaborada com o quadro de professores, sua idade, carreira e tempo de atuação no município, mostrou professores que entraram recentemente sendo necessária uma maior atenção a eles, os mais veteranos sugeriram uma revisão a cada início de ano, nas reuniões do grupo de estudos, de tudo o que foi construído até aquele momento, e deixar explícito a situação de que todos têm o direito a analisar e sugerir, sendo por meio da avaliação.

Acreditamos que a auto avaliação é o elemento mais essencial para uma formação continuada da carreira docente, nela os conhecimentos são construídos pela reflexão da experiência profissional com um contexto a ser constituído, dos conflitos a realidade, e, a partir de suas abstrações, sempre contando com um embasamento científico.

Descrevemos que a introdução dos conhecimentos nas instituições formadoras possibilitaria uma superação ao que os docentes na entrevista expressaram em forma de crítica sobre as formações acadêmicas que receberam e que esses discursos acadêmicos estão longe da verdadeira realidade do contexto que encontram nas escolas ao atuarem como docentes.

Os entrevistados ressaltaram também que a teoria é bem diferente da prática, os centros formadores são compostos por um verbalismo, e o contexto escolar por um ativismo.

Tratando teoria e prática como pólos opostos, não compreende os conhecimentos como interligados e não consegue pensar a atuação sem essas disjunções.

Ao realizarmos as observações, verificamos o relacionamento do currículo com o planejamento das aulas na escolha do conteúdo a ser aplicado. Foi possível também, constatar que a maioria dos professores do grupo de pesquisa aplicam aulas reflexivas com participação ativa dos discentes, mas, infelizmente observamos que tem ainda professores com didáticas tradicionais. 
Já na Entrevista notamos nos discursos dos professores um reconhecimento de que a construção e o desenvolvimento do currículo também os auxiliou na mudança de concepção do papel de suas aulas na escola que se tornaram mais significativas aos alunos e acima de tudo, contribuíram no relacionamento pessoal com todos que fazem parte da escola.

Quando os professores responderam sobre o desenvolvimento curricular consideraram que estão vinculados e estruturados para que haja um desenvolvimento do professor, e vice-versa, pois, o currículo transfere as ideias em práticas de sala de aula e ao mesmo tempo reforça a própria prática, testando de modo sistemático e consciente suas ideias.

Nos questionários, outro procedimento de nossa pesquisa, os professores demonstraram satisfação na construção do currículo municipal, pelo menos a maioria, isso porque participaram normalmente dos debates e das avaliações desse currículo utilizado em todas as instituições educacionais do município.

Houve também um número relevante de professores que disseram que sentiram dificuldades na implementação de seus planejamentos, mas, que conseguiram superar essas posteriormente. Talvez isso tenha acontecido pela troca de experiências no grupo de estudos pelas reuniões mensais, aos estudos realizados e ao apoio da Secretaria de Educação que sempre esteve presente em conflitos contrários à sua realização.

$\mathrm{Na}$ entrevista, houve uma discordância da autonomia em desenvolver o currículo, porém, isso foi gerado por uma má compreensão sobre o que se entende por currículo, e diante da própria discussão chegaram à conclusão de que existe a autonomia, porém, não de ações isoladas, mas, discutida e refletida em grupo.

Compreendemos que auto avaliação e avaliação do currículo se unem no momento de pensar sobre a atuação docente, isso reflete na prática docente, e também analisa a avaliação da proposta de ensino contida no currículo proposto pelo município. Essa afirmação pode ser evidenciada em todas as análises anteriores, em que o docente 
avalia o percurso formativo, a construção inicial do currículo, de como foi à implementação e como está sendo o desenvolvimento, ou seja, em todas as circunstâncias os princípios avaliativos são evidenciados.

Vimos nas respostas dos professores aos questionários muitos pontos positivos, das repercussões que tiveram em seus ensinos e na construção do currículo, em que os alunos têm uma aprendizagem significativa, e que, os demais professores, reconhecem um pouco mais a área como possuidora de conhecimento.

Nos planejamentos dos professores podemos notar um maior número de ações reflexivas, tanto nas respostas como nas antecipações discentes, o que ao nosso entender evidencia que conseguem contextualizar os conteúdos aprendidos, porque prolongam a aprendizagem das aulas, trazendo informações preciosas de sua realidade.

Averiguamos por meio do contexto de discordância dos professores quanto ao número de aulas para o ensino de cada conteúdo, como compartilhavam seus conhecimentos e se estes eram relevantes, e se chegariam a modificar suas atuações, alguns professores mencionaram isso durante a entrevista.

Verificamos, por meio das respostas sobre as sugestões de estudos, as dificuldades encontradas pelos professores, além de identificar o que eles pensavam ser inerentes a ação docente e que, ainda, não haviam sido abordados.

As respostas encontradas foram de cunho educativo geral, com a proposta de estudar sobre: interdisciplinaridade, avaliação, mapa conceitual, organização dos conteúdos, trocar mais experiências. Averiguamos que possuem dificuldades em argumentar a respeito de alguns temas importantes para a atuação docente.

Um dos assuntos que gerou instabilidade foi o conhecimento dos fins educativos, os propósitos da educação, valores e seus significados para a sociedade; há uma insegurança em falar sobre o papel da educação. 
Ao realizarmos a análise das respostas aos seres questionados se concordavam com a teoria educacional constituída no currículo, houve contradição nos discursos, ora afirmam que não possuíam nenhuma ao início de sua construção, ora teriam se apropriado de outra teoria proposta para as demais disciplinas da escola.

Refletindo sobre essa falta de posicionamento de alguns professores, constatamos que ela pode ser derivada do não entendimento das teorias educacionais, o que é preocupante, pois, no momento que não compreendem o paradigma que orienta suas ações elas passam a ser frágeis e inconsistentes.

Nas análises da sistematização das respostas percebemos que os conhecimentos construídos e mais mencionados pelo grupo de estudo foram os didáticos pedagógicos, o que de acordo com a literatura são conhecimentos que tiveram maior abordagem na formação inicial, o que podemos inferir tanto pelos discursos dos docentes, quanto pelas análises que pouco ou quase nada lhes foram ensinamos na graduação, tendo de ser construídos após, já enquanto atuavam.

Ressaltamos ainda que esses conhecimentos de origem da própria experiência docente foram citados pelos professores:

- Contexto educativo;

- Rotinas e guias das ações;

- Conhecimento dos alunos e das suas características.

Mas, podemos dizer que faltou aos professores assinalarem os conhecimentos de cunho científicos, conhecimento dos conteúdos, dos fins e dos propósitos educativos, e da própria construção e implementação do conhecimento curricular e suas teorias, em suma, o início do estudo desses conhecimentos em sua maioria é na formação inicial, porém, irá se prolongar por toda a carreira docente.

Entre um dos conhecimentos que o professor constrói durante as experiências é a capacidade de relacionar os conhecimentos acadêmicos como conteúdo de ensino, fator relevante ao adotar uma metodologia adequada a cada contexto, faixa etária e objetivo estabelecido. 
Sabemos que deve haver interação dos conhecimentos das diferentes fases de formação do docente, a autonomia é que o orienta, ao lidar em diferentes situações, desde o planejamento até a própria intervenção em sala de aula, com a adequação dos conteúdos, estipulando o término ou prolongamento das aulas de acordo com a aprendizagem, estratégias de ensino diferenciadas, percepção de análise das dificuldades encontradas. Ou seja, é preciso do ambiente real de aula para sua construção.

No entanto, o conhecimento tácito não deve ser provido de ações independentes, da análise superficial da realidade, no senso comum, na tentativa de erro e acerto, de forma inconsciente. Todo conhecimento é gerado intencionalmente, derivado de relações anteriores com estudos científicos.

As circunstâncias, onde quer que o professor esteja engajado nos estudos, pesquisa e reflexão sobre sua ação compreenderam que é produtor de conhecimento, bem como participante desse processo, com um papel essencial. Ao assumir esse papel o docente (re) significa o que sabe e para que deva saber.

Este agir, pensar de cada professor é conseguido de forma singular, visto que, empregam seus valores, suas concepções ao conteúdo ensinado, ao contexto, situação essa que não pode ser quantificada e transformada em apostilas, necessita do sujeito ativo no cotidiano escolar e sociocultural.

Ao compreender que a formação continuada como reflexão da realidade, e que esta deva promover nos professores a interação constante como seu contexto e com seu ensino, percebemos também, como fatos que desencadeiam a necessidade de constantemente reverem os conceitos, e as práticas didáticas, motivo que justifica que esse profissional necessita de continuas formações para assim melhorar seu ensinamento aos educandos.

A construção do currículo, implementação e a avaliação, é um dos meios mais interessantes para aliar todos esses fatores, e podemos afirmar que identificamos que os saberes dos professores são mobilizados de forma intensiva e extensiva, quando 
são promovidos a estudar e pesquisar sobre os temas educacionais, que talvez não fossem abordados senão tivessem um propósito, como foi à construção do currículo.

Afirmamos que existe a construção de conhecimentos, e que os mesmos repercutem na ação pedagógica do docente, e que isso não acontece de forma homogenia entre os participantes como demonstra as análises dos dados de nossa pesquisa mostrando resultados significativos da participação nas formações continuadas.

Descrevemos nos capítulos de nossa dissertação os assuntos envolvidos no sistema educacional e que os conhecimentos são produzidos a partir da realidade dos professores têm um valor, um sentido-significado muito maior para os docentes e, consequentemente, chances mais concretas de desencadearem nas suas práticas pedagógicas, visto que existem muitas resistências aos estudos, à mudança de entendimento, ao próprio modo de ministrar as aulas.

Outro fator favorecedor da construção do conhecimento é a união entre Secretaria de Educação e as escolas, o que colabora para promover a tomada de consciência do professor que deverão construir conhecimentos de naturezas diferenciadas, para o exercício de sua profissão, e que devem iniciar durante sua graduação e se perpetuar por toda carreira. Além de beneficiar a si próprios e os alunos, no processo de ensino aprendizagem, eles levam suas observações, suas experiências para a sala de aula.

Por fim, a necessidade de investigar a formação continuada de professores e como se constrói o conhecimento nessa etapa formativa profissional implica muito fatores variáveis, entre eles políticas públicas, a implementação dessa necessidade desde a formação inicial em promover no sujeito o entendimento de que sua formação é sempre seja inacabada.

Mostramos nessa pesquisa a real importância da formação de professor, implantação de currículo e a didática pedagógica para o desenvolvimento qualificado do processo de ensino e aprendizagem e que promover uma investigação no município de Aquiraz, só nos trouxe uma consciência reflexiva sobre docência, tendo essa uma necessidade de constantes renovações de estudo e pesquisas. 


\section{REFERENCIAS}

ALAIN (Émile Chartier) (1978): Reflexões sobre a educação. Trad. Maria Elisa Mascarenhas. SP, Saraiva

ALMEIDA, Jane. S. de, (1991). Formação de professores do 10 grau: a prática de ensino em questão. Mestrado em Educação. Universidade Federal de São Carlos

ALMEIDA, M. T. P. O Brincar na Educação Infantil. Revista Virtual EFArtigos. Natal/RN- volume 03- número 01- maio, 2005.

APPLE, M. Ideologia e Currículo. São Paulo: Brasiliense, 1982.

BASSO, S. I. O professor e o ensino: novos olhares. Cadernos CEDES, Campinas, n. 44, 1998.

BASTOS JLD, et al. Dental caries and associated factors among young male adults between 1999 and 2003 in Southern Brazil. Community Dent Health; 24: 122-127, 2007

AUSUBEL, David P.; NOVAK, Joseph. D. e HANESIAN, Helen. Psicologia educacional, Rio de Janeiro: Editora Interamericana, 2ª edição, 1980.

BORDENAVE, J. E. D. A opção pedagógica pode ter consequências individuais e sociais importantes. In: Revista de educação AEC, no 54, 1984, p. 41. 50.

BORGES, C.; DESBIENS, J.F. Saber, formar e intervir para uma educação física em mudança. Campinas, SP: Associados,2005.

BRASIL. Constituição (1988). Constituição da República Federativa do Brasil. Organização de Alexandre de Moraes. 16 Ed. São Paulo: Atlas. 2000.

BRASIL. Ministério da Educação Secretário de Educação Básica. Fundo Nacional de Desenvolvimento da Educação - FNDE Presidente do FNDE. Programa Nacional do Livro Didático. Brasília. 2007. 
BRASIL. Ministério da Educação e do Desporto. Conselho Nacional de Educação. Câmara de Educação Básica. Parecer CEB n. 4/98. Diretrizes Curriculares Nacionais para o Ensino Fundamental. Brasília, DF: MEC/CNE, 1998b.

BRASIL. Lei de Diretrizes e Bases da Educação Nacional. Lei número 9394, 20 de dezembro de 1996.

Diretrizes Curriculares Nacionais Gerais para a Educação Básica: PARECER CNE/CEB №:7/2010, 7 de abril de 2010, no Conselho Nacional da Educação, em Brasília, 2010. C.

Diretrizes Curriculares Nacionais Gerais para a Educação Básica: PARECER CNE/CEB №:7/2010, 13 de julho de 2010, no Conselho Nacional da Educação, em Brasília, 2010. D.

Diretrizes Curriculares Nacionais para a Formação de Professores em Educação Básica: Resolução CNE/CP n.ำ 01, de 18 de fevereiro de 2002, do Conselho Nacional da Educação, Brasília, 2002. A.

Diretrizes Curriculares Nacionais para a Formação de Professores em Educação Básica: Resolução CNE/CP n. 02 de 19 de fevereiro de 2002, do Conselho Nacional da Educação, Brasília, 2002. B.

Ministério da Educação. Indagações sobre currículo: Currículo e avaliação Brasília, MEC, 2007.

. Ministério da Educação. Lei n. 9.394, de 20 de dezembro de 1996a. Lei de Diretrizes e Bases da Educação Nacional. Disponível em: Acesso em: 04 ago. 2016. . Ministério da Educação. Parâmetros Curriculares Nacionais: temas transversais. Brasília, MEC,1998.

Conselho Federal de Educação. Resolução no 03, Brasília - DF, 1987 Conselho Nacional de Educação. Parecer CNE/CP 09, Brasília - DF, 2001 
. Parecer CNE/CP 138, Brasília-DF. 2002

Resolução CNE/CP 2, Brasília-DF, 2002

Resolução CNE/CP 7, Brasília-DF, 2004

Resolução CNE/CP 4, Brasília-DF, 2009

CESÁRIO, M. O currículo de formação de professores em educação física da universidade estadual de londrina: o projeto curricular e a prática pedagógica dos professores. Marilene Cesário - São Carlos, sp. Tese de doutorado, São Carlos: UFSCar, 2008. Capítulo II, O professor como formador e mediador no currículo: implicações para sua formação.

CHERVEL, A. História das disciplinas escolares: reflexões sobre um campo de pesquisa. Teoria e Educação, Porto Alegre, n2, p.177-229,1990.

DAY, G. Maintaining the Competitive Edge: Creating and Sustaining Advantages in Dynamic Competitive Environments. In: DAY, G.; REIBSTEIN, D.; GUNTHER, R. (Eds.). Wharton on Dynamic Competitive Strategy. New York: John Wiley \& Sons, 1997.

DELORS, Jacques. A educação para o século XXI: questões e perspectivas. Porto Alegre. Artmed. 2005.

DEMO, P. Educação pelo avesso: assistência como direito e como problema. São Paulo: Cortez, 2000.

DEMO, P. Conhecer e Aprender - Sabedoria dos Limites e Desafios. Artmed: Porto Alegre. 2000.

FORQUIN, J. Saberes escolares, imperativos didáticos e dinâmicas sociais. Teoria \& Educação, Porto Alegre, n. 5, p. 28-49, 1992. 
FREIRE, P. Pedagogia da autonomia: saberes necessários a prática educativa. São Paulo: Paz e Terra, 1996.

GARCIA, Carlos Marcelo. Os professores e sua formação. Lisboa: Dom Quixote, 1992.

GATTIJUNIOR, Décio. A História das Instituições Educacionais: inovações paradigmáticas e temáticas. In. José Carlos Soares, GATTIJUNIOR, Décio. Novos Temas em História da Educação Brasileira: Instituições Escolares e Educação na Imprensa. Campinas, SP. 2002.

GATTI, Bernadete Angelina. Implicações e perspectivas da pesquisa educacional no Brasil contemporâneo. Cadernos de Pesquisa da Fundação Carlos Chagas, São Paulo, SP, n. 113, p. 65-81, 2001.

GADOTTI, M. Boniteza de um sonho: ensinar-e-aprender com sentido. Curitiba: Positivo, 2005.

Pedagogia da Práxis. São Paulo: Cortez Editora; Instituto Paulo Freire, 1995.

GHEDIN, E.; Almeida, M. I.; LEITE, Y. U. F. Formação de professores: caminhos e descaminhos da prática. Brasília: Líber, 2008.

, Saberes, conhecimentos e as pedagogias das perguntas e das respostas: atualidade de antigos conflitos. Práxis educativa (UEPG-Online), v.4, p. 09-19, 2009.

GOODSON, I. F. Currículo: teoria e história. Trad. Attílio Brunetta. 3ª . Ed. Petrópolis: vozes, 1995.

HOFFMANN. J. Avaliação mitos e desafios: uma perspectiva construtivista. 40a․ Ed. Porto alegre: Mediação, 2010. 
IMBERNÓN, F. Formação docente e profissional: formar-se para a mudança e a incerteza. 8. ed. São Paulo: Cortez, 2010.

PIAGET, Jean. Teoria da aprendizagem na obra de Jean Piaget. São Paulo: UNESP, 2009

JULIA, D. A cultura escolar como objeto histórico. Revista brasileira da História da Educação. SBHE. Campinas: n.1. cap.1. p. 09-44, 2001.

KINCHELOE, J. L. A formação docente como compromisso político: mapeando o Pós-moderno. Porto Alegre: Artes Médicas, 1997.

LARROSA. J. Algunas notas sobre la experiência y sus linguajes. In: Trajetórias e perspectivas da formação de educadores/ LarroriR. L. B, org. SP: UNESP, 2004. p. $19-17834$.

LEME. T. N. Os conhecimentos práticos dos professores: (re)abrindo caminhos para a educação ambiental na escola. São Paulo: Annablume, 2006.

LIBANEO, J. C. Democratização da escola pública. A pedagogia crítico-social dos conteúdos. São Paulo: Loyola, 1985.

LIBÂNEO, J. C. Os significados da educação, modalidades de prática educativa e a organização do sistema educacional". Interação, Rev. da Faculdade de Educação/UFG, Goiânia, 16 (1-2), p.35-46, janeiro/dezembro. 1992.

LIBÂNEO, J.C. Fundamentos teóricos e práticos do trabalho docente - Estudo introdutório sobre Pedagogia e Didática. S. Paulo: PUC/SP, 1990.

LIMA, Telma Cristiane Sasso de; MIOTO, Regina Célia Tamaso. Procedimentos metodológicos na construção do conhecimento científico: a pesquisa bibliográfica. Revista Katalysis, v. 10, p. 35-45, 2007.

LOPES, A. C.; MACEDO, E. O Pensamento curricular no Brasil. In Currículo: debates contemporâneos. São Paulo: Cortez, 2002. 
LOVE, Joseph, Autonomia e Interdependência: São Paulo e a Federação Brasileira: 1889-1937, In: História Geral da Civilização brasileira. São Paulo: Difel, 1975, p.63.

MARRE, Jacques L. História de Vida e Método Biográfico. Cadernos de Sociologia. Porto Alegre, V.3, oㅜ 3, jan. /jul.1991

MOREIRA, A. F. B.; CANDAU, V. M. Educação escolar e cultura(s): construindo caminhos. In: Educação como exercício de diversidade. Brasília: UNESCO, MEC, ANPEd, 2005. 476 p. (Coleção Educação para todos; 6).

MARCCUSHI, L. A. Análise de conversação. São Paulo: Ática, 2005.

MARCELO GARCÍA, C. Formação de Professores: para uma mudança educativa. Trad. Isabel Narciso. Porto: Porto Editora, 1999. (Coleção Ciências da Educação século XXI).

MARCELO, C. Pesquisa sobre formação de professores: o conhecimento sobre aprender a ensinar. Revista Brasileira de Educação. São Paulo, n.9, p.51-75, set. / dez. 1998

MCCUTCHEON, G. Curriculum and the work of teachers. In: APPLE, M. W.; BEYER, L. The curriculum: problems, The curriculum politics, and possibilities. Nova York: Suny Press, 1988.

MIZUKAMI, M. G. N. Ensino: as abordagens do processo. São Paulo: EPU, 1986.

MORIN, E. Repensar a reforma, reformar o pensamento: a cabeça bem-feita. Lisboa: Instituto Piaget, 2002.

NISKIER, Arnaldo. Educação à Distância: a tecnologia da esperança. São Paulo: Loyola, 2000. 
NUNES, Andrea C.; TAVARES, Tais M.; TROJAN, Rose Meri. Análise da implantação da proposta curricular do curso de magistério de 2. grau da Secretaria de Educação, no período de 1990 a 1994. Curitiba: UFPR, 1995.

OLIVEIRA, Isolina. A reflexão e o professor como investigador.ia. fc.ul.pt/redeic/textos\%20teoria/02-oliveira-serras.doc.site,05-12-09.

OLIVEIRA, Gracilda Gomes. Gestão pedagógica: desafios e impasses. Dissertação (Dissertação de Mestrado em Educação) - Universidade Católica de Brasília. Brasília/DF 2007.

PACHECO, J. A. Escritos Curriculares. São Paulo: Cortez, 2005. . Uma perspectiva atual sobre a investigação em Estudos Curriculares. Disponível em http://www.periodicos.ufsc.br/index.php/perspectiva/article/viewFile/10760/10267. Acess 0 em: 20 de set de 2016.

PACHECO, J. A.; EVANGELISTA, M. O. Formação de Professores: perspectivas educacionais e curriculares; Orgs, Portugal: Porto, 2003.

PACHECO, J. A.; FLORES, M. A. Formação e avaliação de professores. Porto: Porto, 1999.

PACHECO, J. A.; MORGADO, J. C. Construção e avaliação do projeto curricular de escola. Portugal: Porto, 2002.

PAIVA, Vanilda Pereira. Educação Popular e Educação de Adultos: Contribuição à História da Educação Brasileira. São Paulo. Loyola. 1973.

PALMA, A. P. T. V.; PALMA, J. A. V. O ensino da Educação Física: princípios fundamentais para uma relação pedagógica construtivista na educação infantil e ensino fundamental. FIEP Bulletin, Foz do Iguaçu, v.75, n. esp., p. 91-94, 2005. PALMA, A. P. T. V; OLIVEIRA, A. A. B.; 
PALMA Ângela. P. T. V. e CESÁRIO, Marilene. Formação e desenvolvimento profissional docente: Profissionalização e Profissionalidade. Artigo publicado no FIEP BULLETIN, V. 77. Special Edition, 2007. p. 05-08.

PALMA, José. A. V. Projeto Integrado. Formação inicial e desenvolvimento profissional contínuo de professores: integrando possibilidades de pesquisa, ensino e extensão. Universidade Estadual de Londrina, 2005.

FREIRE, Paulo. Conscientização. Teoria e Prática da Libertação uma Introdução ao Pensamento de Paulo Freire. São Paulo: Morais, 1980

, Educação como Prática de Liberdade. Rio de Janeiro: Paz e Terra, 1994.

, Extensão ou Comunicação? Rio de Janeiro: Paz e Terra, 1975.

, Pedagogia da Autonomia: Saberes necessários à prática educativa. São Paulo: Paz e Terra, 1996.

PERRENOUD, P. Práticas pedagógicas, profissão docente e formação: perspectivas sociológicas. 2ª ed. Lisboa: Dom Quixote, 1997.

PIMENTA, S. G. A construção do projeto político pedagógico na escola de ensino fundamental. In. De professores, pesquisa e didática. Campinas: Papirus (2002).

PIMENTA, S. G. De professores, pesquisa e didática. Campinas: Papirus, 2002.

PIMENTA, S. G. Professor Reflexivo: construindo uma crítica. In Pimenta \& Ghedin (orgs.). Professor reflexivo no Brasil: gênese e crítica de um conceito. São Paulo: Cortez Ed, 2002. (1ª edição: junho de 2002; 2ª edição: novembro de 2002).

O estágio na formação de professores: unidade teoria e prática?6 ed. São Paulo: Cortez, 2005 RIBEIRO. A. C. Desenvolvimento curricular. LISBOA, 7ํㅜㅇ ED, 1998. 
PORLÁN, A et al. Conocimiento profesional y epistemología de los profesores I: Teoría, métodos e instrumentos. Enseñanza de las ciencias. 15(2): 155-171, 1997.

RICHARDSON, R. Pesquisa social: métodos e técnicas. 3. ed. São Paulo: Atlas, 1999.

RIBEIRO, D. Aos trancos e Barrancos. Como no Brasil deu no que deu. Rio de Janeiro; Guanabara-Koogan. 1998.

ROGERS, C. (1991). Tornar-se pessoa. São Paulo: Martins Fontes.

ROGERS, C. (1980). Duas tendências divergentes. Em: May, R. (Org.). Psicologia existencial. Porto Alegre: Ed. Globo.

ROGERS, C. \& Stevens, B. (1992). De pessoa para pessoa. São Paulo: Pioneira.

RUIZ, A. R.; BELLINI, L. M. Interdisciplinaridade e epistemologia uma leitura pela "ótica" piagetiana.In. Ensino e conhecimento: elementos para uma pedagogia em ação. Uel: Londrina, 1998.

SANTOS, R. V. Abordagens do processo de ensino aprendizagens. Integração. Jan./ 180 fev. /maio. 2005. Ano XI, no 40. 19-31.

. Pedagogia Histórico-crítica: primeiras aproximações. 3. ed. São Paulo: Cortez; Autores Associados, 1992.

SAVIANI, Dermeval. Tendências e correntes da educação brasileira. In: MENOES, D. T. (coord.). Filosofia da Educação Brasileira. $2^{\underline{a}}$ ed. Rio de Janeiro: CIVILIZAÇÃO BRASILEIRA, 1985.

SAVIANI, Dermeval. Escola e democracia: teorias da educação, curvatura da vara, onze teses sobre educação e política. São Paulo, Cortez, Autores Associados. 1986.

SAVIANI, Dermeval. As concepções pedagógicas na história da educação brasileira. Campinas, 2005. 
SHÖN. A. D. Educando o profissional reflexivo: um novo design para o ensino e aprendizagem. São Paulo - SP: Artmed,1998.

SILVA, E. V. M. e; VENÂNCIO, L. Aspectos legais da educação física e integração à proposta pedagógica da escola. IN: DARIDO, Suraya Cristina; RANGEL, I. C. A. (coord). Educação física na escola: implicações para a prática pedagógica. Rio de Janeiro: Guanabara Koogan, 2005. p. 50-61. (Coleção Educação Física no Ensino Superior).

SILVA, Waldeck C. da, (1999). A criação dos institutos superiores de educação no Brasil: alternativa superior para a formação de professores?

SILVA, J. N. A formação de contínua de professores: contradição de um modelo. In: MORAES, M. C. PACHECO, J. A. EVANGELISTA, M. O. Formação de professores: perspectivas. Educacionais e curriculares. Porto: Editora: Porto, 2003.

SOARES, C. L. et al. Metodologia do Ensino da Educação Física. São Paulo: Cortez, 1992.

SKINNER, Burrrhus Frederic. (1972). Tecnologia do ensino. (Rodolpho Azzi, Trad.). São Paulo: Herder, Ed. da universidade São Paulo, 1972.

. Ciências e comportamento humano. São Paulo: Martins Fontes, 2003.

Teorias de aprendizagem são necessárias? Rev. Brasileira de Análise do Comportamento. Vol. 1, oㅜ1, 2005.

TANURI, L. M. História da formação de professores. Revista Brasileira de Educação, n. 14, maio-agosto 2000, p. 61-88.

TARDIFF, M. Saberes Docentes e Formação Profissional - O trabalho docente, a pedagogia e o ensino. Petrópolis, Vozes, 2002. 
TEIXEIRA, Anísio Spínola. A Crise Educacional Brasileira (1953). In: Conselho Estadual de Educação (São Paulo - SP) A Voz dos Educadores - Textos Escolhidos. Estudos e Normas nำ7 - Conselho Estadual de Educação, SP. CEE, 2002.

VASCONCELOS, M. L. M. C. A Formação do professor do Ensino Superior. 2a . ed. São Paulo: Editora Pioneira. 2000.

VILELA, Heloisa de Oliveira. A Primeira Escola Normal do Brasil: Concepções sobre a Institucionalizações da Formação Docente no século XIX. Campinas SP. Editora: Alínea. 2008

VYGOTSKY, Lev Semyonovitch. Pensamento e Linguagem. São Paulo: Martins Fontes, 1998.

Aprendizagem e desenvolvimento intelectual na idade escolar. In: VYGOTSKY, Lev Semyonovitch, LURIA, Alexander Romanovitch, LEONTIEV, Aleksei Nikolaievitch. Linguagem, desenvolvimento e aprendizagem. São Paulo: Ícone, 2001. 46

Formação social da mente: o desenvolvimento dos processos psicológicos superiores. 7 ed. São Paulo: Martins Fontes, 2007.

WAJSKOP, Gisela. Brincar na pré-escola. 7. Ed. São Paulo: Cortez, 2007

Watson-Gegeo, K. A. Heavy words and important silences: the social transfer of cognitive skills in Kwara'ae. Paper presented at the third international conference on thinking, Honolulu, January, 1987.

Watson, John B. «Psychology as the behaviorist views it» Psychological Review. 20 (2): 158-177. doi:10.1037/h0074428

WIELEWICKI, V. H. G. A pesquisa etnográfica como construção discursiva.

Scientiarum (UEM), Maringá, v.23, n. 1, p. 27-32, 2001. 
1. As Cartas Jesuíticas são documentos apresentados sob a forma de cartas escritas pelos padres jesuítas e que tinham como objetivo fornecer um relato das atividades desenvolvidas pela Companhia nas terras descobertas.

2. A Imprensa Régia, única tipografia existente no Rio de Janeiro até a independência, além de imprimir a legislação produzida, fabricar livros em branco para escrituração, encadernar impressos e prover todas as necessidades do ofício de livreiro, também editava livros.

3. O Brasil Imperial foi um período da História brasileira ocorrido entre 7 de setembro de 1822 (Independência do Brasil) e 15 de novembro de 1889 (Proclamação da República. Nesse período, o Brasil foi governado por dois monarcas: D. Pedro I e D. Pedro II.

4. A ABE era uma sociedade civil, de adesão voluntária, que reunia professores e interessados em educação.

5. Estado Novo, ou Terceira República Brasileira, foi o regime político brasileiro fundado por Getúlio Vargas em 10 de novembro de 1937, que vigorou até 31 de janeiro de 1946. Era caracterizado pela centralização do poder, nacionalismo, anticomunismo e por seu autoritarismo.

6. Getúlio Dornelles Vargas foi um advogado e político brasileiro, líder civil da Revolução de 1930, que pôs fim à República Velha, depondo seu $13^{\circ} \mathrm{e}$ último presidente, Washington Luís, e, impedindo a posse do presidente eleito em 1 de março de 1930, Júlio Prestes.

7. Regime Militar no Brasil: Regime Militar de 1964, o golpe militar de 64, Governos Militares, Governo Castello Branco, Governo Costa e Silva, Governo da Junta Militar, Governo Médici, AI-5, Governo Geisel, Governo Figueiredo, Redemocratização, Lei da Anistia, Diretas Já.

8. Entende-se infraestrutura como os modos e os meios do homem produzir sua existência. Neste sentido as transformações, desses processos, devem ser compreendidas como alavancas que pressionam a ocorrência de mudanças na superestrutura que, por sua vez se movimenta entre dois elementos: as instituições e as ideias. 
9. Abordagem é o termo utilizado para caracterizar um tipo de aproximação, seja entre pessoas ou coisas. Normalmente, a abordagem é o modo como determinada pessoa se aproxima de outra.

10. Prática pedagógica: atividade pedagógica planejada e colocada em ação.

11. Tendências: As tendências pedagógicas são de extrema relevância para a Educação, principalmente as mais recentes, pois contribuem para a condução de um trabalho docente mais consciente.

12. Jonh B. Watson foi o fundador do movimento comportamentalista na psicologia, definindo-a como a ciência do comportamento, sendo este um ramo objetivo e experimental das ciências naturais. Ao enquadrar a psicologia como um ramo das ciências naturais, Watson considera a existência na continuidade entre o animal e o homem. Para os comportamentalistas, embora haja um maior requinte e complexidade no comportamento do homem em relação ao comportamento animal, ambos podem ser explicados pelos mesmos princípios. Desta forma, o objeto de pesquisa do comportamentalismo é o comportamento, humano e animal.

13. Currículo: são as Diretrizes colocadas pelo Conselho Nacional de Educação CNE trata-se da "reflexão" sistemática sobre o saber do fazer de cada professor e da escola como um todo é impulsionadora do processo de produção do conhecimento que se instaura como uma atividade crítica desde as origens da formação do professor" (Princípio VI).

14. Bernadete Angelina Gatti ingressou na APE em 20 de agosto de 2007, saudada por João Gualberto de Carvalho Meneses. Atual membro da cadeira de número 27 da Academia Paulista de Educação, a professora Bernadete Angelina Gatti nasceu em 3 de maio de 1941, em Matão, São Paulo. Doutora em Psicologia pela Université de Paris VII e pós-doutorado pela Pennsylvania State University (EUA) e pela Université de Montreal (Canadá). Atualmente, é pesquisadora sênior e coordenadora do Departamento de Pesquisas Educacionais da Fundação Carlos Chagas.

15. Concepções: A expressão "concepções pedagógicas" é correlata de "ideias pedagógicas". A palavra pedagogia e, mais particularmente, o adjetivo pedagógico têm marcadamente ressonância metodológica denotando o modo 
de operar, de realizar o ato educativo. Assim, as ideias pedagógicas são as ideias educacionais entendidas, porém, não em si mesmas, mas na forma como se encarnam no movimento real da educação orientando e, mais do que isso, constituindo a própria substância da prática educativa.

16. Operacionalizar: verbotransitivo direto tornar operacional. Preparar, treinar para realizar uma função; tornar apto para concluir uma tarefa. Tornar alguém apto para a realização de uma função, trabalho ou para finalização de uma atividade, tarefa: operacionalizar a produção.

17. Prova Brasil: avaliação realizada pelo MEC, nos estabelecimentos de ensino fundamental e médio.

18. Intervenção: é o substantivo feminino que significa o ato ou efeito de intervir e indica uma intercessão ou mediação em alguma situação adversa.

19. A semana pedagógica aqui no caso se trata dos momentos previstos no calendário letivo da rede Municipal de Educação de Aquiraz, que tem como propósito possibilitar aos professores uma formação continuada.

20. Observações: Observação é o ato de observar, isso significa ter a atenção direcionada para algo específico, com o intuito de posteriormente julgar, analisar ou investigar determinada coisa ou alguém. No âmbito científico, ela faz parte do método científico, consistindo unicamente em observar e perceber o objeto-alvo.

21. Questionários: Um questionário é um conjunto de perguntas que se faz para obter informação com algum objetivo em concreto. Existem diversos estilos e formatos de questionários, dependendo da finalidade específica de cada um. 


\section{ANEXOS}

\section{FOTOS DE EVENTOS OCORRIDOS NO MUNICÍPIO NO ANO DE 2016}

Formação De Professores

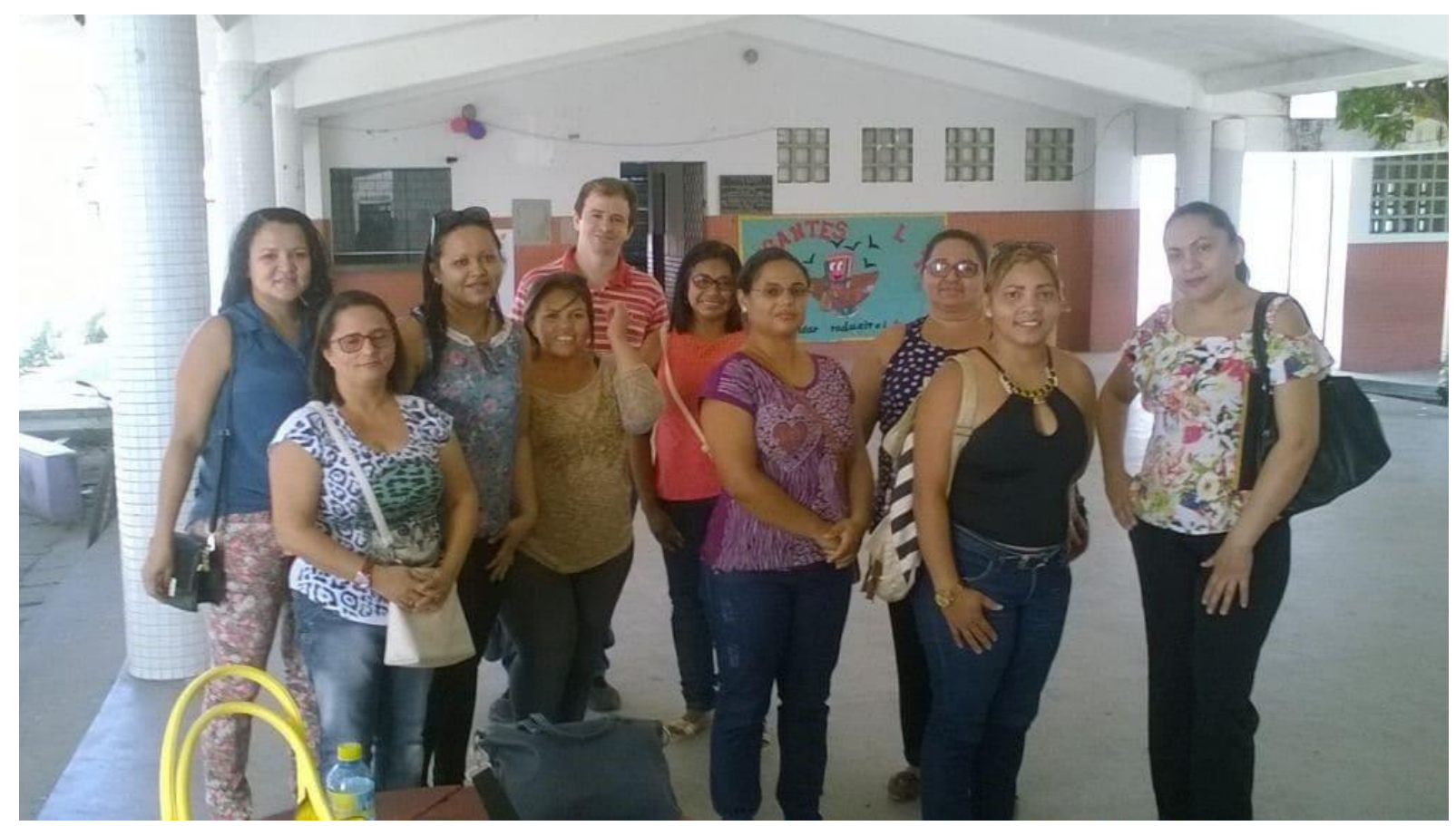

Fonte: Autor. 
Apresentação do grupo de flautas

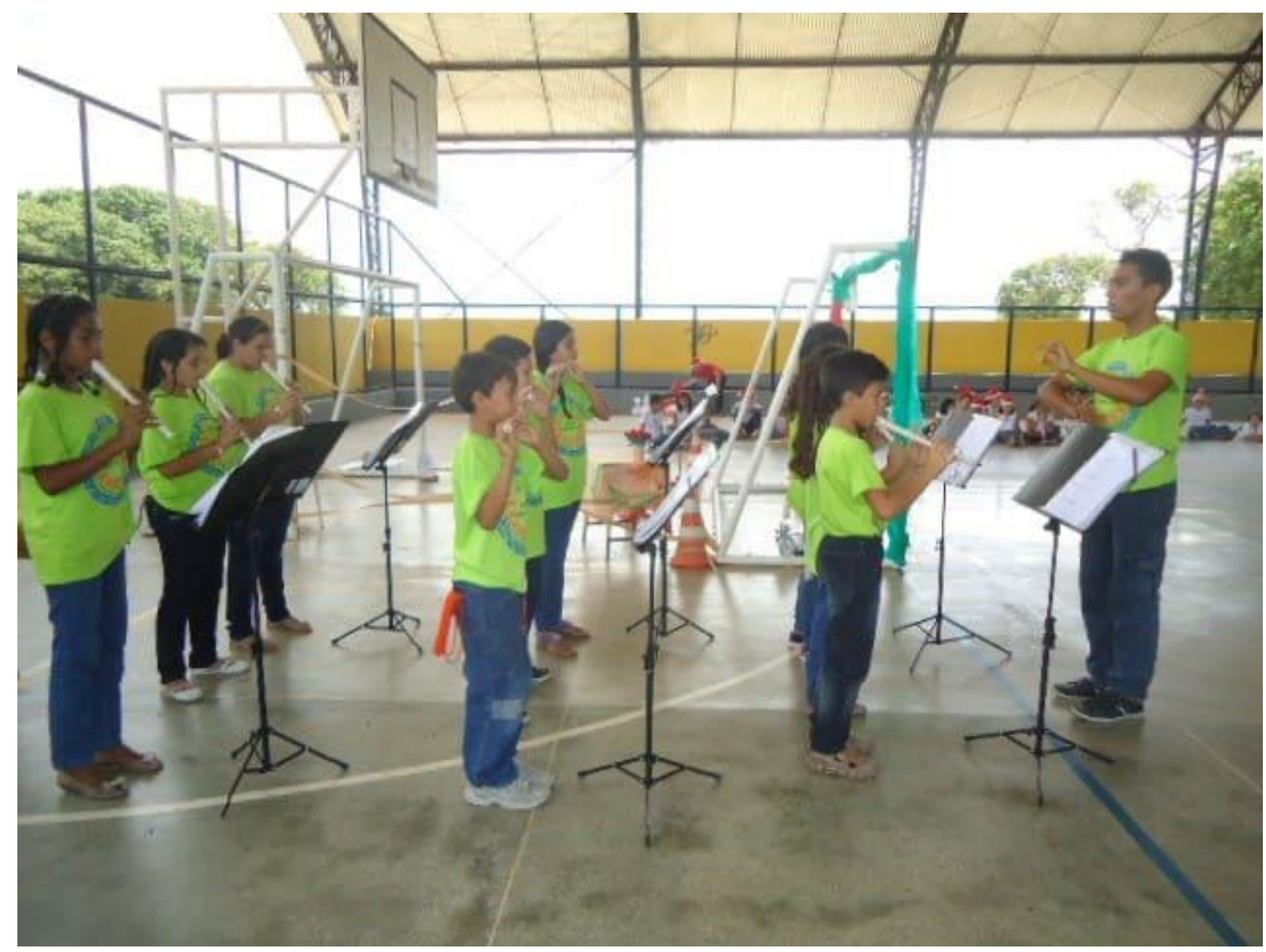

Fonte: Autor. 
Apresentação do grupo de violão

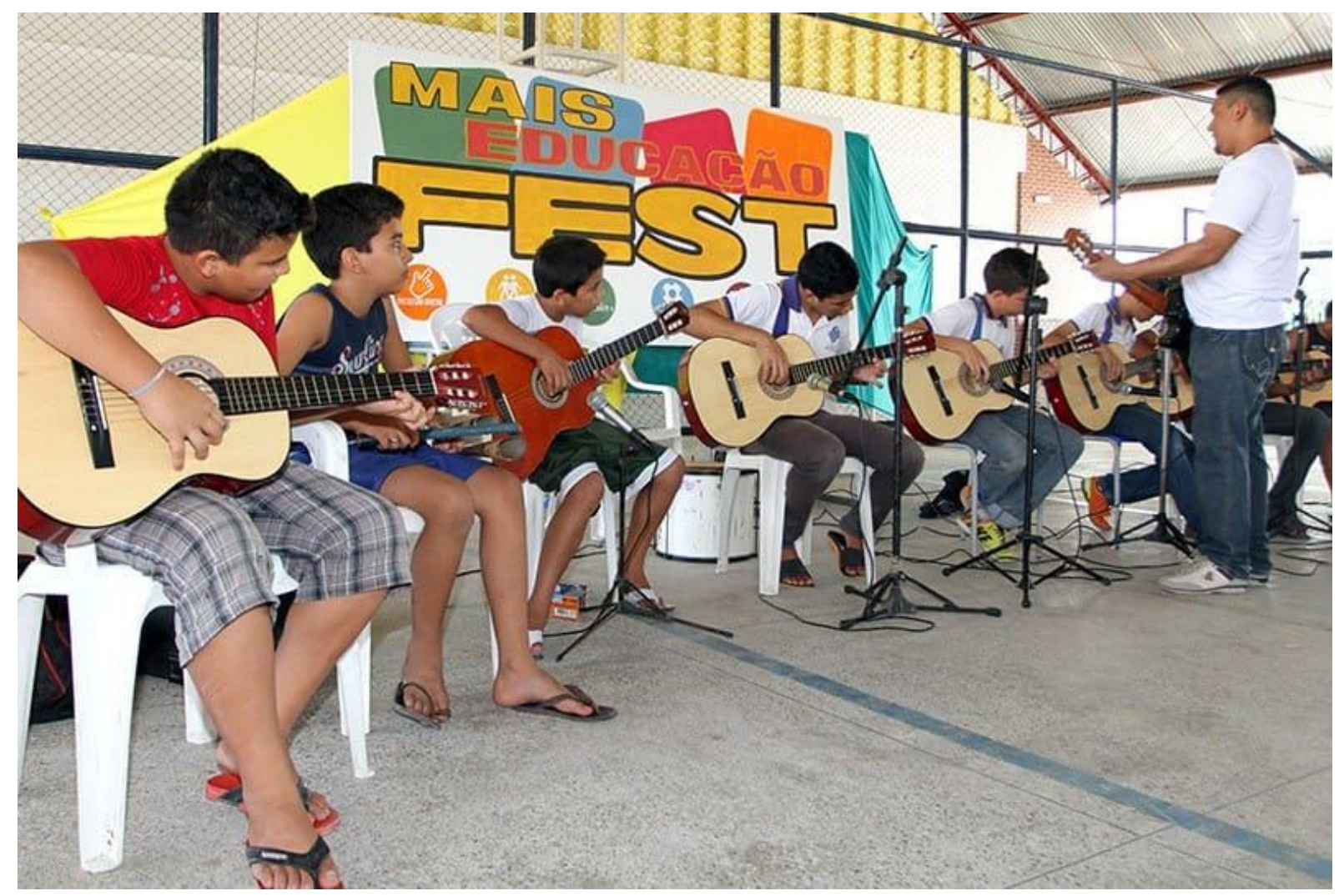

Fonte: Autor. 
Jogos escolares

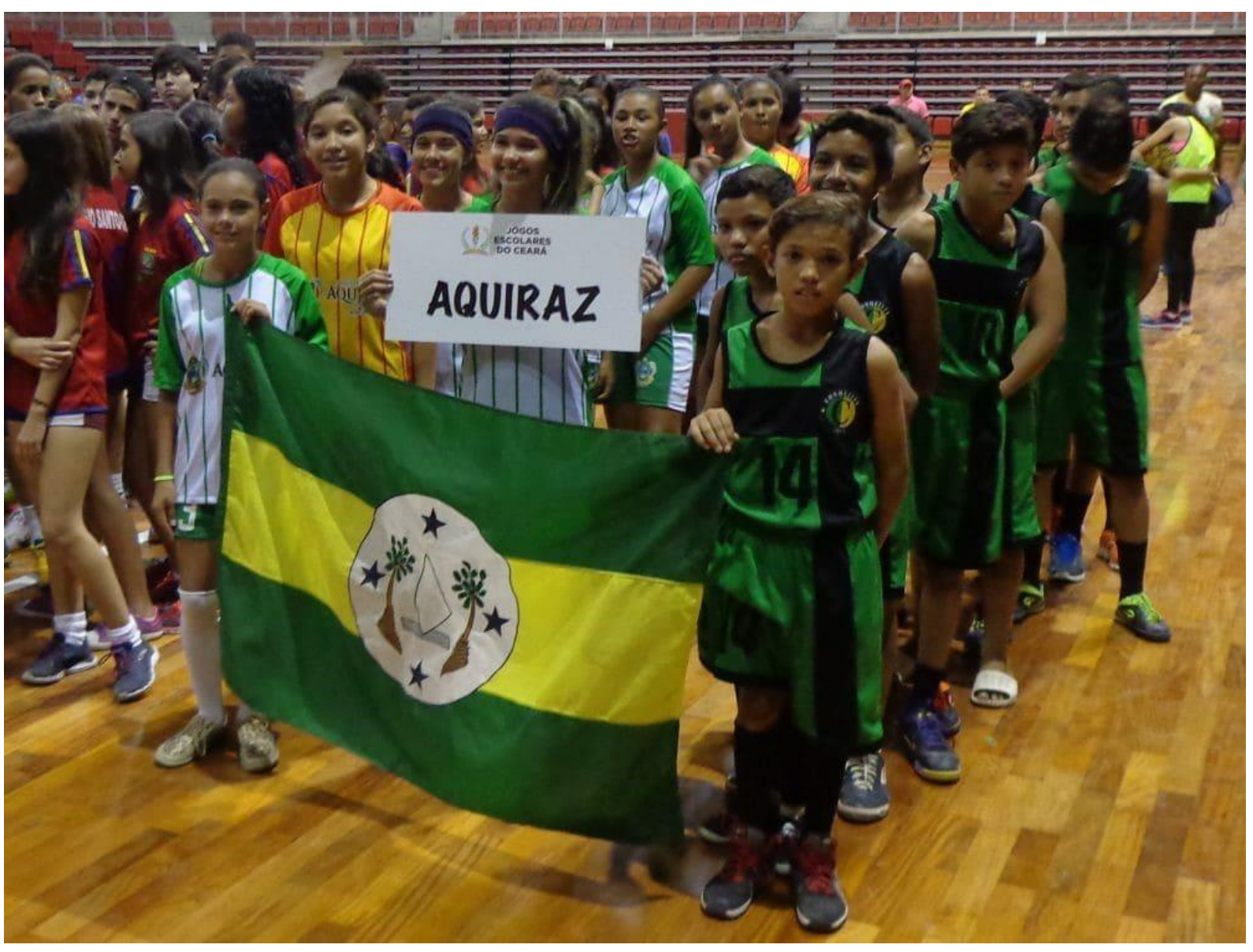

Fonte: Autor. 
Membros da secretaria de educação e desporto

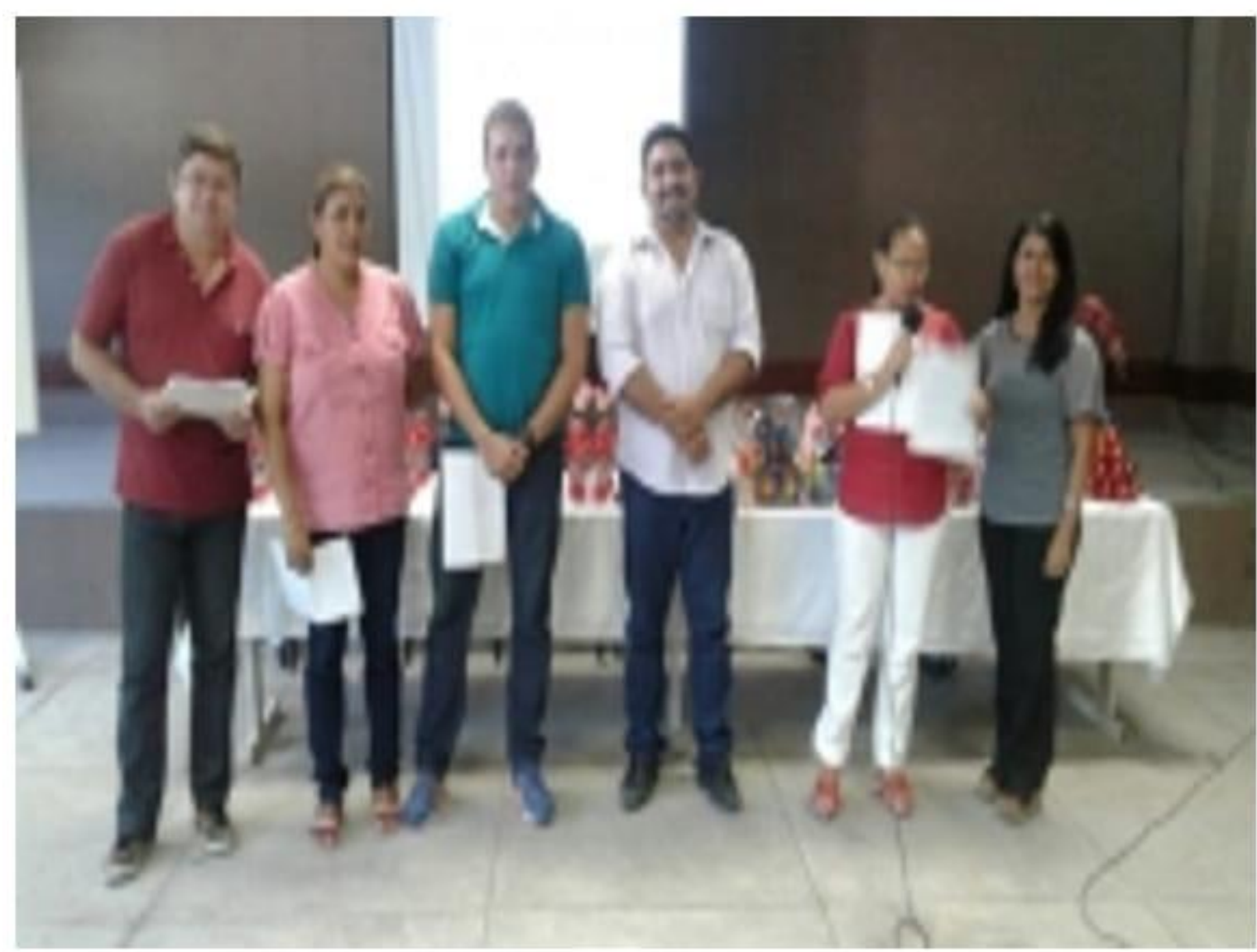

Fonte: Autor. 
Preocupação com autista de educação especial

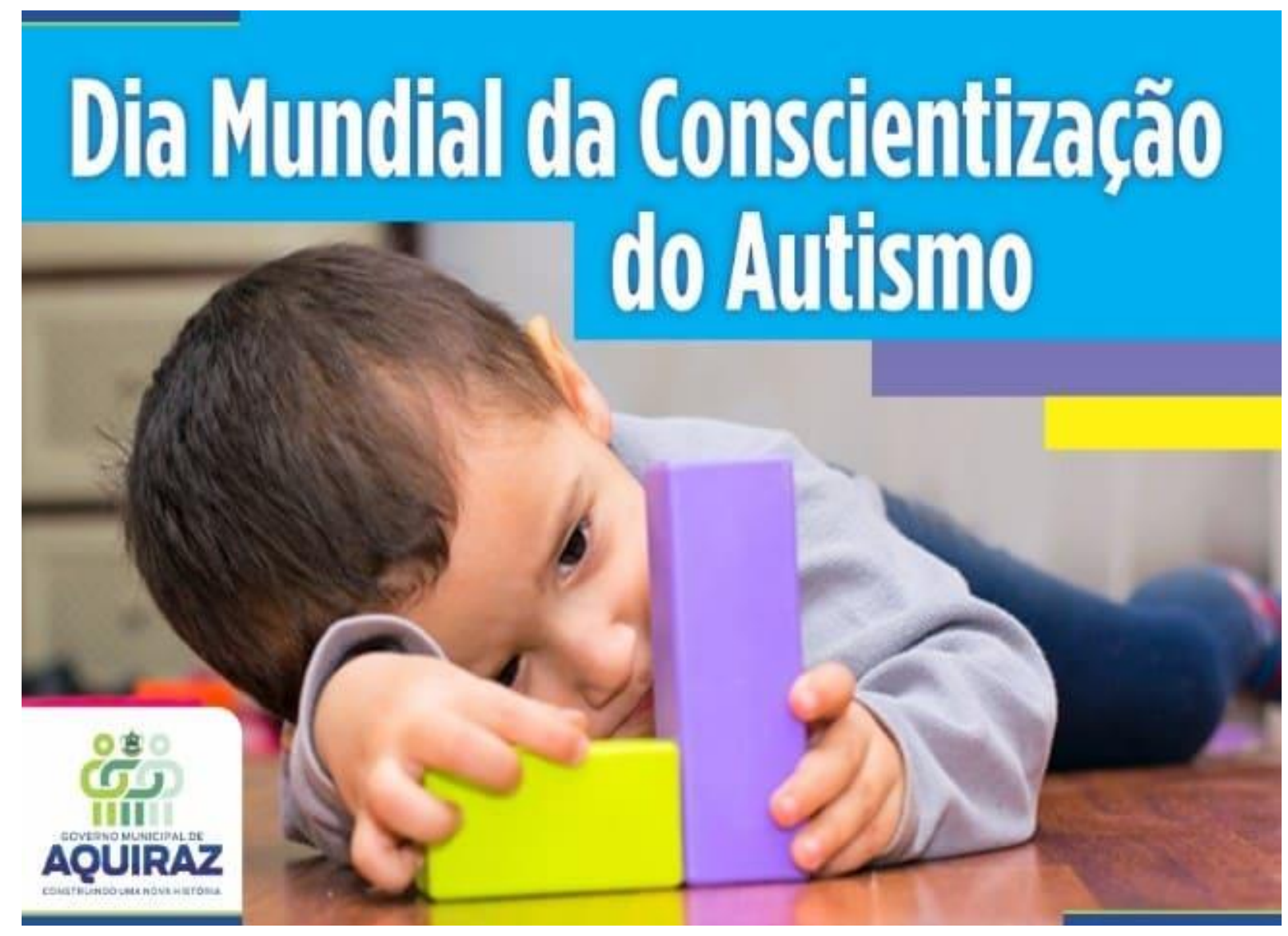

Fonte: Autor. 


\section{CONSULTORIA EM TURISMO PEDAGÓGICO}

\section{Escolas visitam museu de aquiraz}

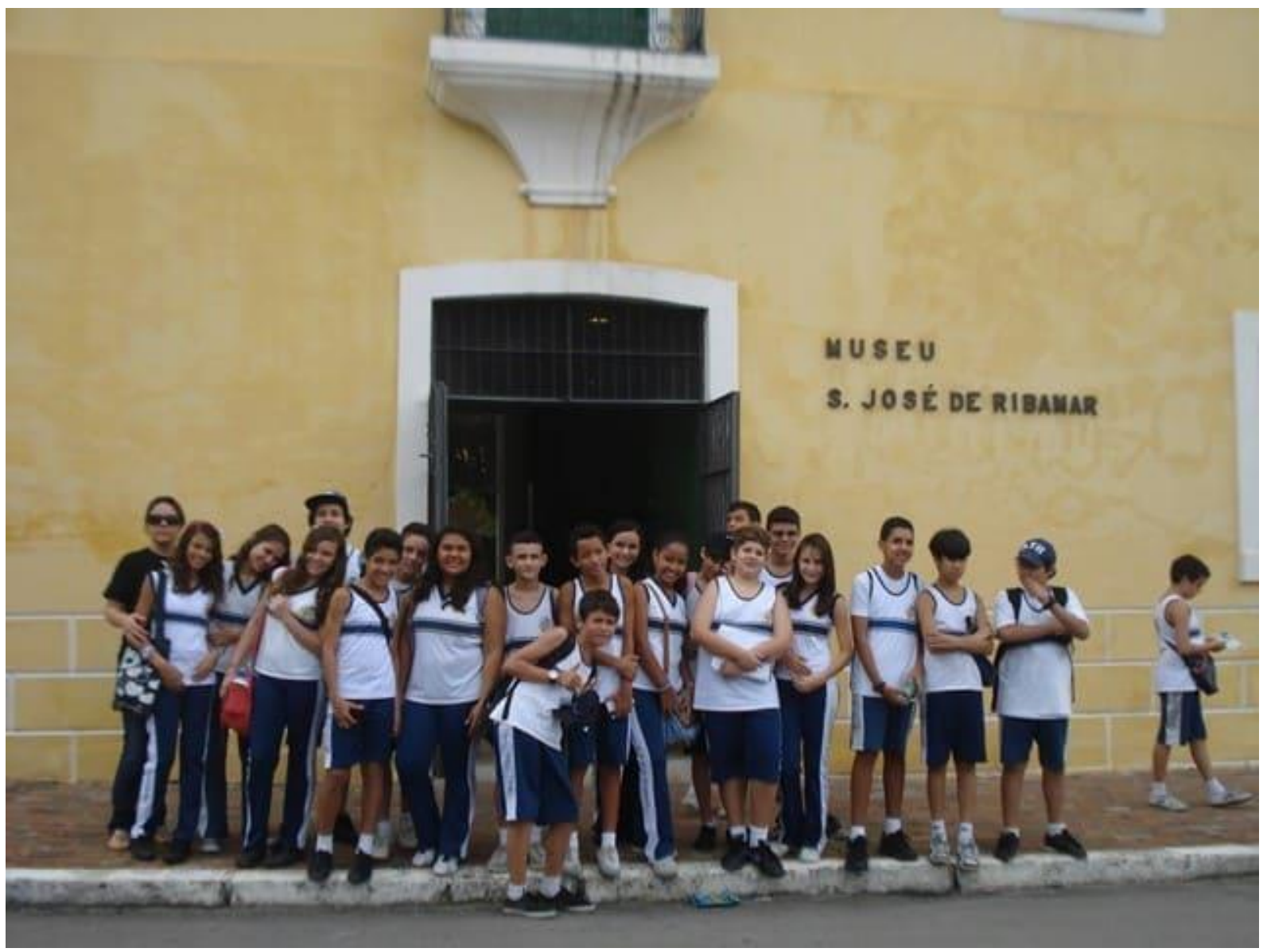

Fonte: Autor. 


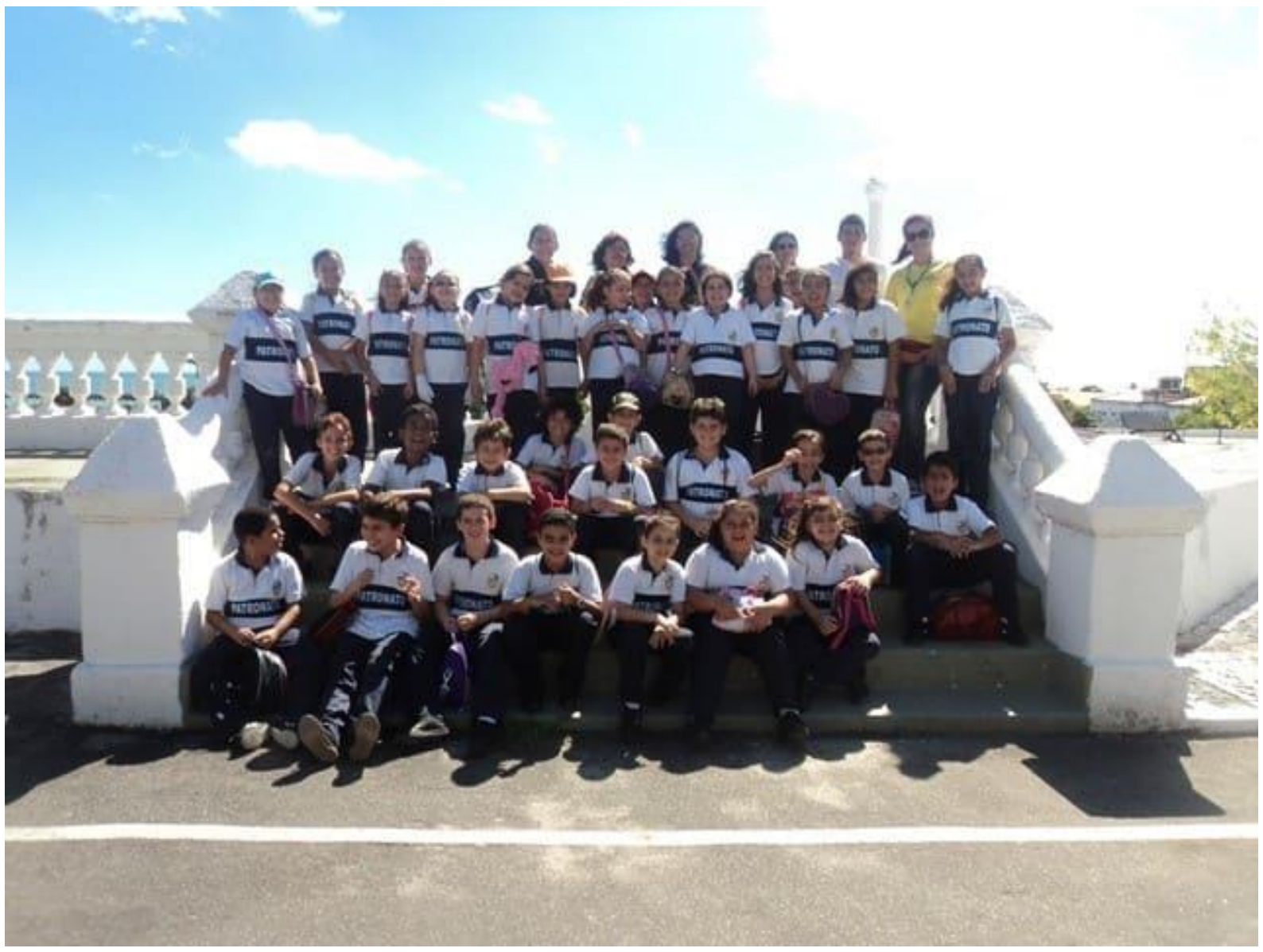

Fonte: Autor. 
Celebrando a cultura nordestina

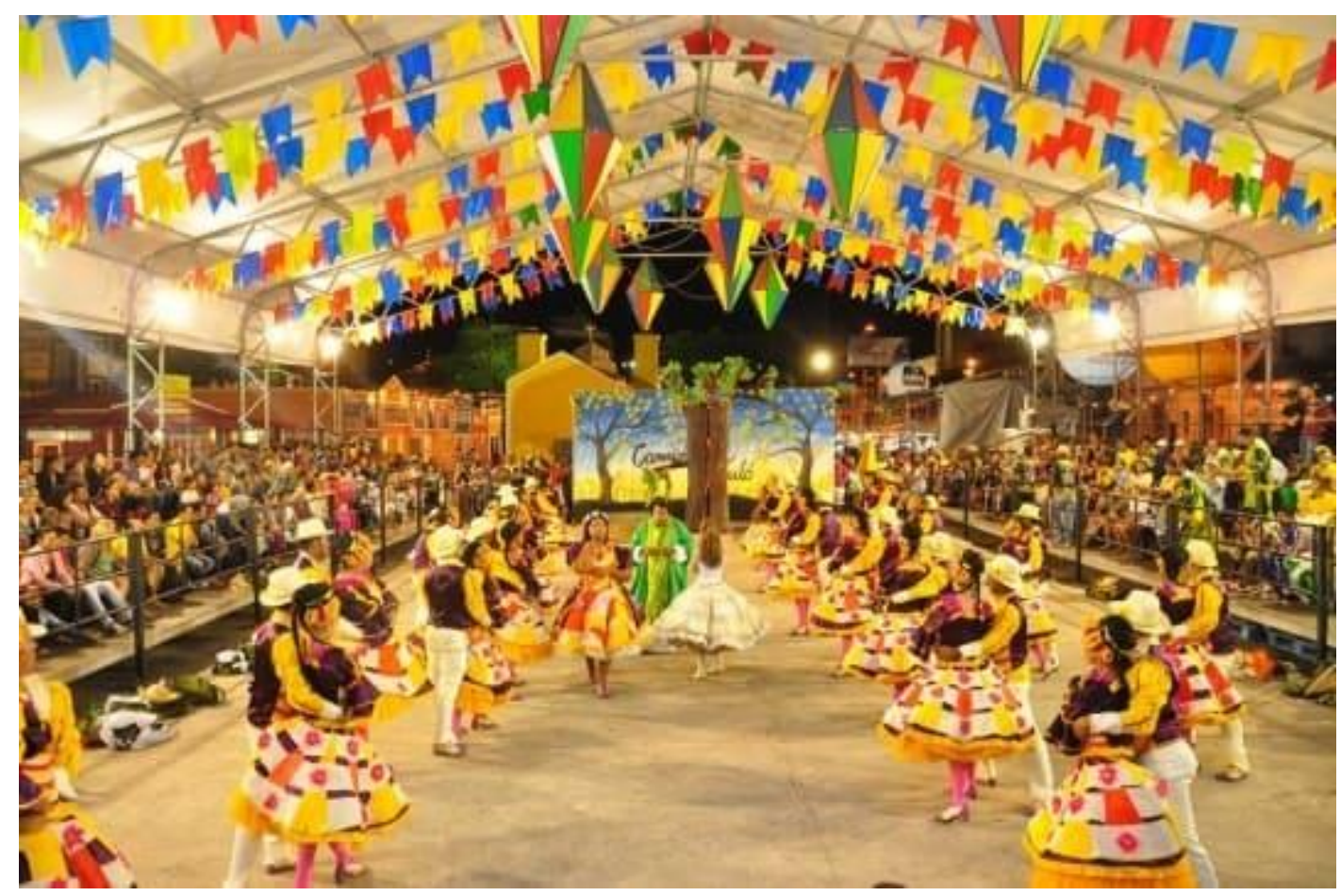

Fonte: Autor.

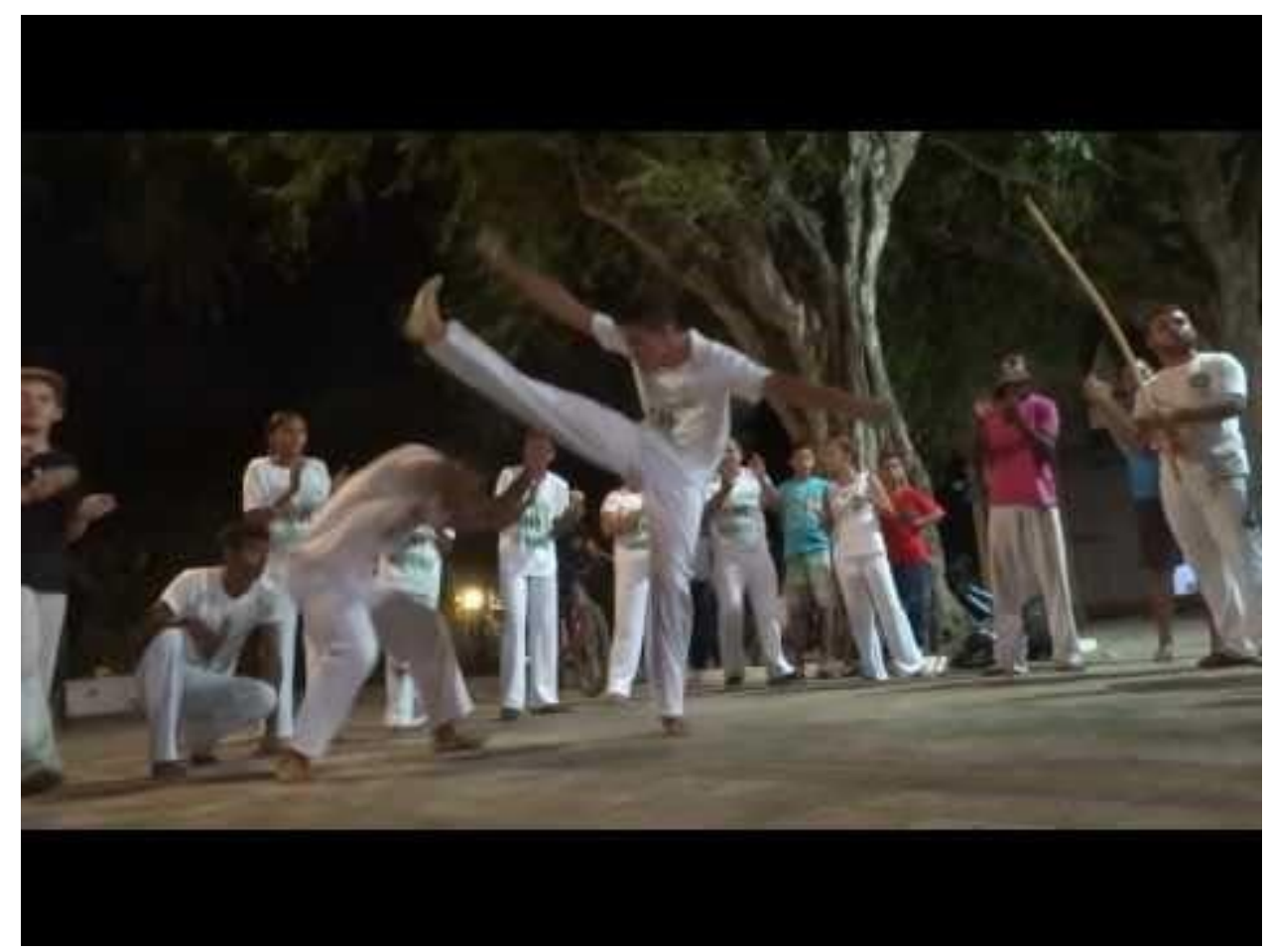

Fonte: Autor.

RC: 32396

Disponível em: https://www.nucleodoconhecimento.com.br/pedagogia/praticas-pedagogicas 
Enviado: Março, 2018.

Aprovado: Maio, 2019. 